\title{
Archaeological Investigations of Sections of the San Pedro (41BX337) and Upper Labor (41BX1273) Acequias in San Antonio, Bexar County, Texas
}

Sarah Wigley

Center for Archeological Research, University of Texas at San Antonio

Follow this and additional works at: https://scholarworks.sfasu.edu/ita

Part of the American Material Culture Commons, Archaeological Anthropology Commons, Environmental Studies Commons, Other American Studies Commons, Other Arts and Humanities Commons, Other History of Art, Architecture, and Archaeology Commons, and the United States History Commons

Tell us how this article helped you.

This Article is brought to you for free and open access by the Center for Regional Heritage Research at SFA ScholarWorks. It has been accepted for inclusion in Index of Texas Archaeology: Open Access Gray Literature from the Lone Star State by an authorized editor of SFA ScholarWorks. For more information, please contact cdsscholarworks@sfasu.edu. 
Archaeological Investigations of Sections of the San Pedro (41BX337) and Upper Labor (41BX1273) Acequias in San Antonio, Bexar County, Texas

\section{Creative Commons License}

\section{(c) (1) \&}

This work is licensed under a Creative Commons Attribution-NonCommercial 4.0 International License 
Archaeological Investigations of Sections of the San Pedro (41BX337) and Upper Labor (41BX1273) Acequias in San Antonio, Bexar County, Texas

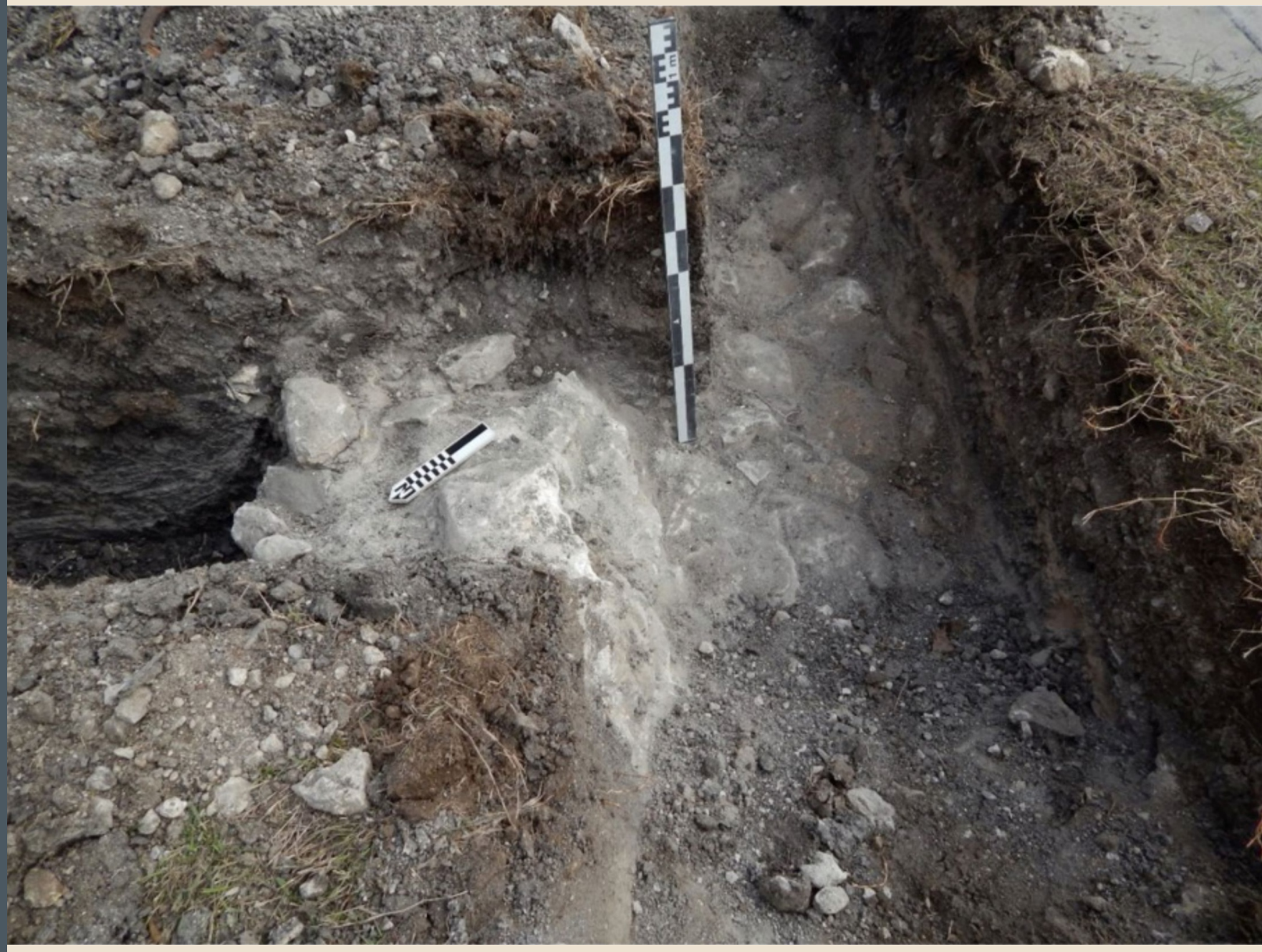

by

Sarah Wigley

Texas Antiquities Permit No. 9229

Prepared for:

VIA Metropolitan Transit 1720 North Flores Street San Antonio, Texas 78212

\section{REDACTED}

Principal Investigator

Raymond Mauldin

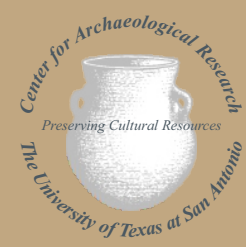

Prepared by:

Center for Archaeological Research The University of Texas at San Antonio One UTSA Circle

San Antonio, Texas 78249

Archaeological Report, No. 481 



\section{Archaeological Investigations of Sections of the San Pedro (41BX337) and Upper Labor (41BX1273) Acequias in San Antonio, Bexar County, Texas \\ by \\ Sarah Wigley}

REDACTED

Texas Antiquities Permit No. 9229

Principal Investigator

Raymond Mauldin

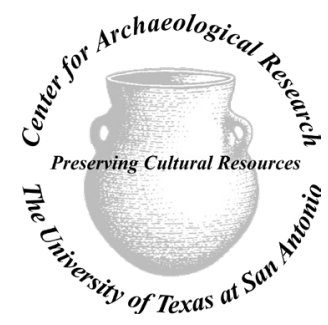

Prepared for:

VIA Metropolitan Transit Authority

1720 North Flores Street

San Antonio, Texas 78212
Prepared by:

Center for Archaeological Research The University of Texas at San Antonio One UTSA Circle

San Antonio, Texas 78249

Archaeological Report, No. 481

(C) May 2020 



\section{Abstract:}

On January 21 and February 19 of 2020, the Center for Archaeological Research (CAR) excavated five exploratory backhoe trenches within two project areas in central San Antonio, Bexar County, Texas. Project Area 1 is located at 209 E. Fredericksburg Road, and Project Area 2 is at 712 W. Laurel Street. CAR was contracted by the VIA Metropolitan Transit Authority (VIAMTA) to conduct an archaeological investigation of the two locations as they planned to use the areas for employee parking lots. Plans called for the areas to be excavated to a total depth of $25.4 \mathrm{~cm}(10 \mathrm{in}$.), with $15.24 \mathrm{~cm}(6 \mathrm{in}$.) of new concrete and $10.16 \mathrm{~cm}$ (4 in.) of new base. Archival maps suggested that the proposed parking areas could include the intersection of two Spanish Colonial acequias, the San Pedro (41BX337) and the Upper Labor (41BX1273). Both areas are owned by VIA-MTA, a political subdivision of the State of Texas. As such, the work was carried out under Texas Antiquities Permit No. 9229 according to the requirements of the Texas Antiquities Code and the Unified Development Code of the City of San Antonio (COSA). Dr. Raymond Mauldin served as the Principal Investigator, and Sarah Wigley served as the Project Archaeologist.

Five backhoe trenches were excavated in the two project areas. Three trenches were excavated in Project Area 1 and encompassed 0.024 ha $(0.06$ ac.). Two trenches were excavated within Project Area 2 and encompassed 0.089 ha (0.22 ac.). Four features were documented. Feature 1 was identified as a section of the Upper Labor Acequia (41BX1273), and Feature 3 was identified as a section of the San Pedro Acequia (41BX337). Feature 2 was a late construction dump and was found not to be significant. Feature 4 was documented within the channel of Feature 3 and is also part of 41BX337. The San Pedro Acequia (41BX337) has previously been found to be eligible for the National Register of Historic Places (NRHP) and is also eligible for designation as a State Antiquities Landmark (SAL). The Upper Labor Acequia (41BX1273) has been previously recommended as eligible for the NRHP and for designation as a SAL. The acequia is also a contributing resource to Brackenridge Park's NRHP nomination (National Park Service 2011). Both sites are a part of the San Antonio's acequia system, which is a designated National Historic Civil Engineering Landmark. CAR recommends that the section of the San Pedro Acequia (41BX337) and the section of the Upper Labor Acequia (41BX1273) documented during the course of this project are eligible for inclusion to the NRHP and for designation as a SAL. However, neither of these sites should be impacted by the proposed parking lot construction that has a maximum depth of impact of $25.4 \mathrm{~cm}$ (10 in.), which is a depth above the features. As such, CAR recommends that the construction of both parking areas be allowed to proceed, though with an archaeological monitor present. CAR further recommends that should buried cultural features be encountered during construction work in the immediate area cease and that the Texas Historic Commission (THC) and the COSA Office of Historic Preservation (COSA-OHP) be notified to consult on additional actions that may be necessary to protect the cultural remains. Both the THC and COSA-OHP concurred with the recommendations. However, prior to the issuance of the concurrence documents from the THC, VIA-MTA paved Project Area 2 (712 W. Laurel Street) without notifying CAR. No monitor was present for the excavation or paving. CAR subsequently photographed the area. In addition, VIA-MTA no longer plans to do any work in Project Area 1.

No artifacts were collected from Project Area 1, but several historic artifacts were collected from Project Area 2. These artifacts along with all records generated on this project are curated at the CAR facility as accession 2259. 
This page intentionally left blank. 


\section{Table of Contents:}

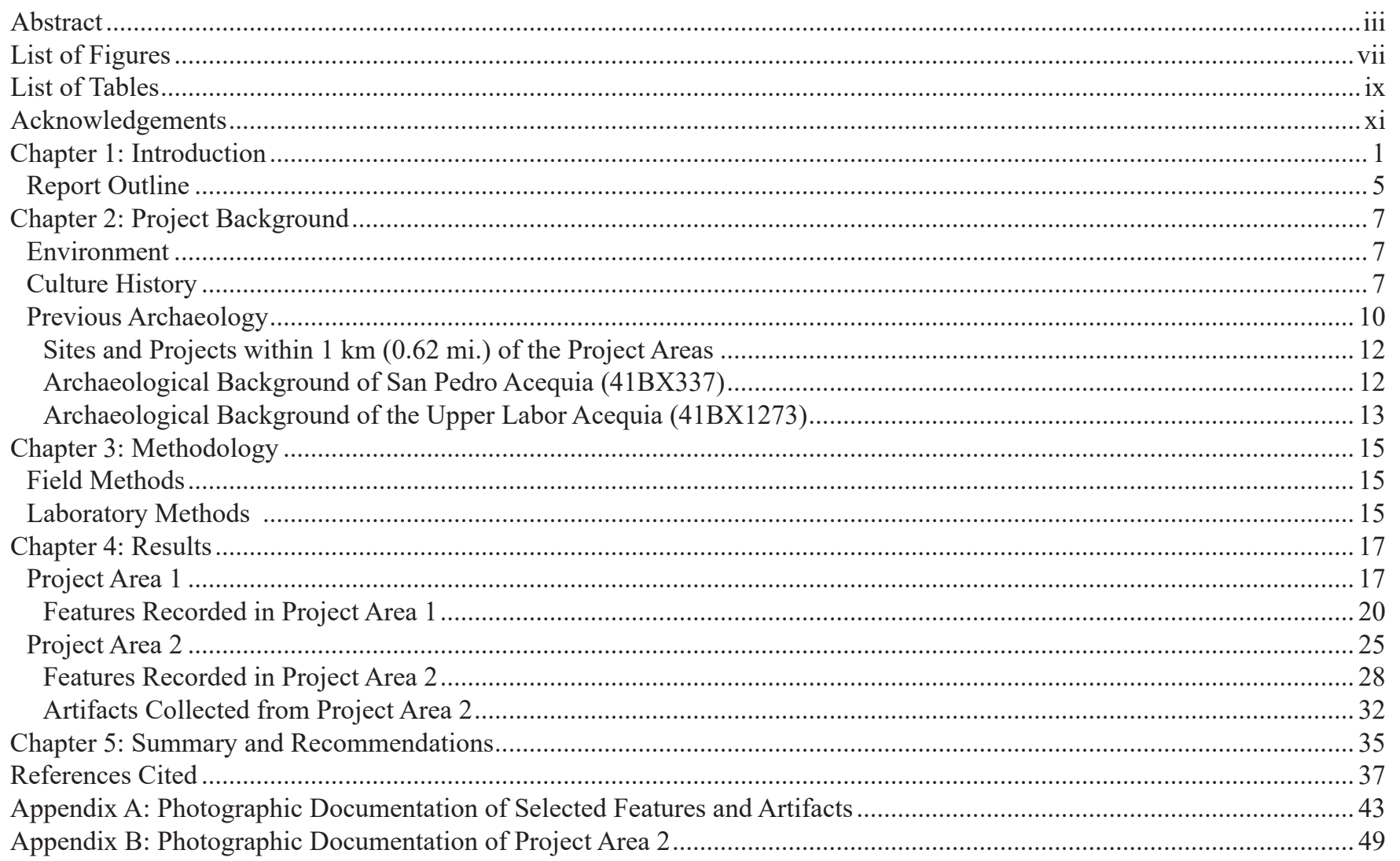


This page intentionally left blank. 


\section{List of Figures:}

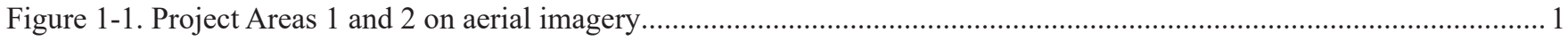

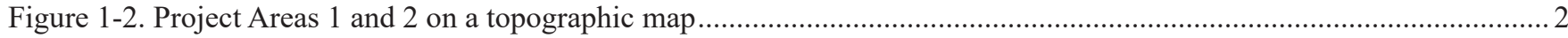

Figure 1-3. Project Areas 1 and 2 on the 1904 Sanborn Fire Insurance Map (Sanborn 1904). Note that the map terminates

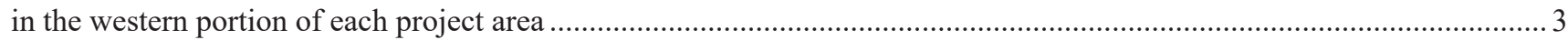

Figure 1-4. Project Areas 1 and 2 on the 1911 Sanborn Fire Insurance Map (Sanborn 1911) ................................................ 4

Figure 2-1. Project Areas 1 and 2 overlain on the Freisleben 1875 map (Freisleben 1875). Note the intersection of the San Pedro (north-south) and the Upper Labor (east-west) acequias..

Figure 2-2. Project Areas 1 and 2 overlain on an 1877 plat map (Bexar County Deed Records V6:565). Note the intersection of the San Pedro and Upper Labor acequias .

Figure 2-3. Previous archaeology, including the location of acequias

Figure 2-4. Projected location of the acequias as blue lines. The dots identify locations near the project area where sections of the San Pedro Acequia were previously documented by the CAR. Locations are georeferenced based on

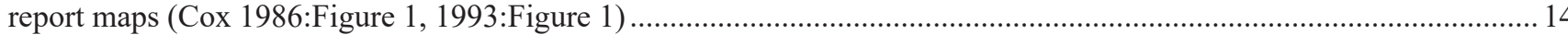

Figure 3-1. Trench locations on the 1911 Sanborn Fire Insurance Map (Sanborn 1911) .................................................. 16

Figure 4-1. Project Area 1, prior to excavation. Facing east. Area is defined by the chain-link fence on the north and

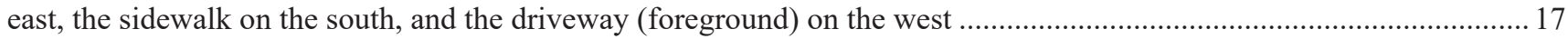

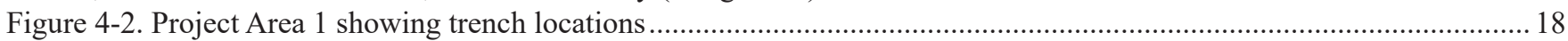

Figure 4-3. Gas line marking west of BHT 1 (facing west); north-south alignment marked in yellow spray paint ................. 19

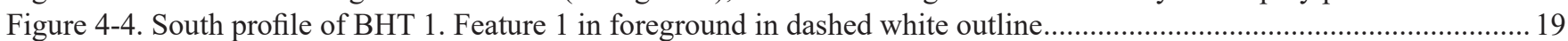

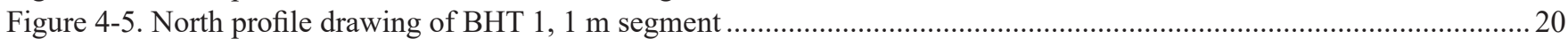

Figure 4-6. East profile of BHT 2. Feature 2 (left) demarcated by dashed white outline.................................................... 21

Figure 4-7. East profile of BHT 2, $1 \mathrm{~m}$ segment. Roots are shown as yellow lines ........................................................2 21

Figure 4-8. Trench and feature locations within Project Area 1 ...........................................................................22

Figure 4-9. Feature 1 facing west. Wall to the right and cobble floor to the left .............................................................23

Figure 4-10. Feature 1 facing east. Wall to the left and cobble floor to the right .............................................................23

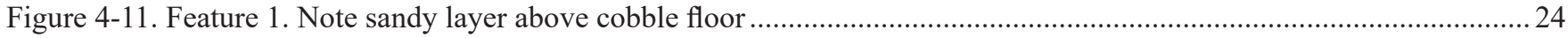

Figure 4-12. Northern profile of Feature 1 within BHT 3 (facing south). Note partial wall collapse ...................................24

Figure 4-13. Project Area 2, prior to excavation (facing west). Southern property boundary is the chain-link fence with the western boundary defined by the structure and northern boundary inside the utility poles ............................... 25

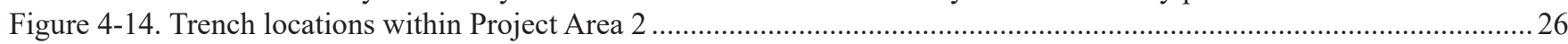

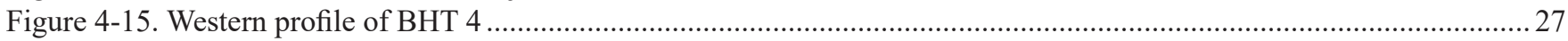

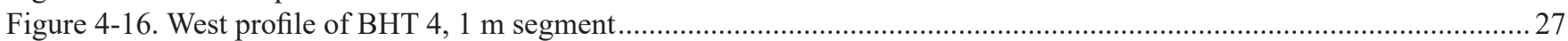

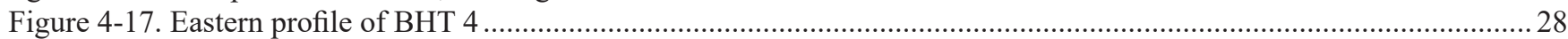

Figure 4-18. Northern profile of BHT 5. Dashed white line demarcates soil change associated with Feature 3 ..................... 29

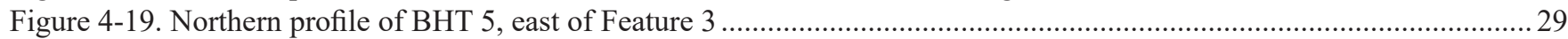

Figure 4-20. Location of trenches and features within Project Area 2. Note that the buildings within the project area

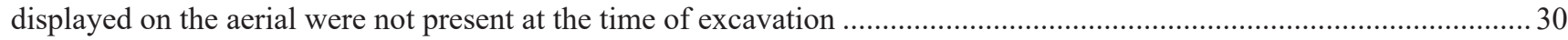

Figure 4-21. Feature 3. Note soil change west of limestone block (facing north). Dashed white line demarcates shift in soil profile

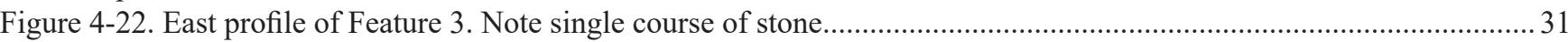

Figure 4-23. Northern profile of BHT 5 showing Feature 3 (outlined in white) ............................................................ 32

Figure 4-24. Feature 4 within BHT 4 (facing east). Dashed white line demarcates feature boundary, and solid white

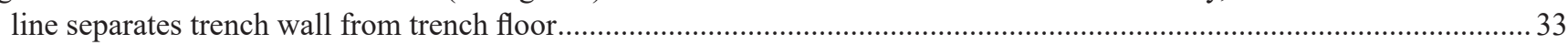

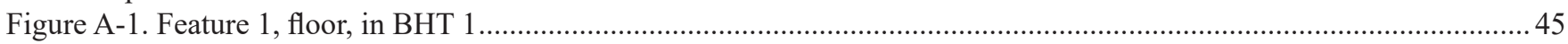

Figure A-2. North profile of BHT 1, Feature 1 to the left and foreground. Solid white line demarcates trench wall from floor.....

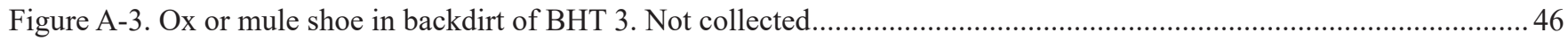

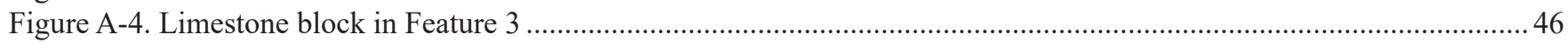

Figure A-5. Brown bottle base (top), stoneware sherd (left) and European Porcelain rim (right) from BHT 4 backdirt. See Table 4-1... 
Figure A-6. Galera body sherd (left) and green glass rim from BHT 5 backdirt. See Table 4-1 ….................................... 47

Figure A-7. Bottle from BHT 4 collected at $105 \mathrm{~cm}$ below the surface. See Table 4-1 .....................................................4 48

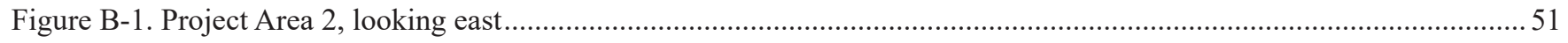

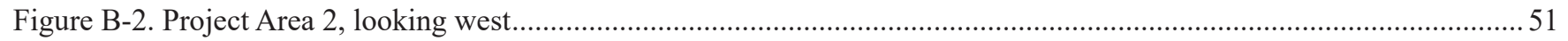




\section{List of Tables:}

Table 2-1. Archaeological Sites within $1 \mathrm{~km}(0.62 \mathrm{mi}$.$) of the Project Areas........................................................................ 11$

Table 4-1. Artifacts Collected from Project Area 2. 
This page intentionally left blank. 


\section{Acknowledgements:}

Thank you to Dr. Raymond Mauldin, CAR Interim Director, for his advice and assistance throughout this project. Thank you to Matthew Elverson, City Archaeologist with COSA-OHP, for his input and assistance on this project, including comments on the draft report. Dr. Emily Dylla and Caitlin Brashear reviewed the draft and provided direction on recommendations. Thanks to Clint McKenzie, who conducted the archival research and assisted with artifact identification. Thank you to Cindy Munoz and Mikaela Razo for their work on the lab and curation processing. Thank you to Dr. Jessica Nowlin and Leonard Kemp for producing the maps used in this report and to Peggy Wall for producing the graphics. Thank you to Dr. Kelly Harris, who edited the final manuscript. Thanks also to Noe Carmona of VIA-MTA for his work facilitating this project. VIA-MTA also provided the backhoe and operator. 
This page intentionally left blank. 


\section{Chapter 1: Introduction}

The work described here was conducted by the Center for Archaeological Research (CAR) at The University of Texas at San Antonio in response to a request from VIA Metropolitan Transit Authority (VIA-MTA). VIA-MTA, a political subdivision of the State of Texas, is proposing to construct new employee parking lots in two project areas in central San Antonio, Texas. Excavation for the placement of these new concrete pavement lots will reach a depth of 25.4 $\mathrm{cm}$ (10 in.). Project Area 1 is located at 209 E. Fredericksburg Road while Project Area 2 is at 712 W. Laurel Street. The two areas are located roughly $10 \mathrm{~m}(33 \mathrm{ft}$.) apart (Figures 1-1 and 1-2). No federal funds are involved in the project.

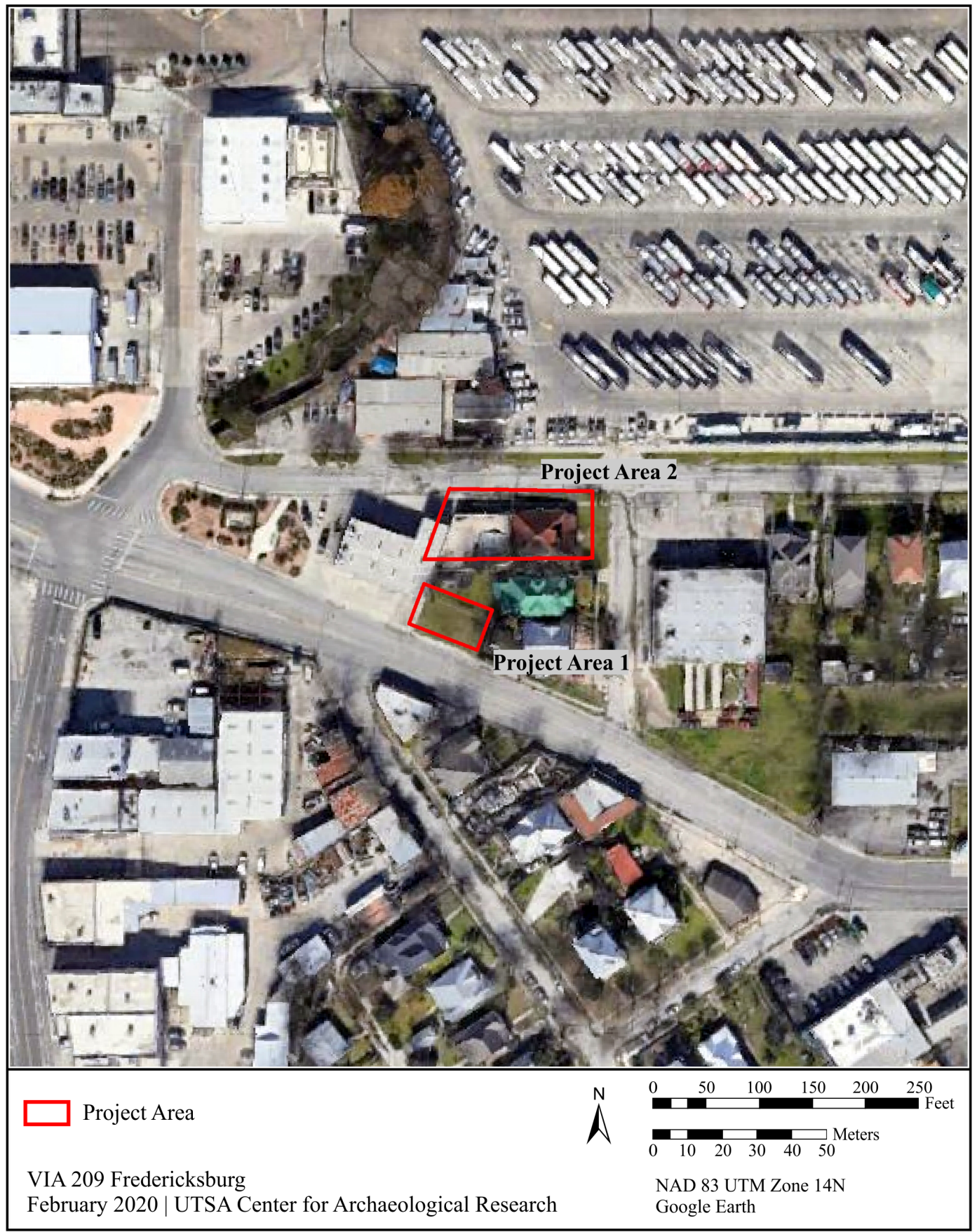

Figure 1-1. Project Areas 1 and 2 on aerial imagery. 


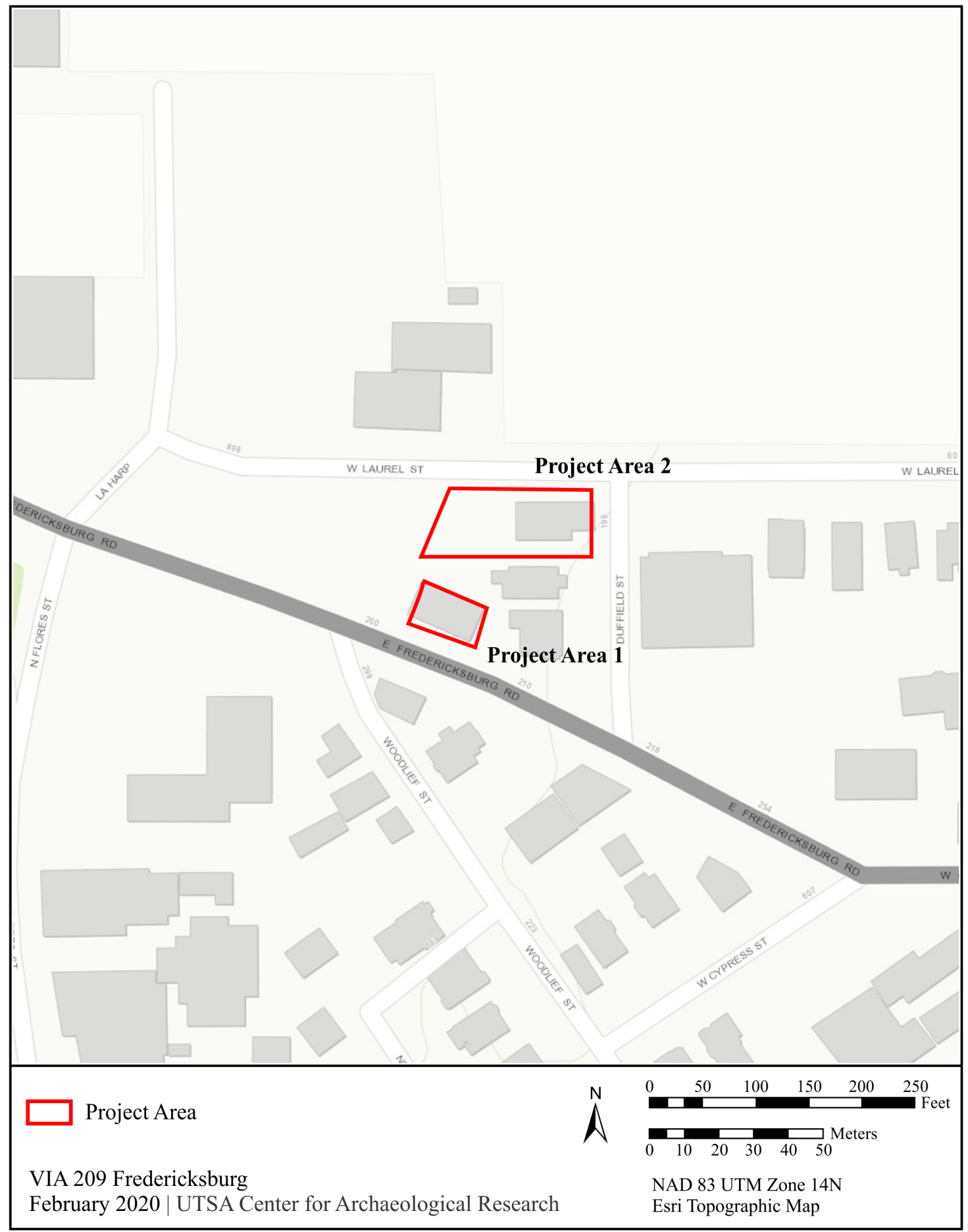

Figure 1-2. Project Areas 1 and 2 on a topographic map.

The project falls under the Texas Antiquities Code, and as such, CAR obtained Texas Antiquities Permit No. 9229, with Dr. Raymond Mauldin, CAR Interim Director, serving as the Principal Investigator and Sarah Wigley serving as the Project Archaeologist. The project also falls under the Unified Development Code of the City of San Antonio (COSA). CAR therefore coordinated planning, excavation, and review with the COSA Office of Historic Preservation (COSA-OHP).
COSA-OHP recommended an archaeological investigation within the two areas due to the potential presence of two Spanish Colonial acequias, the San Pedro Acequia (41BX337) and the Upper Labor Acequia (41BX1273), in the general area. CAR's review of Sanborn Fire Insurance Maps from 1904 and 1911 showed these two acequias intersecting near the Fredericksburg Road area, Project Area 1, in slightly different locations (Figures 1-3 and 1-4). A further review 


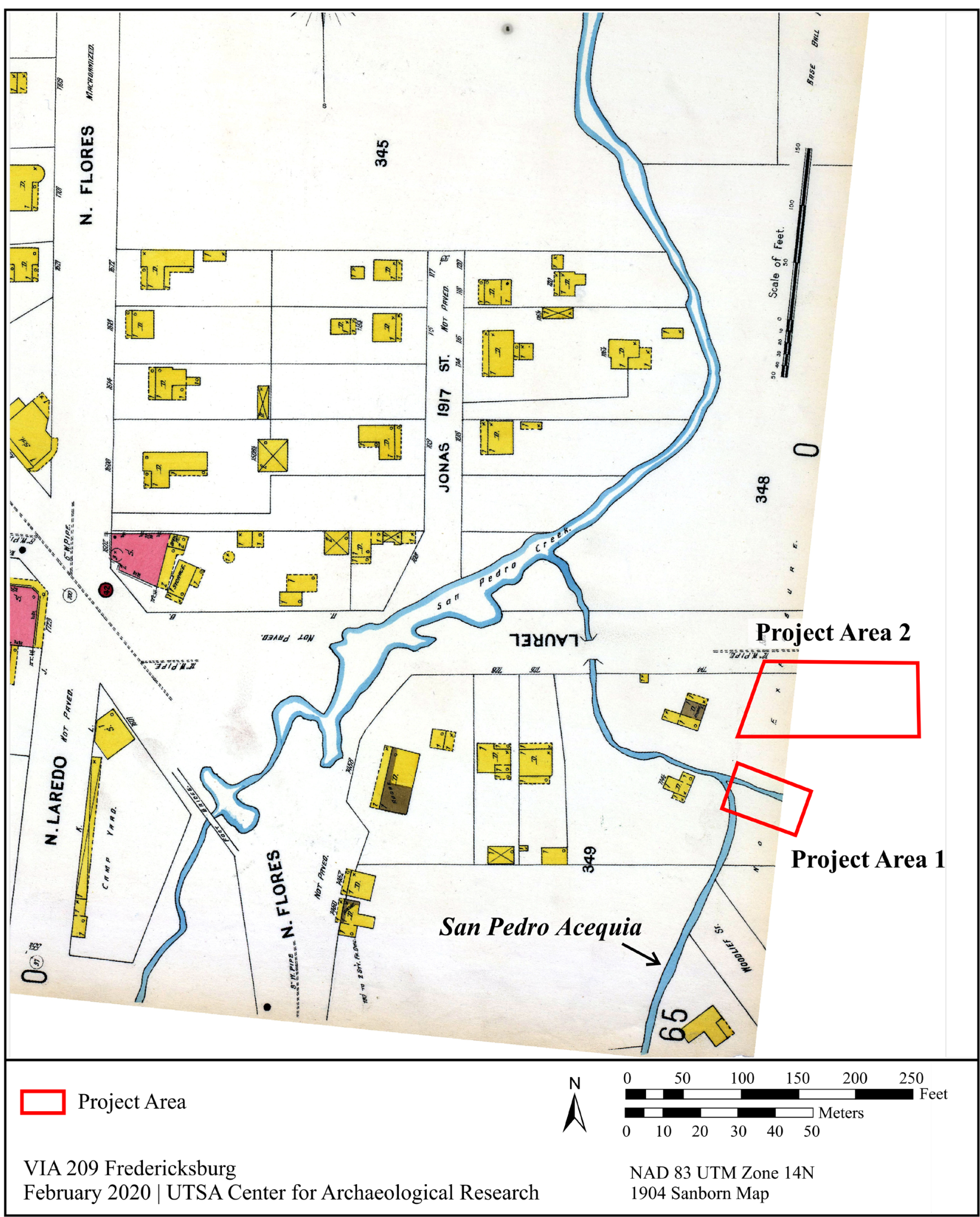

Figure 1-3. Project Areas 1 and 2 on the 1904 Sanborn Fire Insurance Map (Sanborn 1904). Note that the map terminates in the western portion of each project area. 


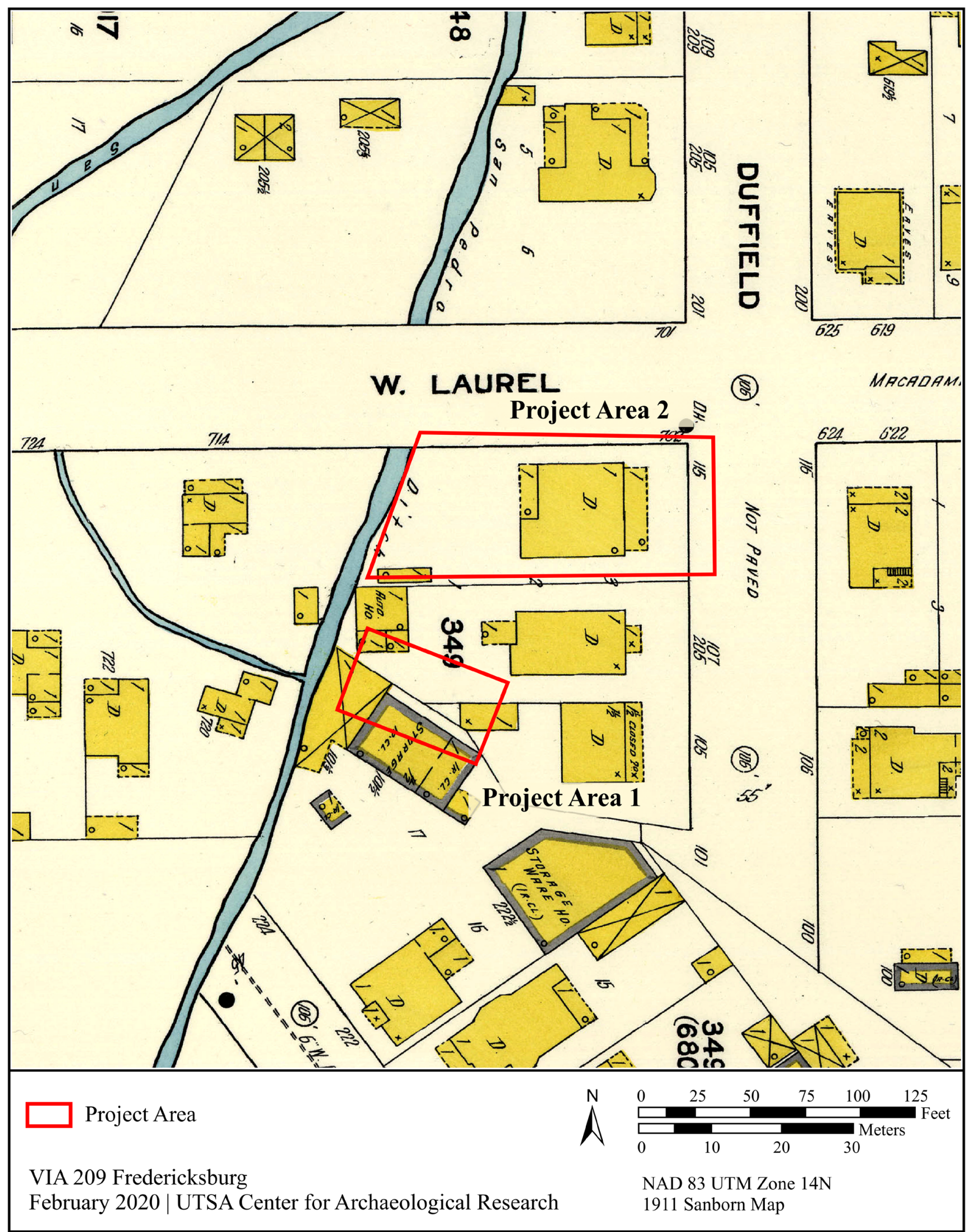

Figure 1-4. Project Areas 1 and 2 on the 1911 Sanborn Fire Insurance Map (Sanborn 1911). 
of the 1911 Sanborn map depicting the Laurel Street area, Project Area 2, showed that the San Pedro Acequia was potentially present, running along the western property boundary (Figure 1-4). Additionally, a review of the Texas Archaeological Sites Atlas showed other archaeological sites recorded within the vicinity.

CAR conducted work on Project Area 1 on January 21 and work on Project Area 2 on February 19, 2020. In Project Area 1, which covered 0.024 ha ( 0.06 ac.), CAR excavated three backhoe trenches. Two trenches were excavated in Project Area 2, a parcel that was roughly $0.089 \mathrm{ha}(0.22 \mathrm{ac}$.) in size.

During the investigation of Project Area 1, CAR documented Feature 1, a segment of the Upper Labor Acequia (41BX1273). This feature was stone lined. Site 41BX1273 is a designated National Historic Civil Engineering Landmark. The San Pedro Acequia (41BX337) was not encountered within Project Area 1. A construction dump, probably modern, was also recorded and designated Feature 2. No artifacts were collected during the investigation of this area.

During the investigation of Project Area 2, Feature 3, a segment of the San Pedro Acequia (41BX337), was documented. This feature was unlined with the exception of a single cut limestone block, possibly a later modification to the channel. The San Pedro Acequia (41BX337) is a designated National Historic Civil Engineering Landmark, and it has been found eligible for designation as a SAL and for inclusion to the NRHP. Within the acequia channel, Feature 4 was recorded. This feature was a discrete white clay deposit, possibly reflecting some sort of dumping event. Several diagnostic artifacts, including glass and ceramic sherds, were collected during the investigation of Project Area 2. These artifacts and all records of the project are curated at CAR under accession 2259.

Impacts to sites 41BX337 and 41BX1273 should be avoided. However, neither of these sites will be impacted by the proposed parking lot construction which has a maximum depth of impact of $25.4 \mathrm{~cm}$ (10 in.). As such, CAR recommends that the construction of the parking areas be allowed to proceed but with a monitor present. The THC and COSAOHP concurred with these recommendations. However, prior to the issuance of those concurrences, VIA-MTA paved Project Area 2 (712 W. Laurel Street) without notifying CAR. No monitor was present for the excavation and paving. CAR subsequently photographed the area. In addition, VIA-MTA no longer plans to do any work in Project Area 1.

\section{Report Outline}

This report includes five chapters. Following this introduction, the second chapter provides a brief environmental and culture history background of the project area, followed by a review of the previous archaeology conducted within $1 \mathrm{~km}(0.62$ mi.) of the project area. The third chapter discusses the lab and field methods employed by CAR during the completion of this project. The fourth chapter provides a discussion of the results of the investigation, and the fifth chapter provides a summary as well as CAR's recommendations. The report is supported by Appendix A that provides supplemental photographic documentation of artifacts, and Appendix B that documents the parking lot at $712 \mathrm{~W}$. Laurel Street. 
This page intentionally left blank. 


\section{Chapter 2: Project Background}

This chapter provides a discussion of the natural environment and culture history of the project area. The chapter concludes with a brief discussion of previous archaeology in the area.

\section{Environment}

Project Areas 1 and 2 are located within central San Antonio in Bexar County, Texas, in a neighborhood known as the Five Points, so named due to the unique intersection of Fredericksburg Road, N. Flores Street, N. Laredo Street, La Harpe Street, and Laurel Street in the vicinity (COSA 2009). The project areas are approximately $134 \mathrm{~m} \mathrm{(440} \mathrm{ft.)} \mathrm{east} \mathrm{of}$ San Pedro Creek. The creek originates just north of the areas in San Pedro Park and flows southeast for $3.2 \mathrm{~km}$ (2 mi.) to the San Antonio River (Texas State Historical Association [TSHA] 2010). Project Area 1 is bounded by Fredericksburg Road to the south, VIA-MTA property to the west, and private property to the north and east. Project Area 2 is bounded by private property to the south, Laurel Street to the north, Duffield Street to the east, and VIA-MTA property to the west. The surrounding area is urban, with a mix of residential and commercial development.

The soils within the project area are classified as Branyon Clays. These soils have one to three percent slopes, are moderately well drained, and reach depths of more than $2 \mathrm{~m}$ (6.6 ft.). They are found on stream terraces and are described as prime farmland (National Resources Conservation Service [NRCS] 2020). The project areas are located within the Southern Backland Prairie ecoregion. Natural vegetation in this ecoregion includes tallgrass species such as big bluestem (Andropogon gerardii), Indiangrass (Sorghastrum nutans), switchgrass (Panicum virgatum), eastern gramagrass (Tripsacum dactyloides), little bluestem (Schizachyrium scoparium), abundant midgrasses, a wide variety of forbs, western hackberry (Celtis occidentalis), live oak (Quercus virginiana) and elm (Ulmus sp.). As is the case in the area, most of the natural vegetation in this ecoregion has been lost, first due to agricultural activities, then to urban development. Less than one percent of the native prairie environment remains within the Blackland Prairie ecoregion (NRCS 2020).

San Antonio is positioned where the southernmost Great Plains meets the Gulf Coast, demarcated by the Balcones Escarpment. It is also near a significant climate boundary, partitioning a humid-subtropical from an arid zone (Petersen 2001). The city's location near these significant geological and climactic boundaries results in a varied resource base. The area contains a number of reliable freshwater sources, including the San Antonio River, freshwater artesian springs, and the Edwards Aquifer. The growing season averages 270 days (Petersen 2001:22). The temperature reaches average lows of $39.2^{\circ} \mathrm{F}\left(4^{\circ} \mathrm{C}\right)$ in January and average highs of $96.8^{\circ} \mathrm{F}$ $\left(36^{\circ} \mathrm{C}\right)$ in July (Long 2017$)$. Though highly variable, the average annual rainfall is approximately $76.2 \mathrm{~cm}$ (30 in.), with seasonal peaks in the spring and fall (Petersen 2001:22). The project area is located near the borders of the Balconian biotic province, which is described as an intermediate ecological area between the eastern forest and the western desert, and the Tamaulipan biotic province, which has semiarid climate and is dominated by thorny brush (Blair 1950).

\section{Culture History}

Though San Antonio's culture history includes a significant prehistoric component (see Collins 2004 for a review of the prehistoric culture history of the region), this background will focus on the Historic period as no prehistoric sites were documented during the course of this project. In Central Texas, the Historic period began with the first documented appearance of Europeans in AD 1528. Although early interactions between Europeans and indigenous populations in the area were infrequent, the lifeways of the indigenous populations were still impacted by loss of population due to disease and the arrival of Native American groups from other regions of North America fleeing European incursions (Foster 1998; Kenmotsu and Arnn 2012).

In 1519, following the Alonso Álvarez de Pineda voyage, Spain laid claim to the area that would become Texas but made little attempt to establish settlement (Chipman and Joseph 2010). Motivated by concerns about French colonization in Louisiana in the early 1700s and encroachment into Texas in 1685 by Robert Cavalier, Sieur de la Salle's expedition led the Spanish government to strengthen its hold on Texas, which previously was sparsely populated by Europeans (Cruz 1988). A Spanish expedition intended to initiate contact with the indigenous population and prevent them from establishing trade relationships with the French reached the San Pedro Springs, just north of the project area, in present-day San Antonio on April 13, 1709 (Cruz 1988).

The primary institutions Spain employed to secure its colonies were the missions, used to assimilate the indigenous population through religious conversion, the presidio, which played a military defensive role, and, ultimately, the establishment of chartered town settlements (Cox 1997; de la Teja 1995). The mission and the presidio were intended to be transitory institutions, whose land and possessions would ultimately be distributed among successfully converted indigenous families 
(de la Teja 1995). The Spanish Colonial acequia system in San Antonio was established to serve as a source of water and irrigation for the inhabitants of these mission and presidio. San Antonio is one of the few large cities of Spanish origin that still contains traces of its original acequia system, spanning more than $80 \mathrm{~km}$ (50 mi.; Cox 2005).

Mission San Antonio de Valero, the first Spanish settlement established in what would become San Antonio, was founded on May 1, 1718, on the west bank of the San Antonio River south of San Pedro Springs (Habig 1968: 38). The Presidio de Bexar and the Villa de Bexar were established four days later. Initially, these settlements were located near the San Pedro Springs, possibly within modern-day San Pedro Park (Meissner 2000), although firm archaeological evidence of these early settlements has not been documented. The mission was moved to the east bank of the San Antonio River about a year later, and it was moved a third time to its final location following storm damage in 1724 (Habig 1968:44). The villa and presidio were relocated in 1722 (Habig 1968:38). Archaeological material associated with this second location of the presidio, including a Spanish Colonial sheet midden, have been documented at site 41BX2088 (McKenzie et al. 2016). Four more missions were founded to the south along the San Antonio River between 1720 and 1731 (de la Teja 1995).

Although an early, unofficial town settlement associated with the presidio began to develop with the arrival of presidio soldiers and their families, this settlement lacked legal status (de la Teja 1991). The arrival of a group of immigrants from the Canary Islands in 1731 marked the establishment of the Villa de San Fernando (Buck 1980; de la Teja 1995; Poyo 1991). The villa was granted water rights to the San Pedro Creek (de la Teja 1995). The early years of the settlement were marked with conflict between the villa, the missions, and the earlier settlers, particularly over land and irrigation (Buck 1980; de la Teja 1991, 1995; Poyo 1991). An acequia for the new settlement, the San Pedro, was in operation by 1735 (Cox 2005:35). The San Pedro Acequia was approximately $6.4 \mathrm{~km}$ (4 mi.) in length, and it watered $161 \mathrm{ha} \mathrm{(400} \mathrm{ac.)}$ south of the villa (Cox 2005). It ran south from San Pedro Springs between San Pedro Creek and the San Antonio River (Cox 2005), following a projected path that cuts through both Project Areas 1 and 2.

The Upper Labor Acequia was completed in 1778, intended to irrigate approximately $242.8 \mathrm{ha}(600 \mathrm{ac}$.) of land that had previously functioned as commons for grazing. These lands, located west of the river and north of the presidio, were known as the Labors de Arriba, or the Upper Farms (McKenzie 2017). They were opened in order to accommodate the growth of the town, and those wishing to receive grants were required to contribute to the construction of the acequia (de la Teja
1995). At southern end, the Upper Labor Acequia crossed the San Pedro Acequia using a wooden canoa, or hollow log, to return to the San Pedro Creek (Cox 2005; McKenzie 2017). This may later have been replaced by a stone aqueduct (Cox 2005). Archival maps suggest that this intersection occurred near Project Area 1 (Figures 2-1 and 2-2; see also Figures 1-3 and 1-4), although all four of these maps differ slightly in their depictions. Cox suggests that this section of the Upper Labor Acequia may have repurposed an older acequia alignment (Cox 2005).

In 1793, the Mission Valero was secularized, and the lower farms were surveyed and distributed (Cox 1997; de la Teja 1995). The mission compound subsequently served primarily a military function in the city, and it was, significantly, the site of the Battle of the Alamo in 1836. The other missions were not fully secularized until 1824, when their churches and furnishings were inventoried and surrendered (Habig 1968). However, they were partially secularized in 1794 , when their farmlands were surveyed and redistributed, and the distribution of former mission farmlands contributed to the growth of the town (de la Teja 1995).

A failed uprising for independence from Spain in 1812 depleted San Antonio's population and negatively affected the city's development for decades (Cox 1997). Mexico gained independence from Spain in 1821, and Texas became part of the state of Coahuila. Texas revolted against Mexico in 1835. Mexican General Martín Perfecto de Cos fortified the old Mission Valero against the Texans, including diverting a branch of the acequia to flow outside the Mission compound (Cox 1997). The Texans defeated General Cos, but they were defeated themselves by Santa Anna after 13-day siege in 1836 at what became known as the Battle of the Alamo (Cox 1997). A number of sites downtown include features associated with this military activity, including a trench feature associated with General Cos' occupation of Main Plaza at 41BX1752 (Hanson 2016), and a Mexican fortification trench associated with the Siege of Bexar at 41BX2170 (Kemp et al. 2019). However, in the fall of 1836, Santa Anna was ultimately defeated, and Texas became a Republic (Cox 1997).

In the century that followed Texas's break with Mexico, the city saw considerable growth despite the impact of numerous conflicts. In December of 1837, San Antonio was incorporated as one of the early acts of the newly established Republic of Texas. A number of epidemics impacted the city's population during the early to mid-1800s, spread in part by pollution of the city's acequia system. The City attempted to combat the issue by establishing standards of cleanliness, but the issue remained ongoing (Cox 2005). After a turbulent period in which Texas saw conflict with both Mexico, which rejected the new Republic's independence, and local Native American groups, Texas became part of the United States in 1846. 


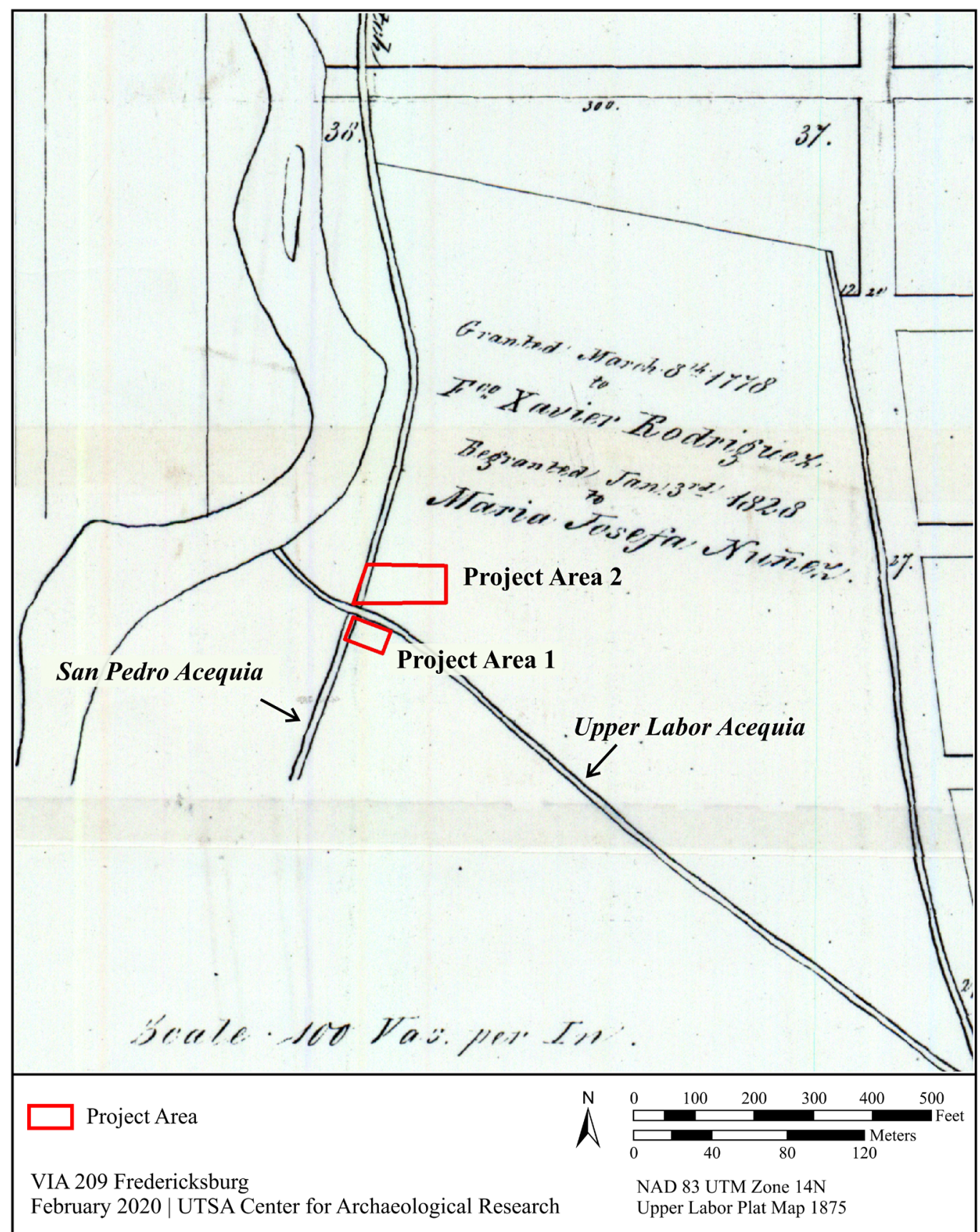

Figure 2-1. Project Areas 1 and 2 overlain on the Freisleben 1875 map (Freisleben 1875). Note the intersection of the San Pedro (north-south) and the Upper Labor (east-west) acequias.

In the 1840 s, a number of French and German immigrants began to settle in San Antonio and the surrounding area. The Five Points neighborhood in particular included a number of German businesses during the 1800s (Uecker 1991). Cultural material associated with one such business in the area, Wohlfarth's mercantile, was recorded by the CAR in 2014 (McKenzie 2015). By the 1850s, recent European settlers outnumbered the Mexican and Anglo populations in the city (Cox 1997). Texas seceded from the United States, joined the Confederacy in 1861, and primarily served a supply role during the Civil War. Five years later, Texas surrendered to the Union and rejoined the United States (Wooster 2018).

The arrival of the railroad in 1877 resulted in significant growth in San Antonio (Cox 1997). The Five Points neighborhood began to be subdivided for residences in the late 1800s (Uecker 1991). The late 1800s saw infrastructure and economic development throughout the city, including water, electric, and gas utilities (Heusinger 1951). The City also attempted to update the acequia system with the construction 


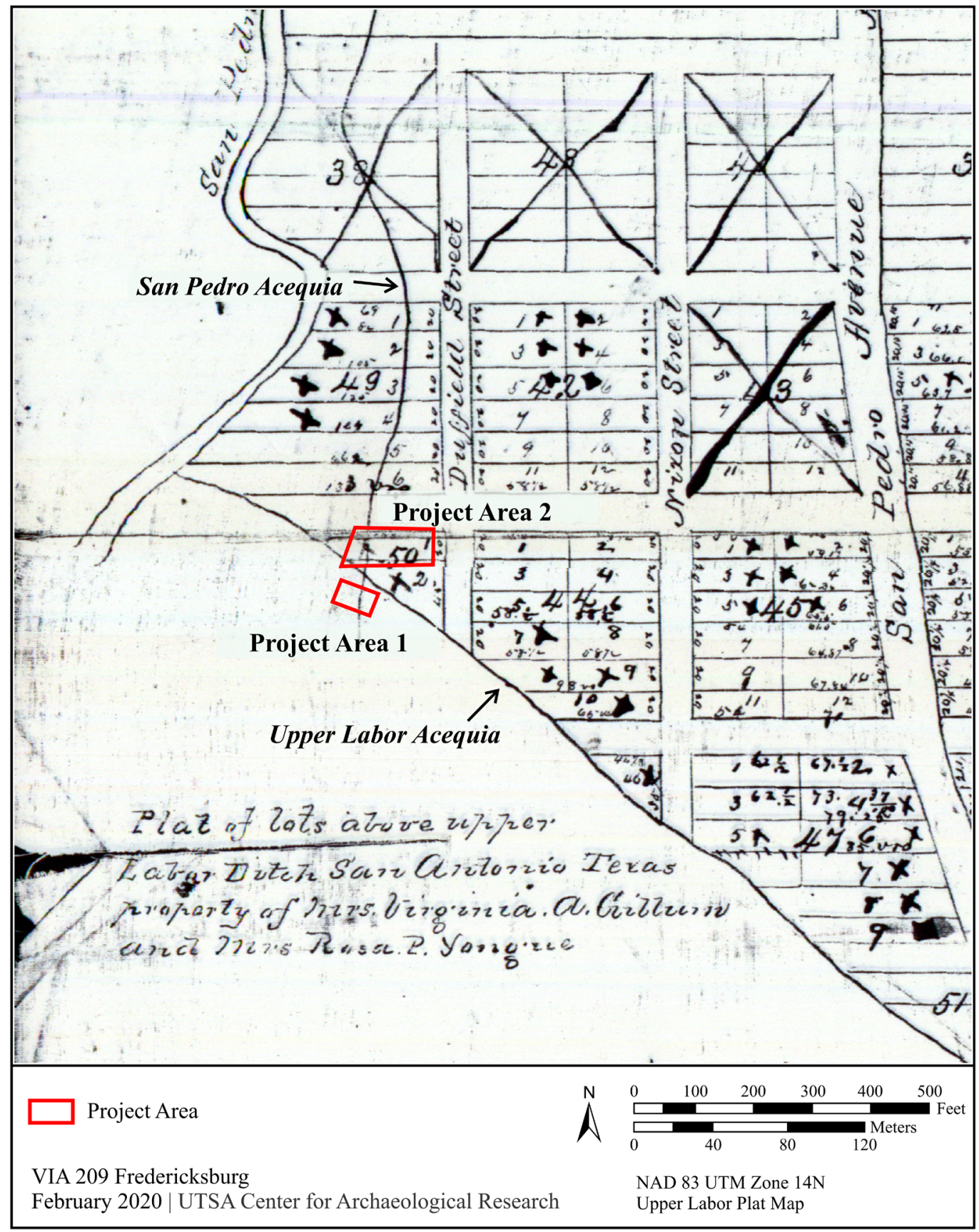

Figure 2-2. Project Areas 1 and 2 overlain on an 1877 plat map (Bexar County Deed Records V6:565). Note the intersection of the San Pedro and Upper Labor acequias.

of new ditches, including the construction of the Alazán Acequia in 1875. Construction of this new ditch necessitated modifications to the Upper Labor Acequia as well (McKenzie 2017). The adoption of the new water works system in 1878 transformed the acequia system into, primarily, a drainage system, and water flow was reduced in the 1890s due to the increased drilling of wells. As a result of these infrastructural changes in the city, as well as ongoing cleanliness issues, the Upper Labor Acequia was closed in 1896, and the San Pedro Acequia was closed in 1912 (Cox 2005).

\section{Previous Archaeology}

A search of the Texas Archaeological Sites Atlas identified four archaeological sites within $1 \mathrm{~km}(0.62 \mathrm{mi}$.) of the project areas (Table 2-1 and Figure 2-3). A review of archival sources indicated the potential to encounter the intersection of two acequias, the San Pedro (41BX337) and the Upper Labor (41BX1273), within the project areas (Sanborn 1904, 1911; see Figures 1-3, 1-4, 2-1, and 2-2). Each of the sources illustrated the alignment and intersection of the two acequias 
Table 2-1. Archaeological Sites within $1 \mathrm{~km}$ (0.62 mi.) of the Project Areas

\begin{tabular}{|c|c|c|c|}
\hline Site & Name & Time Period & Site Type \\
\hline 41BX19 & San Pedro Springs & Prehistoric/Spanish Colonial & Occupation \\
\hline 41BX514 & $\begin{array}{c}\text { Chapel of Miracles/ } \\
\text { Ximenes Chapel }\end{array}$ & Spanish Colonial/Historic & Church \\
\hline 41BX620 & Alazán Acequia & Historic & Acequia \\
\hline 41BX2043* & Upper Labor Acequia & Spanish Colonial/Historic & Acequia \\
\hline
\end{tabular}

*discussed in Archaeological Background of the Upper Labor Acequia (41BX1273)

Redacted Image

Figure 2-3. Previous archaeology, including the location of acequias. 
in slightly different locations, but all showed both of the acequias within or close to the project areas. In addition to the sites recorded within $1 \mathrm{~km}(0.62 \mathrm{mi}$.), multiple archaeological surveys that have no recorded archaeological sites have taken place within the $1 \mathrm{~km}(0.62 \mathrm{mi}$.) of the project areas.

\section{Sites and Projects within $1 \mathrm{~km}(0.62 \mathrm{mi}$.) of the Project Areas}

Site 41BX19 includes the San Pedro Springs and surrounding area in modern-day San Pedro Park. The site contains prehistoric and historic materials, and it is a NRHP site as well as a SAL. The site has an extensive history of avocational exploration dating back to the 1870s, which includes reports of human remains (Mauldin et al. 2015). The site was formally recorded by the Witte Museum in 1966 as a prehistoric site and the location of earliest Spanish settlement in San Antonio (Mauldin et al. 2015; THC 2020). Portions of the Alazán Acequia have been documented within the park boundaries (Fox 1978; Meissner 2000). Multiple investigations have attempted to locate intact portions of the San Pedro Acequia and dam within the park, but none have been successful (Houk 1999; Mauldin et al. 2015). Intact historic deposits have been documented (Zapata and Meissner 2003) as well as intact prehistoric deposits dating to the Late Archaic and Late Prehistoric (Mauldin et al. 2015), despite evidence of extensive disturbance in many areas of the park as a result of construction (Mauldin et al. 2015).

The Texas Archaeological Sites Atlas record includes no data on site 41BX514 outside of its location, but CAR's 1979 review of cultural resources in the area describes this site as the "Chapel of Miracles" (Fox 1979:11). The site is listed on the NRHP (National Park Service [NPS] 1980), where it is named "Ximenes Chapel." Ramsdell (1976) describes the site as the shrine of a large crucifix potentially rescued from the San Fernando Cathedral following a fire in 1813. The NRHP lists the chapel's "periods of significance" as 1850-1874 (NPS 1980). No other records could be located for 41BX514.

Site 41BX620 is the Alazán Acequia. This site was first recorded by Fox in 1978, but a trinomial was not assigned until 1983 (Fox 1978; THC 2020). Construction of this late addition to the acequia system was completed in 1875 , and it includes portions encased in limestone that run below ground (Nickels and Cox 1996). The Alazán Acequia functioned poorly from the beginning of its construction, and it was closed by 1903 (Thomas and McKenzie 2019). Portions of the Alazán Acequia have been documented during a number of archaeological projects (Fox 1978; Labadie 1987; Nickels and Cox 1996; THC 2020; Thomas and McKenzie 2019).
In 1979, CAR conducted a review of cultural resources surrounding the San Antonio River and San Pedro Creek for the United States Army Corps of Engineers (Fox 1979). These resources included archaeological, historical, and architectural resources documented at that time. One resource included in this review near the project area that is not included on the Texas Archaeological Sites Atlas is the Frank Walsh house, built around 1860, which Fox noted was in imminent danger of being bulldozed for highway construction at the time of writing (Fox 1979).

In 2014, CAR conducted an archaeological investigation for VIA about $115 \mathrm{~m}$ (377 ft.) west of the current project areas. The primary concern during the course of the 2014 project was the potential for prehistoric deposits and the potential presence of a private acequia, the Arocha Acequia, within the project area. No archaeological sites were documented during the course of this work, although evidence of the locations use as a historic wagon yard (Wohlforth's) that included historic artifacts and features associated with an 1885 building, were noted (McKenzie 2015).

In 2016-2017, CAR conducted archaeological monitoring and backhoe trenching about $55 \mathrm{~m}(180 \mathrm{ft}$.) northwest of the current project area, across Laurel Street from Project Area 2. The project encountered a small amount of prehistoric and historic material, all in disturbed contexts, and found

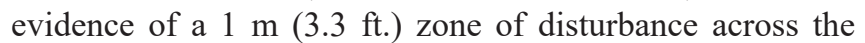
project area (Zapata and McKenzie 2017).

In 1989, CAR conducted an archival review of the area adjacent to San Pedro Creek to the immediate west of the current project area for the San Antonio River Authority (Uecker 1991). This review documented the agricultural use of the area during the Spanish Colonial period and residential development during the mid-to-late 1800s. After the arrival of the railroad in San Antonio, the area's central location to a variety of commercial traffic led to commercial development of the area, including the transportation and processing of cattle. The area was regarded as potentially containing significant prehistoric, colonial, and historic deposits, including the Spanish Colonial acequias (Uecker 1991).

\section{Archaeological Background of San Pedro Acequia (41BX337)}

A section of the San Pedro Acequia was documented in 1977 by CAR on the grounds of the Commander's House on Flores Street in central San Antonio. The acequia was initially exposed in a plumbing trench. It had been capped with a thin layer of cement. The acequia was stone lined, measuring $150 \mathrm{~cm}$ (4.9 ft.) in width with walls approximately $50-60 \mathrm{~cm}$ (1.64-1.97 ft.) wide and a channel $105 \mathrm{~cm}$ (3.4 ft.) deep. A 
small gate opening into a stone-lined lateral ditch was also documented. The only artifacts recovered from the acequia were brick fragments and a mule shoe (Fox 1978).

The site trinomial (41BX337) was recorded by CAR in 1979 (Valdez and Eaton 1979). A portion of the acequia was encountered during backhoe trenching by CAR in 1979 south of the U.S. Arsenal. The two northernmost sections identified were unlined, while two stone-lined sections of a bend in the acequia were recorded near Flores and Johnson streets. All identified sections were 1-20 m (3.3-66 ft.) north and west of the projected alignment based on archival review (Valdez and Eaton 1979). Further investigation of the area (Frkuska 1981) revealed the acequia had been re-routed at one point, and both unlined and stone-lined sections were present. Ceramic, glass, and metal artifacts were recovered.

Nearer to the current project area, CAR documented sections of the San Pedro Acequia to the north across Laurel Street (Cox 1986, 1993; Figure 2-4). These sections are not recorded in the Texas Archaeological Sites Atlas. In 1985, a portion of the San Pedro Acequia (41BX337) was documented approximately $50 \mathrm{~m}(164 \mathrm{ft}$.) to the north of the current project area below the current VIA parking lot. The northernmost portion was found to be unlined, while the portion closest to the project area was lined with limestone blocks. The

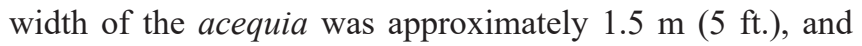
the width of walls was about $45.7 \mathrm{~cm}$ (18 in.). An associated cedar post was documented. The feature was identified just below the surface. The excavation did not extend to the acequia interior, and all documented artifacts dated to the twentieth century. A trench in the center of the project area indicated significant disturbance, suggesting the feature did not continue uninterrupted through the project area. This portion was found to be eligible for the NRHP (Cox 1986). In 1986, another unlined section of the acequia was documented about $33.5 \mathrm{~m}$ (110 ft.) south of Myrtle Street, below proposed bus parking facilities. This section was found $33 \mathrm{~cm}$ (13 in.) below the surface, and it was about $2 \mathrm{~m}(6.6 \mathrm{ft}$.) wide and $1.07 \mathrm{~m}$ (3.5 ft.) deep (Cox 1993). Lined and unlined portions of the San Pedro Acequia (41BX337) have continued to be encountered during the course of construction projects in San Antonio, including by the CAR in 1994 (Cox 1995) and by SWCA in 2019 (THC 2020).

\section{Archaeological Background of the Upper Labor Acequia (41BX1273)}

In 1987, a small, unlined section of the Upper Labor Acequia was recorded in a construction trench near the intersection of E. Myrtle Street and N. St. Mary's Street by CAR. It was observed to have been used previously as a ready-made trench for an iron pipe. The acequia was recommended at this time as eligible for the NRHP (Fox and Cox 1988).

A portion of the Upper Labor Dam was documented following partial exposure during a rainstorm in Brackenridge Park in 1996 (Cox et al. 1999). It was at this time the dam and acequia were assigned trinomial 41BX1273 (Cox et al. 1999; THC 2020). Backhoe trenching by CAR revealed portions of a limestone dam showing evidence of two different periods of construction. The lower portion of the dam, apparently Spanish Colonial, consisted of roughly cut limestone blocks with associated cedar posts. Above this component were cut, ashlar-dressed limestone blocks attributed to later nineteenth century modifications. The two components followed a slightly different alignment. The site was recommended as eligible for the NRHP and as a SAL (Cox et al. 1999).

The dam was revisited by the CAR in 2013-2014 (McKenzie 2017). At this time, the dam and the acequia were recorded as a new trinomial, 41BX2043, by CAR (THC 2020); however, this trinomial is not used in the associated report, which instead uses the designation 41BX1273 for both the dam and acequia (McKenzie 2017). Discussion of trinomial 41BX2043 is included here because it was subsequently updated twice (THC 2020), but the first trinomial (41BX1273) will be used in this report. The 2013-2014 investigation concluded that the dam functioned as a weir dam and that the later construction period dates to the Confederate era. The description of the nature of its construction aligns with the previous investigation, including the use of two different types of limestone and the presence of cedar posts (Cox et al. 1999; McKenzie 2017). Multiple impacts to the dam across its length were also identified during the investigation (McKenzie 2017).

Multiple sections of the Upper Labor Acequia (41BX1273) have been documented. Within Brackenridge Park, the acequia was documented by Abasolo Consultants in 2010 and 2012 (McKenzie 2017). One of these was a secondary ditch of the main channel, and both were stone lined, with modifications dating to the Works Progress Administration (WPA) era. An unlined, rubble filled channel was documented about $365 \mathrm{~m}(1,200 \mathrm{ft}$.) southeast of the project area by SWCA in 2014. This unlined section was recommended as ineligible for the NRHP and as a SAL due to disturbance (THC 2020).

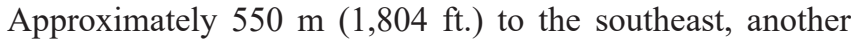
unlined channel containing late nineteenth- to the early twentieth-century material was documented by South Texas Archaeological Research Services (THC 2020). 
Redacted Image

Figure 2-4. Projected location of the acequias as blue lines. The dots identify locations near the project area where sections of the San Pedro Acequia were previously documented by the CAR. Locations are georeferenced based on report maps (Cox 1986:Figure 1, 1993:Figure 1). 


\section{Chapter 3: Methodology}

This chapter details the field and laboratory methods employed during the investigation. The discussion includes analytical definitions, methods of excavation, laboratory processing methodology, and curation standards.

\section{Field Methods}

For the purposes of this investigation, an archaeological site was defined as dating prior to 1950 and containing: (1) five or more surface artifacts within a $15 \mathrm{~m}(49.2 \mathrm{ft}$.) radius (ca. $706 \mathrm{~m}^{2}$ ); or (2) a single cultural feature, such as a hearth, observed on the surface or exposed in backhoe trenching; or (3) a positive backhoe trench containing at least five artifacts.

The scope of work prepared for the THC proposed to excavate two backhoe trenches (BHT) along the eastern and western edges of Project Area 1, and the permit amendment proposed two trenches along the western and northern edges of Project Area 2. BHT 1 extended east-west along the southern edge of the Project Area 1, and BHT 2 extended north-south along the eastern edge. The goal of this configuration was to intersect the potential alignment of both the San Pedro Acequia (41BX337) and the Upper Labor Acequia (41BX1273) determined during the review of the Sanborn maps of the area (Sanborn 1904, 1911; Figure 3-1). A third trench (BHT 3) was excavated perpendicular to BHT 1 in order to explore Feature 1. In Project Area 2, BHT 4 extended north-south along the western edge of the project area, and BHT 5 extended eastwest perpendicular to the northern edge of BHT 4 (Figure 3-1). The goal of this configuration was to intersect the potential alignment of the San Pedro Acequia (41BX337) based on the review of Sanborn maps of the area (Sanborn 1911).

Trenches were on average 3-4 $\mathrm{m}$ (9.8-13.1 ft.) in length, with the exception of BHT 4, which extended along most of the property line of Project Area 2. Backhoe trenches were approximately $1 \mathrm{~m}$ (3.3 ft.) wide and $1.5 \mathrm{~m}$ ( $4.9 \mathrm{ft}$.) deep unless a feature or other obstruction was encountered. Backhoe excavations followed guidance as established by OSHA Trenching and Safety Standards.
A standard form was completed for all trenches. All field forms were completed with pencil. Archaeologists produced measured drawings of a $1 \mathrm{~m}(3.3 \mathrm{ft}$.) representative section of the stratigraphy of each trench, including descriptions of soil type. Trench profiles were photographed. Prior to documentation, the soil stratigraphy and backdirt were examined for evidence of cultural material. Only temporally diagnostic artifacts were collected. All BHT locations were recorded using a Trimble Geo XT GPS unit and were handsketched onto aerial photographs.

When features were encountered, excavation was halted, and the City Archaeologist was notified. Features were documented using a standard form and photographed, supported by handdrawings where appropriate. Their locations were recorded by GPS. The Project Archaeologist maintained a daily log of activities. Activities documented in this log were supported by digital data, including GPS observations and photographs. A photographic log was maintained in addition to the daily log.

\section{Laboratory Methods}

All cultural materials and records obtained and/or generated during the project were prepared in accordance with 36 CFR part 79 and THC requirements for State Held-in-Trust collections. Artifacts processed in the CAR laboratory were washed, air-dried, and stored in 4-mm, zip-locking, archivalquality bags. Materials needing extra support were doublebagged. Acid-free labels were placed in all artifact bags. Each label contained provenience information and a corresponding lot number written in archival ink or pencil or printed with a laser printer. Ceramics were labeled with permanent ink over a clear coat of acrylic and covered by another acrylic coat. Artifacts were separated by class and stored in acid-free boxes. Digital photographs were printed on acid-free paper, labeled with archivally appropriate materials, and placed in archival-quality sleeves. Upon completion of the project, all project-related documentation and collected materials will be permanently curated at the CAR. 
Redacted Image

Figure 3-1. Trench locations on the 1911 Sanborn Fire Insurance Map (Sanborn 1911). 


\section{Chapter 4: Results}

This chapter discusses the results of CAR's work in the two project areas. Three exploratory backhoe trenches were excavated within Project Area 1 on January 21, 2020. Two features, designated Features 1 and 2, were recorded during the course of that trenching. Feature 1 is identified as a section of the Upper Labor Acequia (41BX1273). Feature 2 appears to be the remains of a construction dump. Two additional backhoe trenches were excavated in Project Area 2 on February 19, 2020. Two more features, designated Features 3 and 4, were recorded during the course of that backhoe trenching. Feature 3 is likely a segment of the San Pedro Acequia (41BX337). Feature 4 is a white lime deposit within the San Pedro Acequia (41BX337) channel that may represent some sort of dump.

\section{Project Area 1}

Project Area 1 is located at 209 E. Fredericksburg Road. Figure 4-1 shows the area as it appeared in January of 2020. Three backhoe trenches were excavated within Project Area 1. BHTs 1 and 2 attempt to intersect the potential north-south alignment of the San Pedro Acequia (41BX337) and the potential east-west alignment of the Upper Labor Acequia (41BX1273) that were depicted intersecting on Sanborn maps $(1904,1911)$. BHT 3 was excavated to further explore a section of the Upper Labor Acequia (41BX1273) that was identified in BHT 1. Figure 4-2 shows the locations of these trenches within Project Area 1.

BHT 1 was excavated at the southwest corner of Project Area 1 , aligned roughly east-west just north of the sidewalk. The trench could not be excavated to the edge of the property line as a marked gas line was present along the western edge of the area (Figure 4-3). The trench extended $3.05 \mathrm{~m}$ (10 ft.). This trench was located to intersect the north-south alignment of the San Pedro Acequia (41BX337), depicted on Sanborn maps $(1904,1911)$ as near the western edge of the property (see Figures 1-3, 1-4, and 3-1). A limestone cobble floor, designated Feature 1, was found at $75 \mathrm{~cm}$ below the surface (29.5 in.; Figure 4-4). The feature extended the length and width of BHT 1. To avoid damaging the feature, the trench was terminated at this depth. Layer 1, which was the top 20$35 \mathrm{~cm}$ (7.9-13.8 in.) of the north soil profile, consisted of a loose, disturbed layer of very dark grayish brown (10YR 3/2)

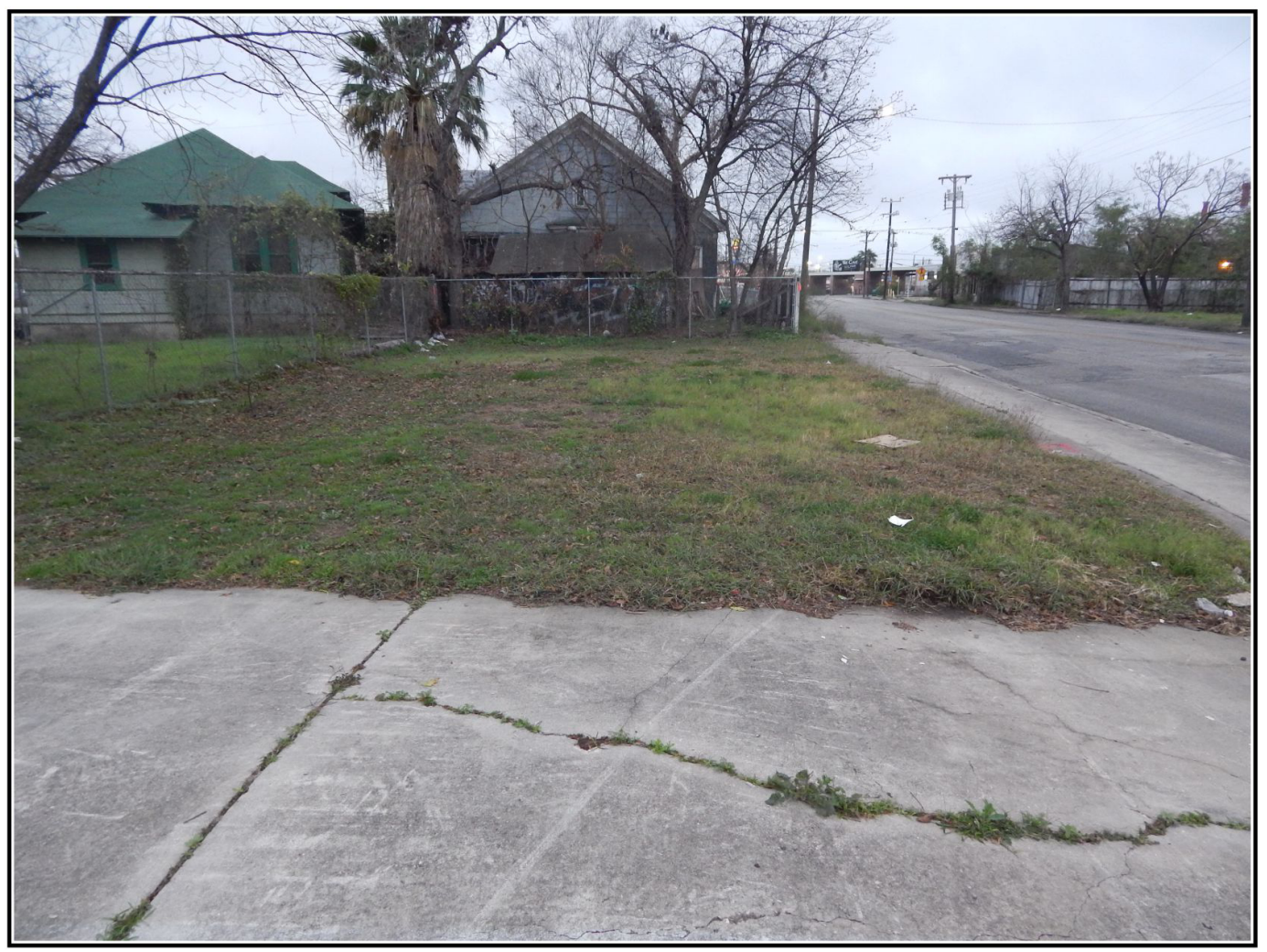

Figure 4-1. Project Area 1, prior to excavation. Facing east. Area is defined by the chain-link fence on the north and east, the sidewalk on the south, and the driveway (foreground) on the west. 
Redacted Image

Figure 4-2. Project Area 1 showing trench locations.

silty clay containing gravels and, in the south profile, cobbles (Figure 4-5). Below this layer, the south profile contained evidence of multiple fill episodes with distinct layers of sand and gravel (see Figure 4-4). Layer 2 of the north profile contained a blocky black (10YR 2/1) clay with carbonates and limestone cobbles from $35-75 \mathrm{~cm}$ (13.8-29.5 in.). A 1-2 $\mathrm{cm}(0.39-0.79 \mathrm{in}$.) wide intrusion of very pale brown (10YR $8 / 4$ ) sand was noted in the north profile from $40-75 \mathrm{~cm}$ (15.75-29.5 in) below the surface. No artifacts were observed in either the backdirt or the profiles. The feature is discussed in the subsequent section.
BHT 2 was excavated at the northeast corner of Project Area 1 (see Figure 4-2). It was aligned north-south and located just south of the fence line. The initial goal of this trench was to attempt to intersect the east-west alignment of the Upper Labor Acequia (41BX1273) that was projected on the 1904 Sanborn map to be present across the northern half of the property (see Figure 1-3).

BHT 2 extended $4.3 \mathrm{~m}(14.1 \mathrm{ft}$.) and was terminated at $1.45 \mathrm{~m}$ (4.76 ft.) below the surface. In both trench profiles, Feature 2, a shallow, basin-shaped concentration of concrete, 
Redacted Image

Figure 4-3. Gas line marking west of BHT 1 (facing west); north-south alignment marked in yellow spray paint.

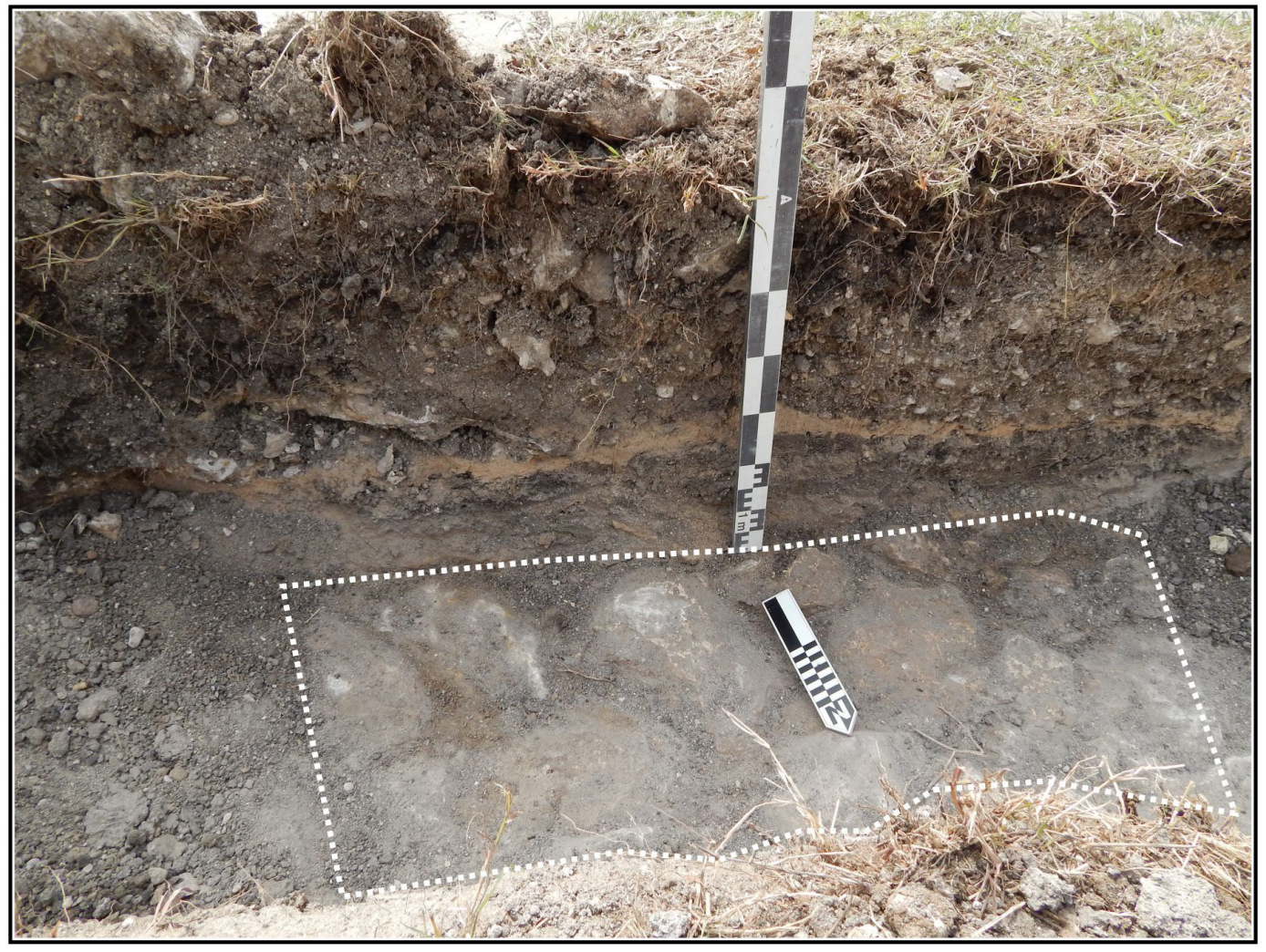

Figure 4-4. South profile of BHT 1. Feature 1 in foreground in dashed white outline. 


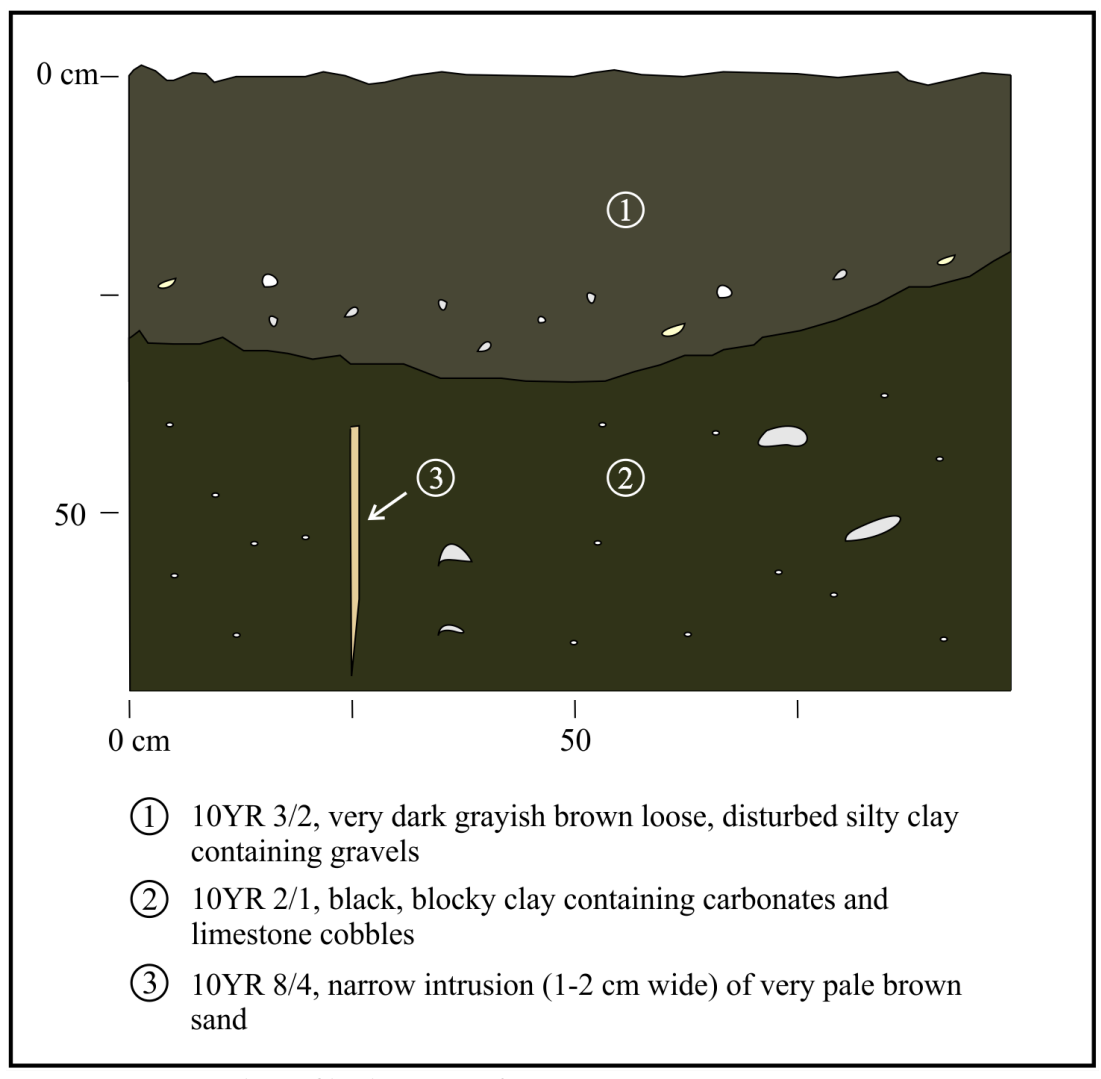

Figure 4-5. North profile drawing of BHT 1, $1 \mathrm{~m}$ segment.

tile, and large amounts of rock and gravel, was documented from $30-60 \mathrm{~cm}(11.8-23.6$ in.) below the surface near the northern edge of the trench. The feature spanned more than $1 \mathrm{~m}$ (3.3 ft.) in the eastern profile but narrowed in the west, disappearing into the northwest corner (Figure 4-6). The feature, dominated by construction material, is likely recent. Four layers were recorded in the trench profile (Figure 4-7). Layer 1 was similar to Layer 1 in BHT 1 and contained loose, dark brown (10YR 3/3) silty clay with roots. This layer appeared disturbed and extended from 30-35 $\mathrm{cm}$ (11.8-13.8 in.) below the surface. Layer 2 extended from $30-50 \mathrm{~cm}$ (11.819.7 in.) below the surface and contained dark brown (10YR $3 / 3$ ) gravelly clay. Layer 3, from $50-110 \mathrm{~cm}$ (19.7-43.3 in) below the surface, contained blocky, very dark gray (10YR 3/1) clay. Below $110 \mathrm{~cm}$ (43.3 in.) to the trench floor, Layer 4 was distinguished from Layer 3 by a significant increase in carbonates. One piece of debitage and one fragment of clear glass were observed in the backdirt but not collected. No artifacts, aside from the construction debris in Feature 2, were observed in either profile.

BHT 3 was excavated perpendicular to BHT 1 (see Figure 4-2) in order to further investigate Feature 1. The trench was oriented north-south. It extended $2.9 \mathrm{~m}(9.5 \mathrm{ft}$.) and was excavated to a maximum depth of $85 \mathrm{~cm}$ (33.5 in.) below the surface. A rough limestone block wall, articulating with the stone-lined floor uncovered in Trench 1, was uncovered. The top of the wall, encountered at $27 \mathrm{~cm}$ (10.6 in.) below the surface, appeared to be disturbed. Several loose stones were in the soil above it, and the northern edge was obscured by collapse. The soil profile was similar to the northern profile of BHT 1, and additional profiles were not drawn due to the proximity of the trenches. One possible ox or mule shoe was observed in the backdirt, but it was not collected (see Appendix A).

\section{Features Recorded in Project Area 1}

Two features were recorded during the course of backhoe trenching in Project Area 1. Feature 1 was an architectural limestone feature documented in BHT 1 and identified as a section of the Upper Labor Acequia (41BX1273). Feature 2 was a basin-shaped, rubble-filled feature documented in BHT 2. The feature is likely a construction dump. Figure 4-8 shows the features and trenches in Project Area 1.

\section{Feature 1}

Feature 1 was documented in BHTs 1 and 3, spanning the entirety of BHT 1 . The feature consisted of a relatively flat floor of rough limestone cobbles, articulated with a wall constructed of rough-cut limestone blocks (Figures 4-9 and 4-10). A layer of sandy soil above the floor was noted (Figure 4-11). To the south, the layers of the soil profile indicate 


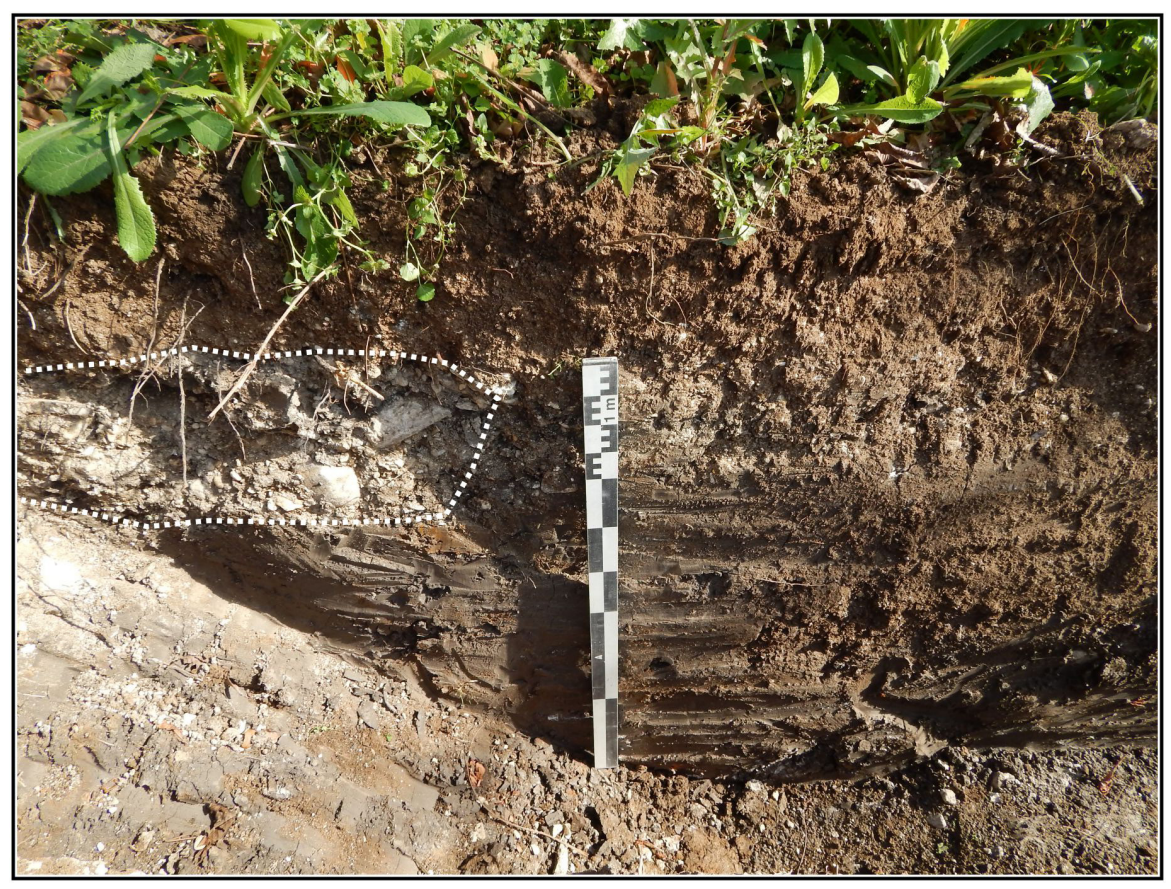

Figure 4-6. East profile of BHT 2. Feature 2 (left) demarcated by dashed white outline.

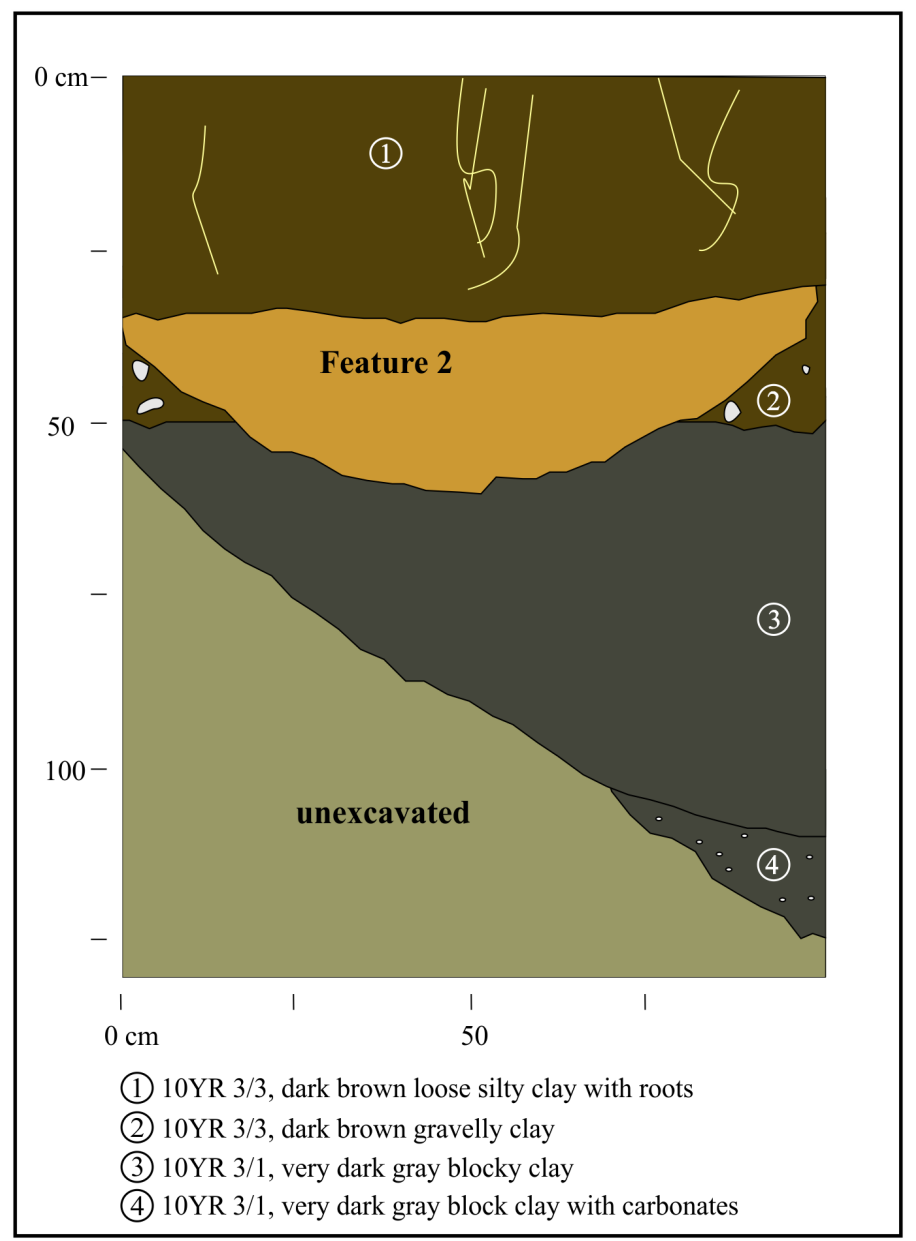

Figure 4-7. East profile of BHT 2, $1 \mathrm{~m}$ segment. Roots are shown as yellow lines. 
Redacted Image

Figure 4-8. Trench and feature locations within Project Area 1.

multiple fill episodes of gravel and sand within the acequia channel. Examination of the profile at the eastern end of BHT 1 suggests these fill episodes begin about $30 \mathrm{~cm}$ (11.8 in) from the northern wall of the trench. Additional images of Feature 1 are presented in Appendix A.

Feature 1 extended east and west beyond the trench and south under the sidewalk. The wall is approximately $80 \mathrm{~cm}$ (31.5 in.) across, although the collapsed northern edge makes the exact width difficult to determine (Figure 4-12). The feature spans more than $1.7 \mathrm{~m}$ (5.6 ft.) north-south, and it appears to run eastwest following Fredericksburg Road. This feature roughly aligns with the projected path of the Upper Labor Acequia depicted on the 1911 Sanborn map, but the feature is located somewhat south of the acequia's projected alignment on the 1904 Sanborn map (see Figures 1-3 and 1-4). The feature's location, its construction, and its interior stratigraphy suggest it is a segment of the Upper Labor Acequia (41BX1273), which is a designated National Historic Civil Engineering Landmark and eligible for the NRHP. 


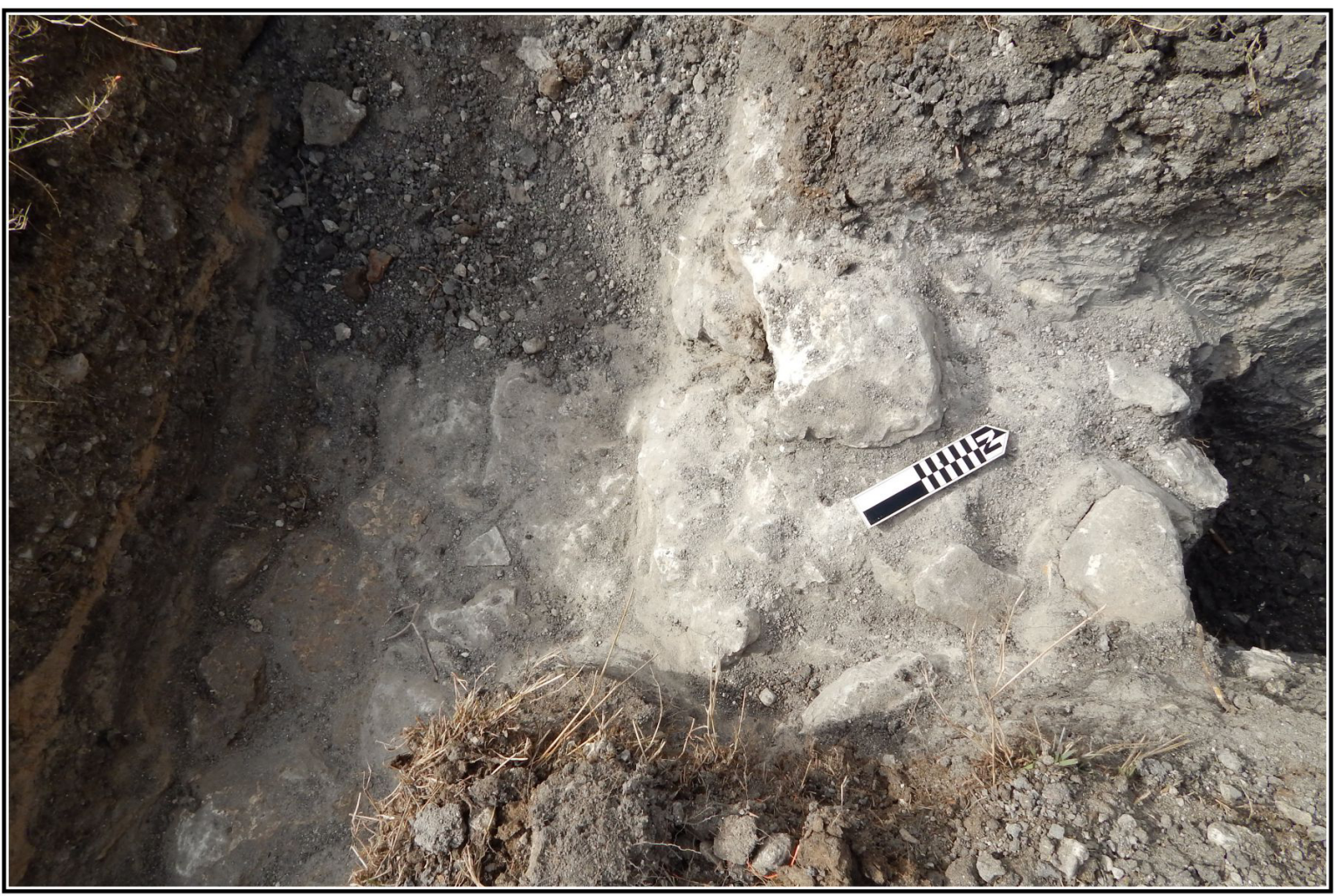

Figure 4-9. Feature 1 facing west. Wall to the right and cobble floor to the left.

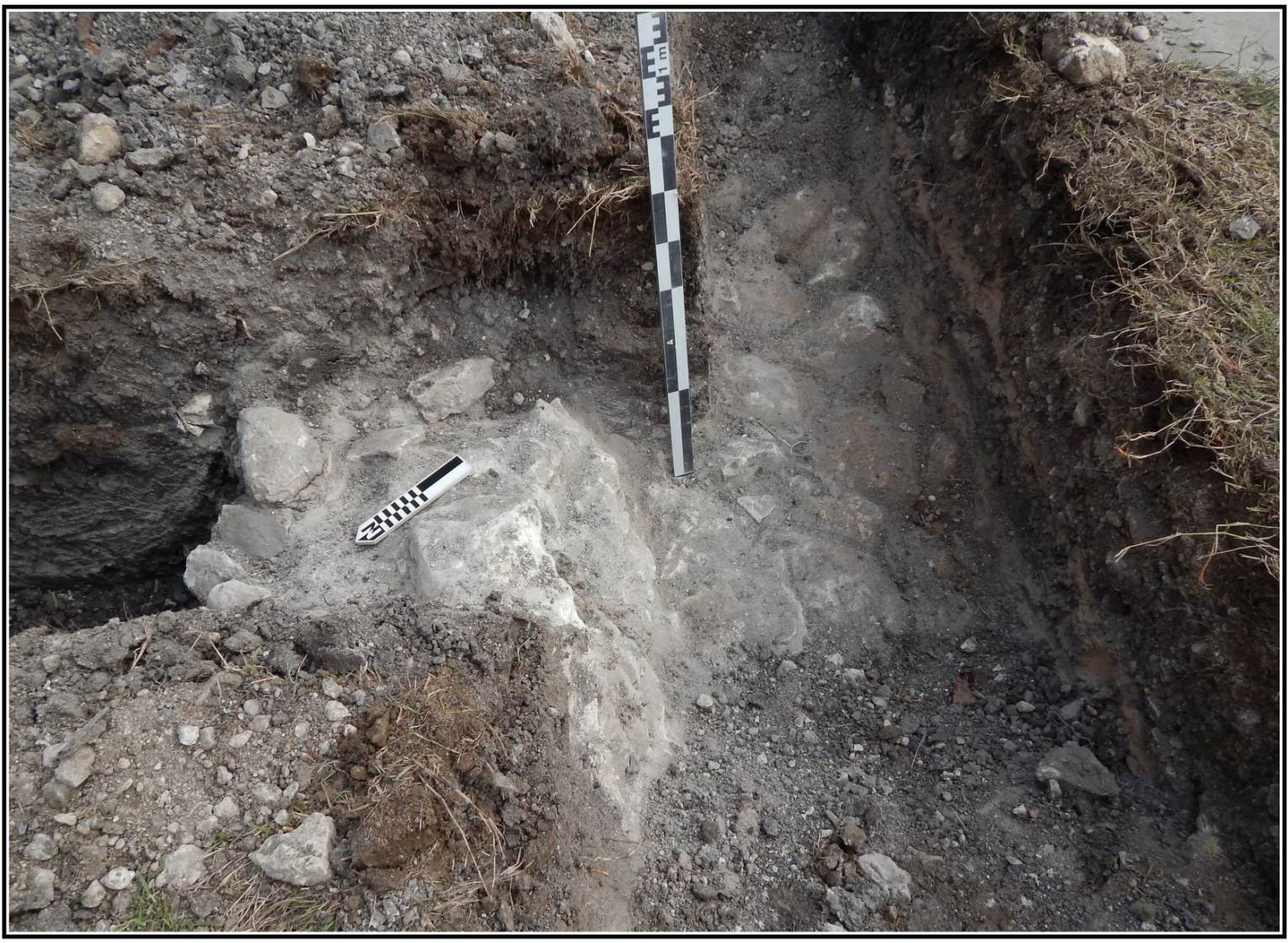

Figure 4-10. Feature 1 facing east. Wall to the left and cobble floor to the right. 


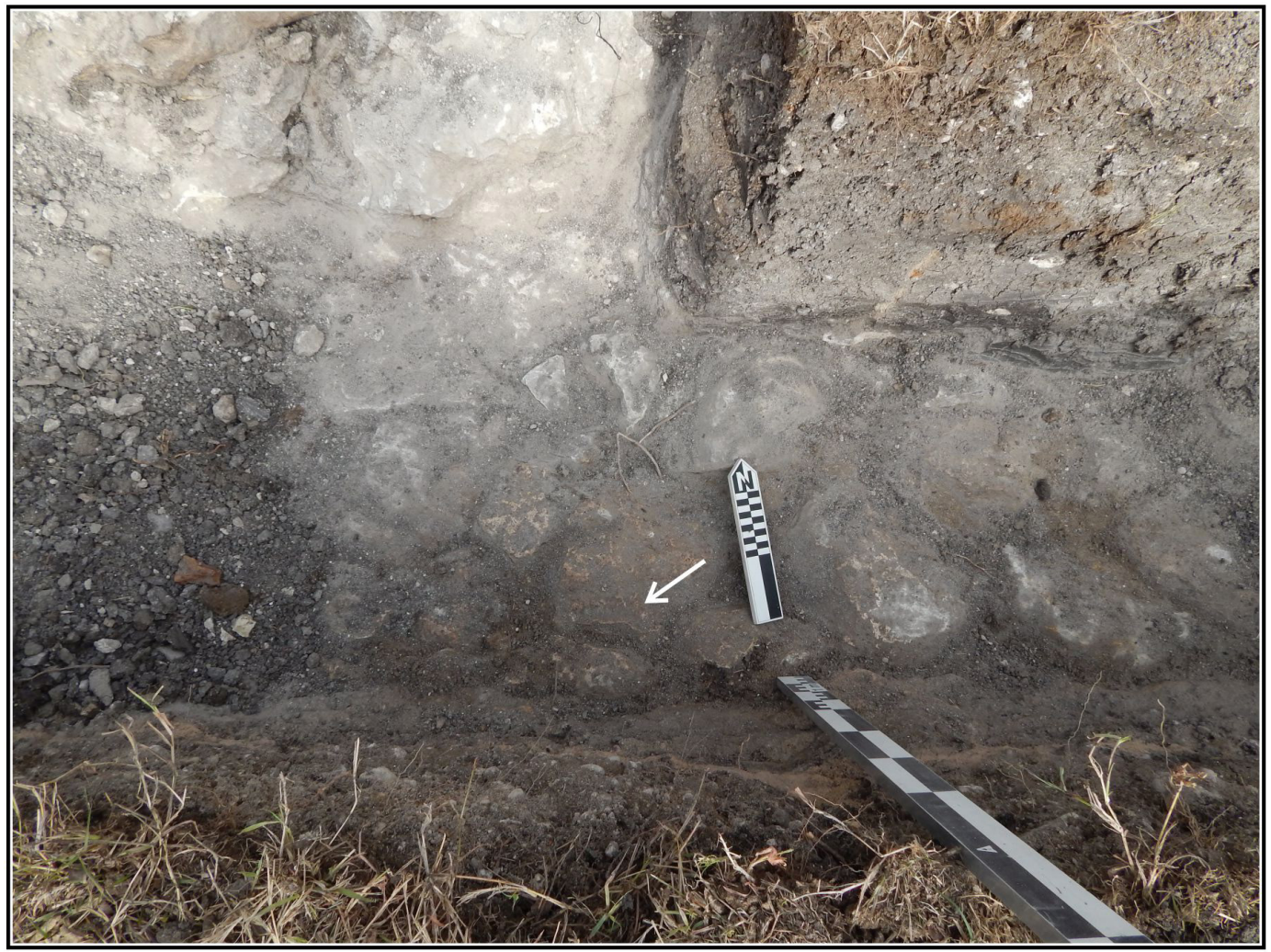

Figure 4-11. Feature 1. Note sandy layer above cobble floor.

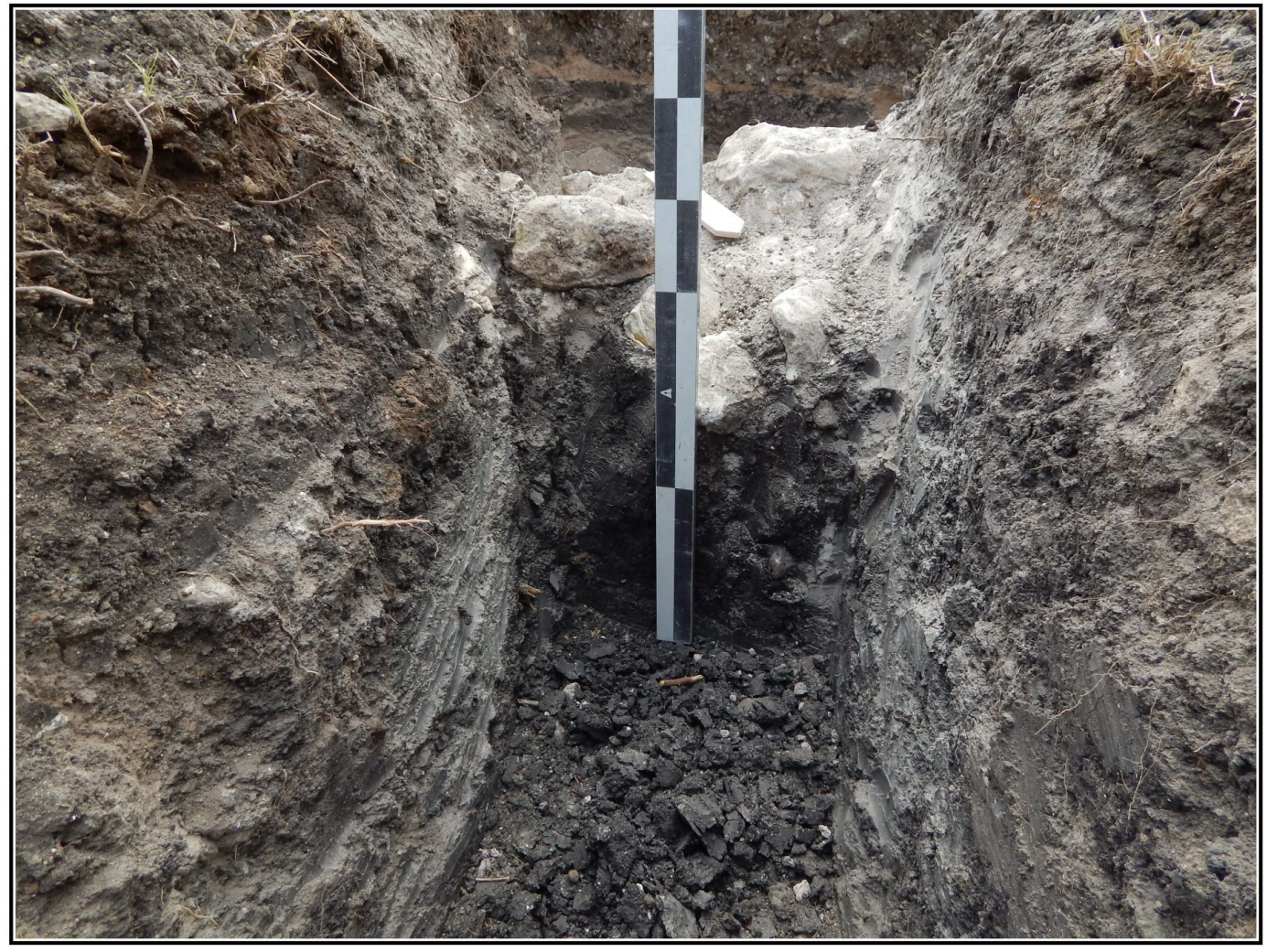

Figure 4-12. Northern profile of Feature 1 within BHT 3 (facing south). Note partial wall collapse. 
The only artifact observed during the excavations of BHTs 1 and 3 is the ox or mule shoe identified in the backdirt from BHT 3 (see Appendix A). It was not collected.

\section{Feature 2}

Feature 2 was documented in the northeast corner of BHT 2 (see Figure 4-2). The feature is basin shaped and spans at least $60-\mathrm{x}-70 \mathrm{~cm}$ (23.6-x-27.6 in.). It extends from $30-60 \mathrm{~cm}$ (11.8-23.6 in.) below the surface (see Figures 4-6 and 4-7). The feature is significantly wider in the eastern profile than in the west, suggesting an oblong shape. The feature contains concrete, tile rubble, gravel, and limestone cobbles. The soil matrix is mottled dark gray (10YR 4/1) to dark grayish brown (10YR 4/2) sandy, gravelly clay. The construction material within the trench suggests that it dates to the twentieth century at the earliest. In the United States, the use of concrete in construction did not become common in architecture until the end of the nineteenth century (Addis and Bussell 2008), and the first concrete road in the United States was not constructed until 1893 in Ohio (Snell and Snell 2002). Additionally, the 1904 Sanborn map of the area shows no use of these materials in the construction of nearby buildings, and nearby homes are primarily constructed of wood (Sanborn 1904). The closure of the Upper Labor Acequia occurred in 1896 (Cox 2005). While it is roughly in alignment with the projected path of the Upper Labor Acequia on the 1904 Sanborn map (see Figure 1-3), the lack of a distinct eastwest alignment, later affiliation of the construction material, and shallowness of the feature suggest that this not the acequia but a likely construction dump. Aside from the noted construction material, no artifacts associated with this feature were observed.

\section{Project Area 2}

Project Area 2 is located just north of Project Area 1 at 712 W. Laurel Street (Figure 4-13). Two trenches, BHTs 4 and 5, were excavated in Project Area 2 (Figure 4-14). These were positioned to intersect the potential north-south alignment of the San Pedro Acequia depicted along the western boundary of Project Area 2 (see Figures 1-4 and 3-1). Feature 3 was identified in BHTs 4 and 5, and Feature 4 was identified in BHT 4 (see Figure 4-14).

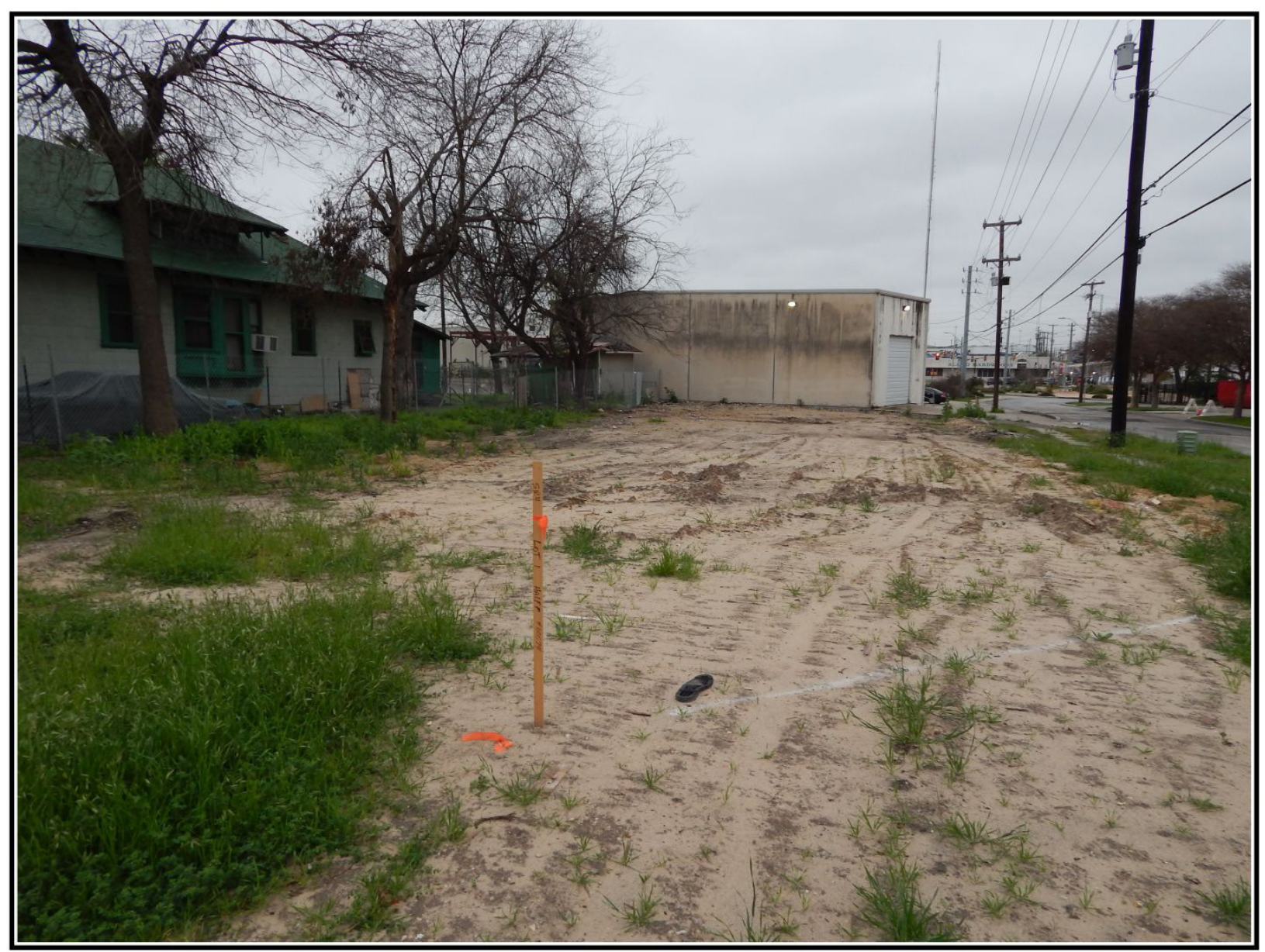

Figure 4-13. Project Area 2, prior to excavation (facing west). Southern property boundary is the chain-link fence with the western boundary defined by the structure and northern boundary inside the utility poles. 
Redacted Image

Figure 4-14. Trench locations within Project Area 2.

BHT 4 was excavated along the western property boundary of Project Area 2 (see Figure 4-14). The trench extended 11.1 m (36.4 ft.) north-south, was $90 \mathrm{~cm}$ (35.4 in.) in width, and reached a depth of $120 \mathrm{~cm}$ (47.2 in.). It was determined that the entirety of BHT 4 was within the channel of the San Pedro Acequia, and the trench was designated Feature 3. Feature 4 was recorded in BHT 4. Feature 4 is a white clay deposit within the acequia channel.
The soil profile documented within the trench included three layers with borders that were somewhat irregular (Figures 4-15, 4-16, and 4-17). Layer 1 was $0-47 \mathrm{~cm}$ (0-18.5 in.) below the surface and consisted of gravelly clay mottled very dark grayish brown (10YR 3/2) and yellowish brown (10YR 5/6). Layer 2 was 47-75 cm (18.5-29.5 in.) below the surface and consisted of very dark grayish brown (10YR 3/2) blocky clay. Layer 3 was $75-105 \mathrm{~cm}$ (29.5-41.3 in.) below 


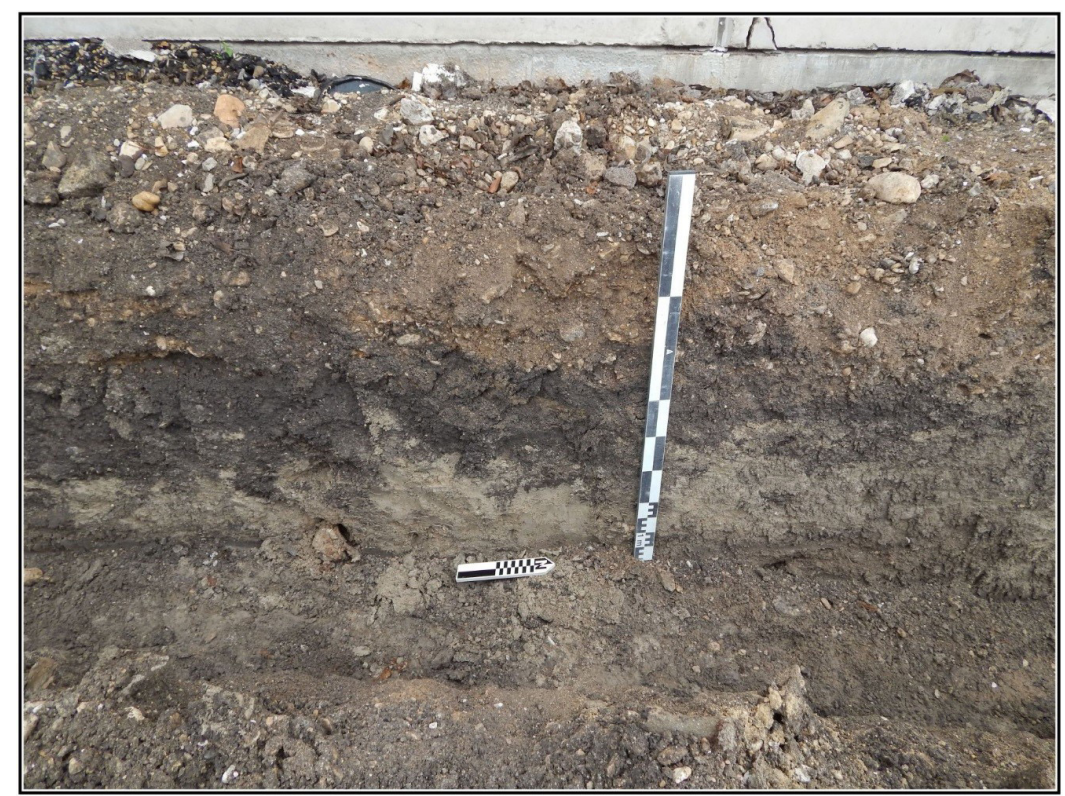

Figure 4-15. Western profile of BHT 4.

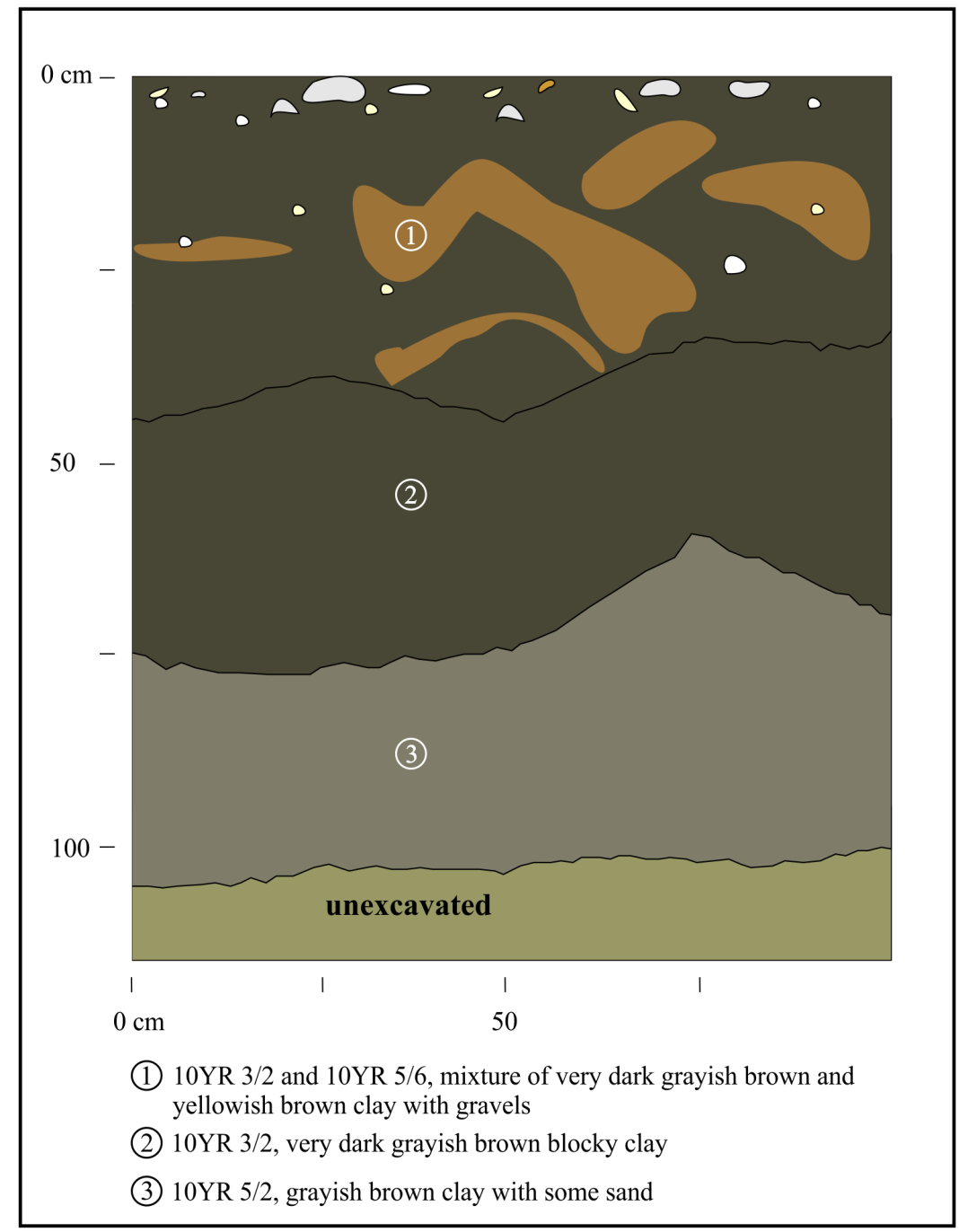

Figure 4-16. West profile of BHT 4, $1 \mathrm{~m}$ segment. 


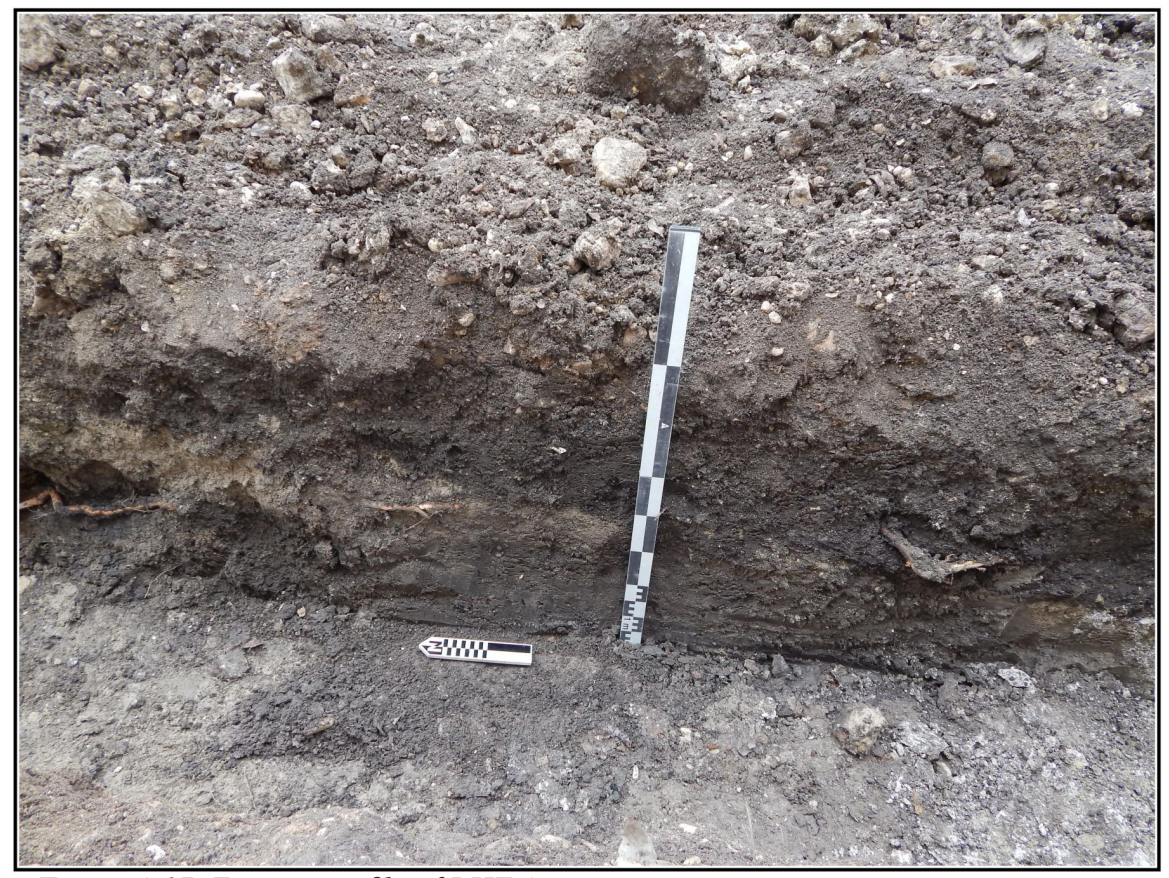

Figure 4-17. Eastern profile of BHT 4.

the surface and consisted of grayish brown (10YR 5/2) clay with some sand. This layer was much more prominent in the western profile than the eastern profile, and in some places in the eastern profile, the layer thinned significantly to the point of disappearing. A small quantity of potentially diagnostic artifacts, including ceramics, glass, and a wire nail, was collected from this trench. These artifacts will be discussed in more detail at the end of this chapter.

BHT 5 was excavated perpendicular to the southern end of BHT 4 (see Figure 4-14). The trench was intended to intersect the alignment of the San Pedro Acequia if it was located within Project Area 2 east of its projected alignment (see Figure 4-14). BHT 5 extended $5 \mathrm{~m}$ (16.4 ft.) east-west. It was $85 \mathrm{~cm}$ (33.5 in.) in width, and it reached a maximum depth of $125 \mathrm{~cm}$ (49.2 in). A limestone block and evidence of an unlined, basin-shaped channel were identified in the northern trench profile (Figure 4-18). It was determined that this was a part of Feature 3. Figure 4-19 shows the BHT 5 profile outside of Feature 3.

A small quantity of diagnostic cultural material, including ceramics and glass, was collected from this trench. This material will be discussed in greater detail near the end of the chapter, and photographs of selected artifacts are provided in the Appendix A.

\section{Features Recorded in Project Area 2}

Two features were identified in Project Area 2. Feature 3 was a segment of the San Pedro Acequia (41BX337), and Feature
4 was a white clay stain documented within the acequia channel (Feature 3). Figure 4-20 presents the location of the features within BHTs 4 and 5.

\section{Feature 3}

This feature was initially documented within BHT 5, but it was determined to be present within the whole of BHT 4 as well (see Figure 4-20). Feature 3 was originally defined by the presence of a smooth, finely cut limestone block encountered within BHT 5, with a thin layer of small limestone cobbles below the block. Examination of the area below the stone in BHT 5 made it clear that only one course of stone is present. In the northern profile of BHT 5, a basin-shaped channel west of the limestone block was present (Figure 4-21). The soil profile within the channel was similar in appearance to the soil profile documented within BHT 4, while soil profile east of the limestone block showed less stratification (see Figures 4-18, 4-19, and 4-21). The defined basin-shaped feature in the profile is present at $30 \mathrm{~cm}$ (11.8 in.) below the surface, but the stone was not encountered until $88 \mathrm{~cm}$ (34.65 in) below the surface. The bottom of the stone extends to $110 \mathrm{~cm}(43.3$ in.) below the surface. The documented extent of the feature was $1.1 \mathrm{~m}$ (3.6 ft.) extending north-south and $90 \mathrm{~cm}(35.4$ in.) east-west. However, the feature extends north, south, and west of the section documented within BHTs 4 and 5 . The nature, alignment, and location of the feature along the property line suggest it is a segment of the San Pedro Acequia (41BX337). The soil profile resembles the description of the unlined ditch recorded by CAR just north of the project area in 1986, with the exception of the asphalt fill noted during that project (Cox 1993). The west wall of the acequia, if still 


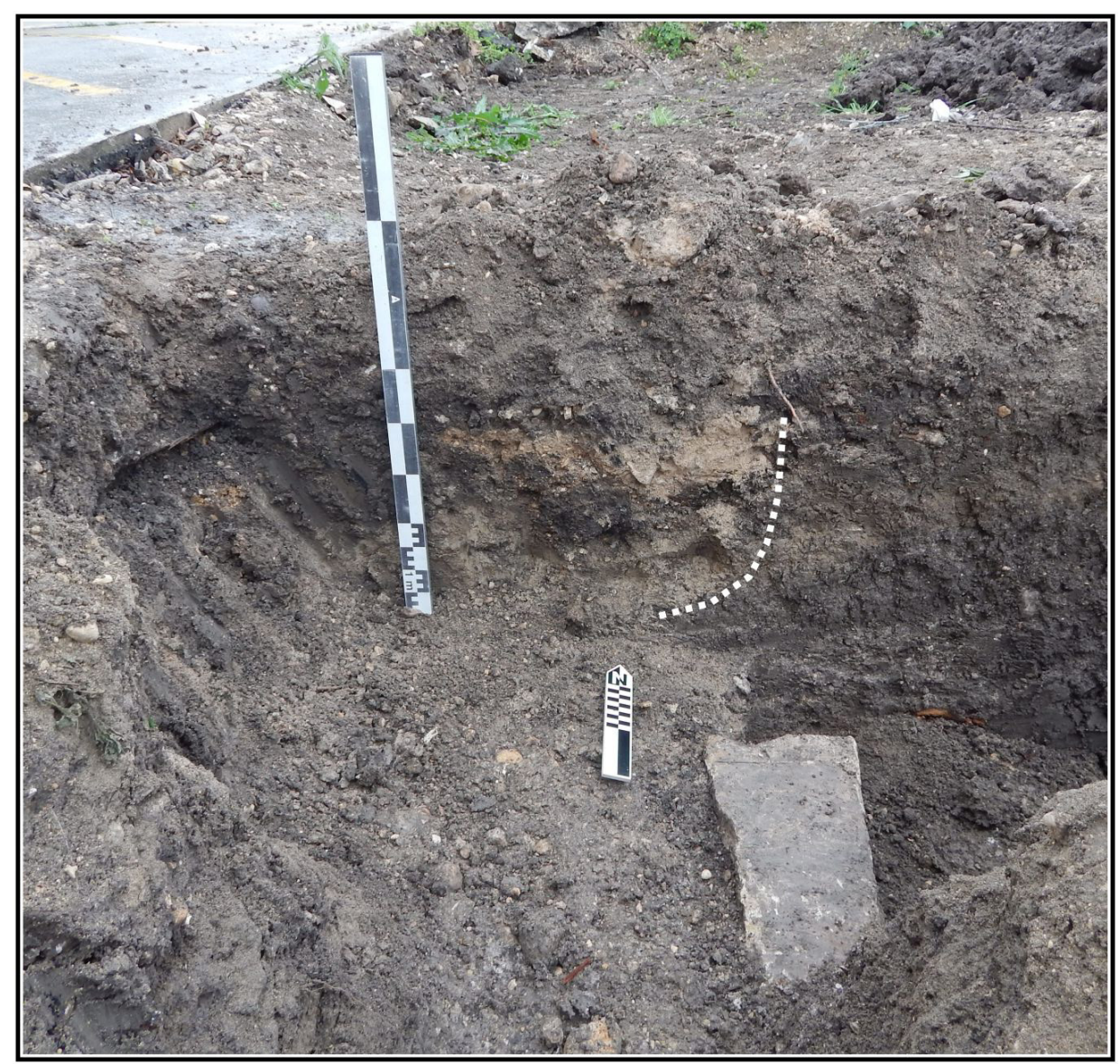

Figure 4-18. Northern profile of BHT 5. Dashed white line demarcates soil change associated with Feature 3.

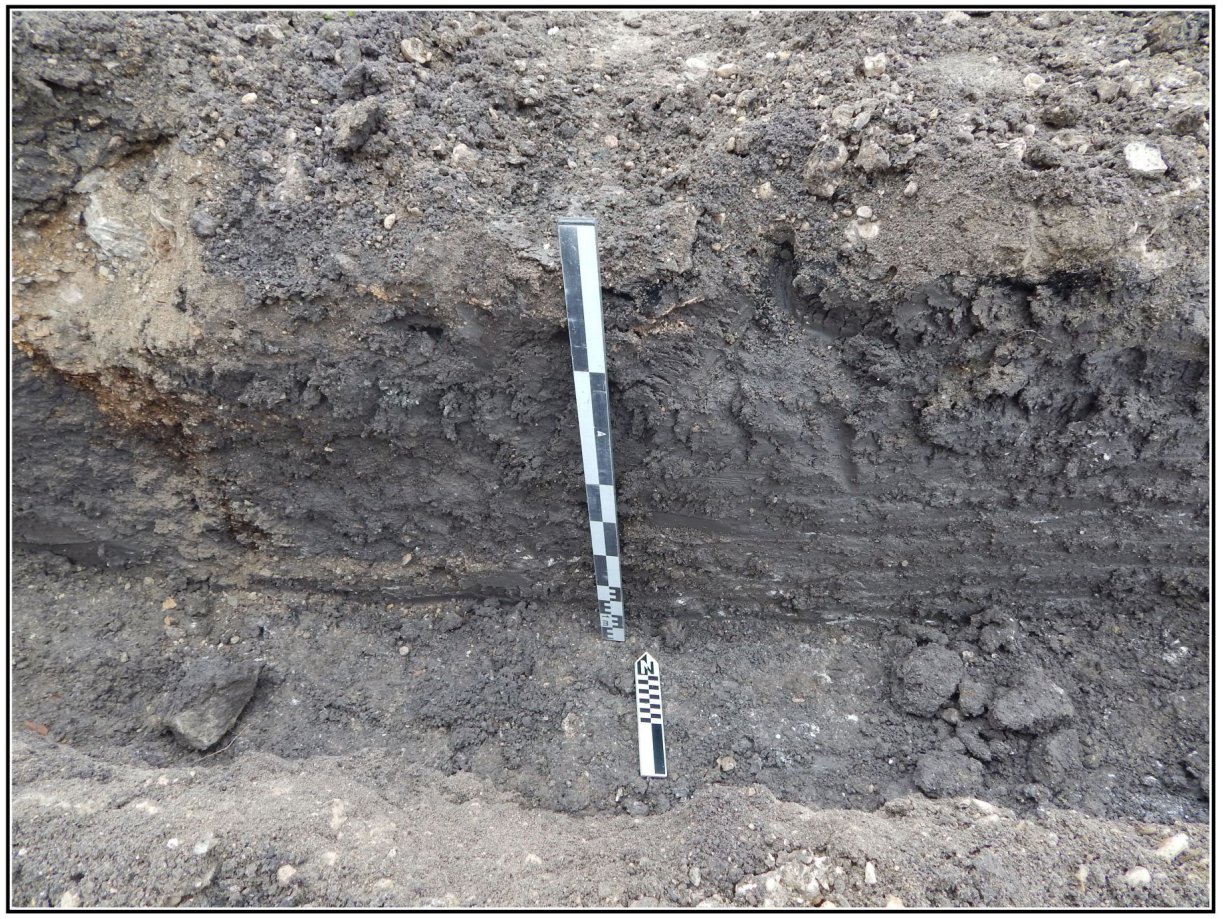

Figure 4-19. Northern profile of BHT 5, east of Feature 3. 
Redacted Image

Figure 4-20. Location of trenches and features within Project Area 2. Note that the buildings within the project area displayed on the aerial were not present at the time of excavation.

present, is likely west of the Project Area 2 on VIA-MTA property. The highly finished nature of the stone (see Figures 4-21, 4-22, and Appendix A) suggests that it may have been a later modification, prior to the closing of the acequia in 1912 (Cox 2005). If this is the case, it is likely that this segment of the acequia was originally unlined. The construction of Feature 3 is significantly different than the limestone cobble construction of Feature 1 in Project Area 1.
Five layers were recorded in the north trench profile that contained Feature 3 (Figure 4-23). Layer 1 was $0-25 \mathrm{~cm}(0-$ 9.8 in.) below the surface and consisted of very dark gray (10YR 3/1) soft, gravelly, clumpy clay. Layer 2 was 25-62 $\mathrm{cm}(9.8-24.4 \mathrm{in}$.) below the surface and consisted of dark gray (10YR 4/1) compact clumpy clay. Layer 3 was $62-82$ $\mathrm{cm}$ (24.4-32.3 in.) below the surface and consisted of grayish brown (10YR 5/2) compact, blocky clay with some sand. 


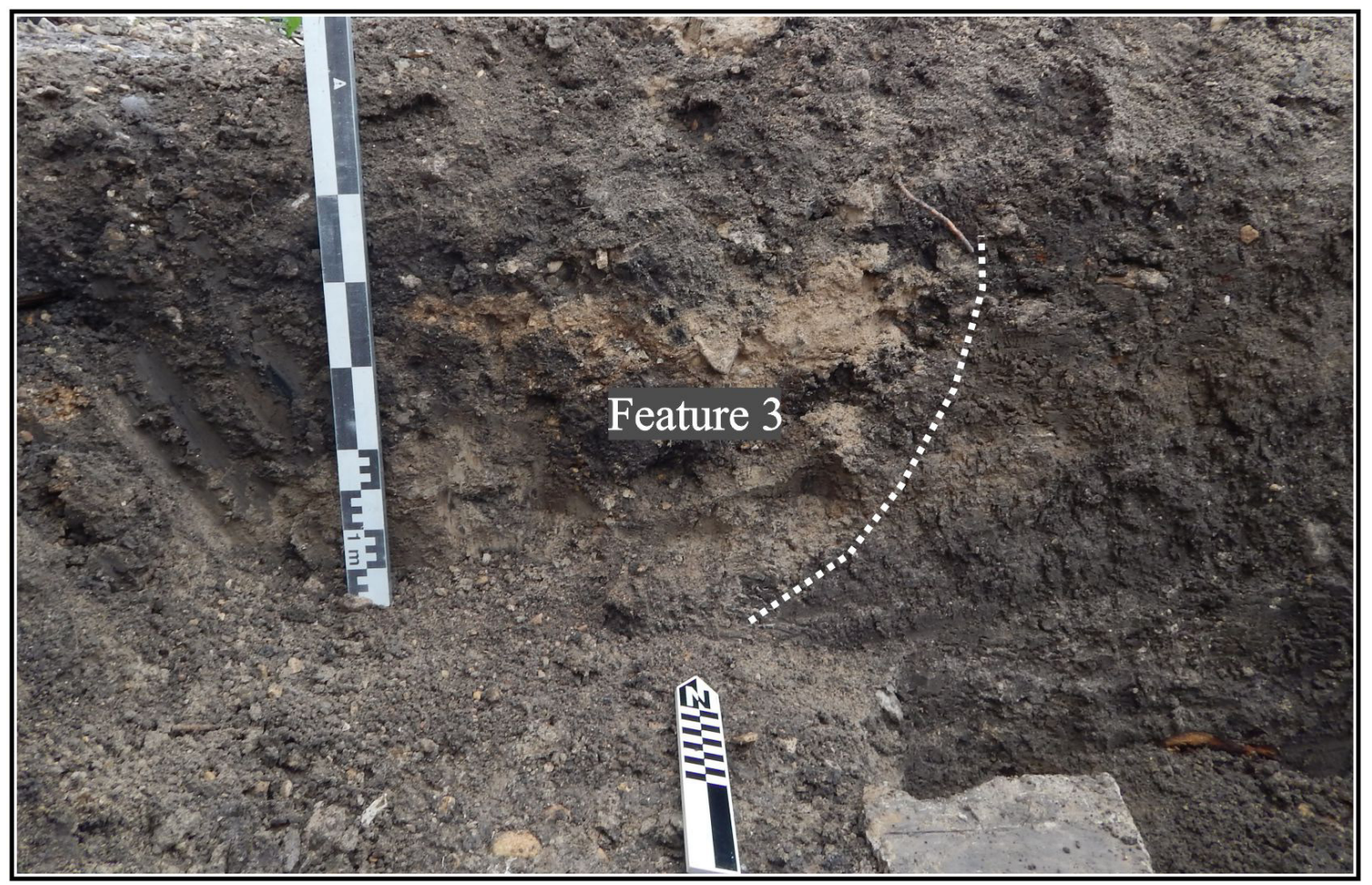

Figure 4-21. Feature 3. Note soil change west of limestone block (facing north). Dashed white line demarcates shift in soil profile.

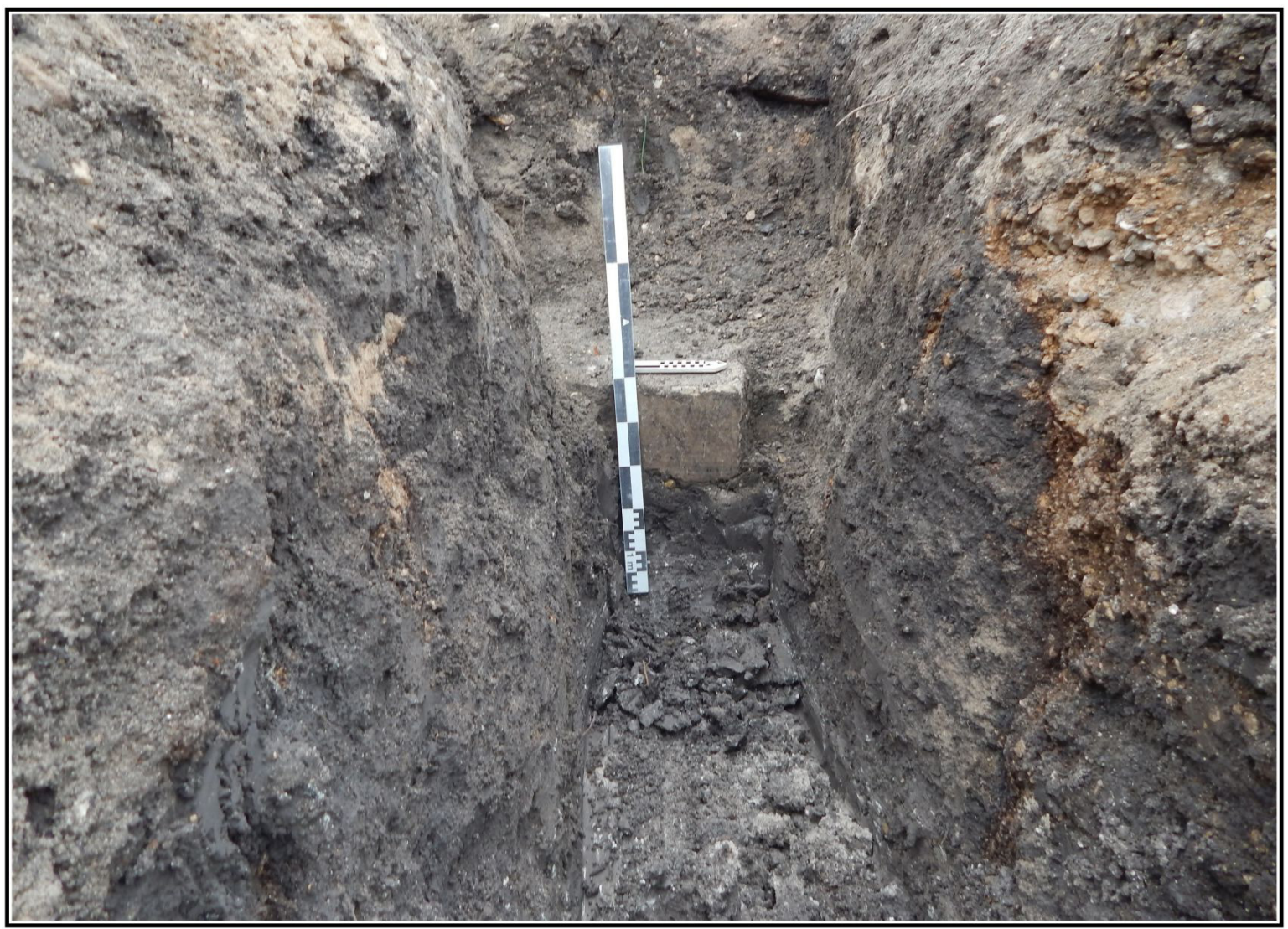

Figure 4-22. East profile of Feature 3. Note single course of stone. 


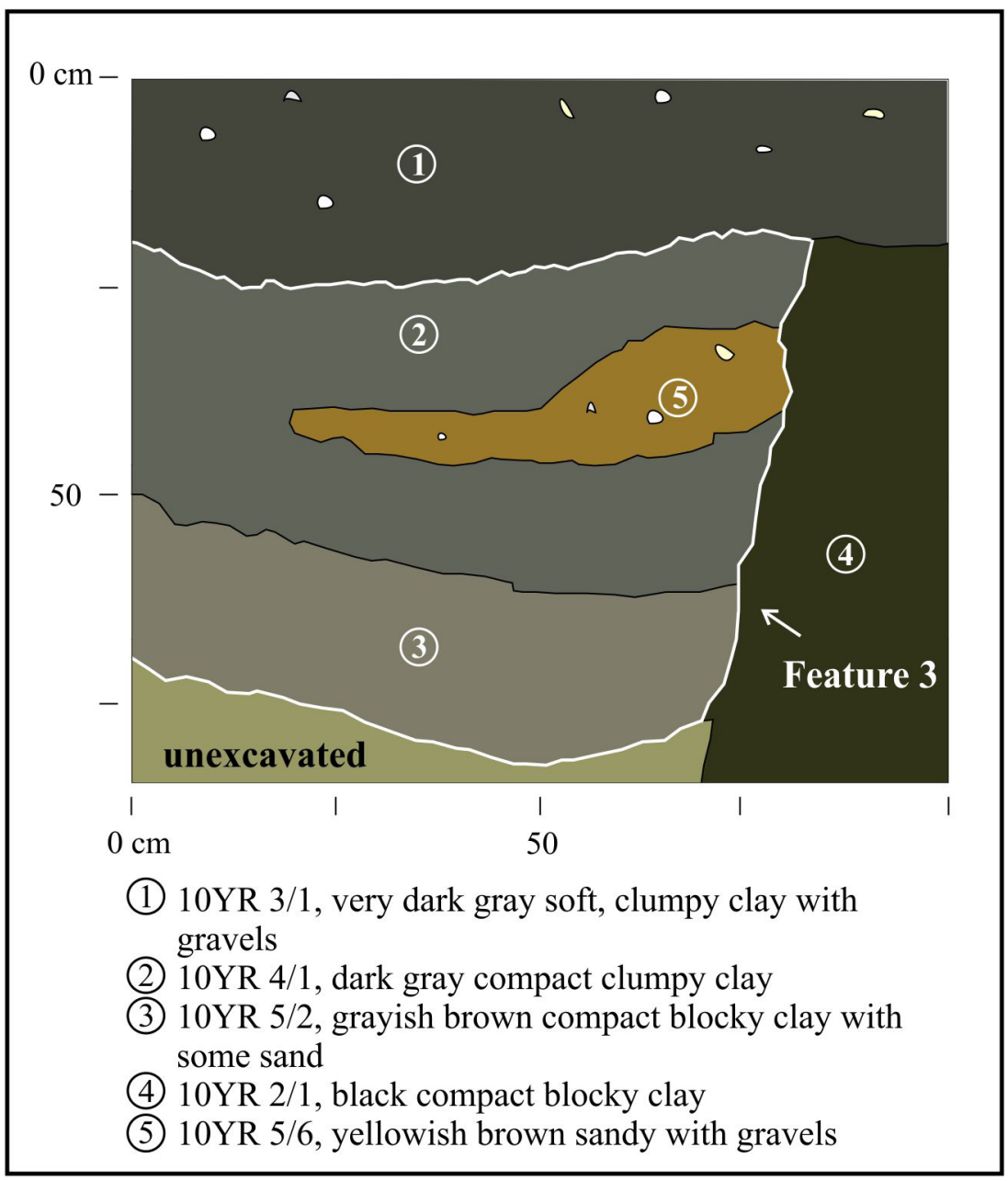

Figure 4-23. Northern profile of BHT 5 showing Feature 3 (outlined in white).

Layer 4 was $25-90 \mathrm{~cm}(9.8-35.4$ in.) below the surface and consisted of black (10YR 2/1) compact, blocky clay. Layer 5 was 30-45 cm (11.8-17.7 in.) below the surface and consisted of a yellowish brown (10YR 5/8) sandy intrusion with gravels. The boundaries between Layer 2, within the feature, and Layer 4, outside the feature, were not well defined, and it is possible that the soil color difference is primarily due to soil mixing between layers within the feature.

\section{Feature 4}

Feature 4 is a white clay stain documented within the acequia channel (Feature 3) near the bottom of BHT 4 (Figure 4-24; see also Figure 4-20). This may represent the use of the area as some sort of dump before the acequia was closed. The feature was irregular in shape with defined edges. It was defined at $70 \mathrm{~cm}(27.6 \mathrm{in}$.) below the surface and reached a depth of at least $115 \mathrm{~cm}$ (45.3 in.) below the surface. The feature was $118 \mathrm{~cm}$ (46.5 in.) in length and $55 \mathrm{~cm}$ (21.65 in.) in width. The feature contained no artifacts.

\section{Artifacts Collected from Project Area 2}

All artifacts collected from Project Area 2 were associated with Feature 3. Only artifacts considered temporally diagnostic were collected. Collected artifacts included three ceramic sherds, three glass fragments, one complete glass bottle, and a wire nail (Table 4-1). Photographs of several of the collected items are provided in the Appendix A.

The ceramic sherds consisted of an undecorated porcelain rim, a stoneware body fragment, and a Galera body fragment (see Appendix A). In Texas, stoneware dates to 1850-1900. Galera, a type of Spanish Colonial lead glaze, can date as early as 1722 and as late as the present day (Fox and Ulrich 2008:50-51; THC 2006). The complete glass bottle collected from the bottom of the trench would have rested within the acequia channel (see Appendix A). The manufacturing marks on the bottle include a tooled oil finish and a post-molded base. The tooled finish of the bottle is evident from the 


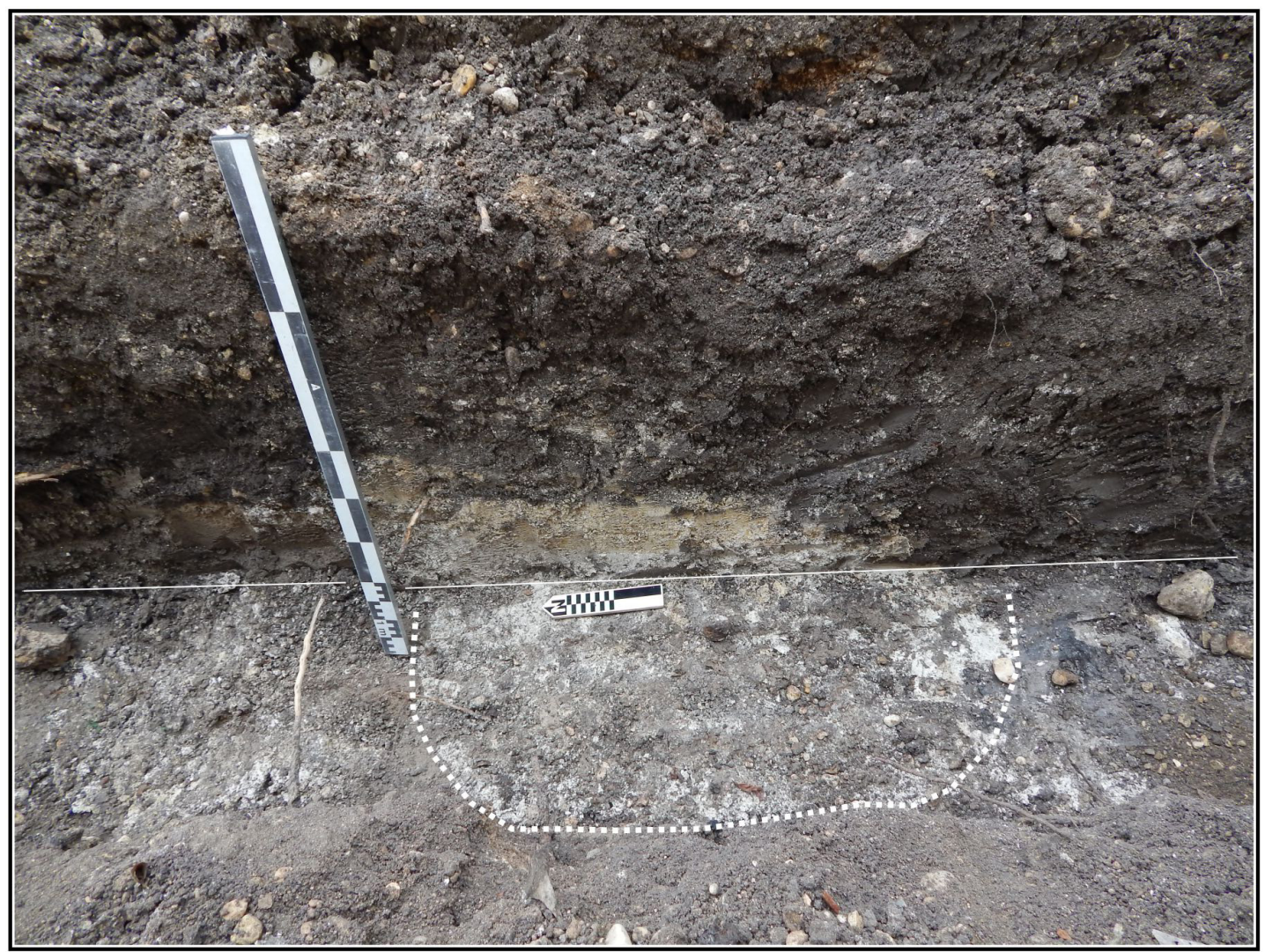

Figure 4-24. Feature 4 within BHT 4 (facing east). Dashed white line demarcates feature boundary, and solid white line separates trench wall from trench floor.

fading side-mold seam at the neck and the faint concentric tooling marks. The shift to the use of tooled finishes in glass bottles in the United States began in the 1870s, and this type of finish predominates by the 1890s (Lindsey 2020), until the transition to machine-made bottles by 1914-1915. Postbottom molded bottles in the United States range from the 1840s to the early 1900s (Lindsey 2020). Wire nails became the dominant nail type in the United States around 1910 (Fontana et al. 1962). Broadly, the artifacts recovered from
Feature 3 are consistent with material from the late 1800s to the early 1900s, although individual artifacts, such as the Galera sherd, could potentially date earlier. The acequia was known to have been in operation from 1735 to 1912 (Cox 2005). The artifacts found within the acequia may date the years just prior to its closing, when cleanings were more infrequent and the acequia may at times have run dry due to decreased water flow in the San Antonio River and San Pedro Creek (Cox 2005). 
Table 4-1. Artifacts Collected from Project Area 2

\begin{tabular}{|c|c|c|c|c|c|c|}
\hline Provenience & $\begin{array}{l}\text { Depth } \\
\text { (cmbs)* }\end{array}$ & Superclass & Class & Description & Count & Weight (g) \\
\hline BHT 4 backdirt & $0-120$ & Ceramics & $\begin{array}{l}\text { European } \\
\text { Porcelain }\end{array}$ & Undecorated, lip/rim & 1 & \\
\hline BHT 4 backdirt & $0-120$ & Ceramics & $\begin{array}{l}\text { European } \\
\text { Stoneware }\end{array}$ & $\begin{array}{l}\text { Albany slip interior, } \\
\text { salt glaze exterior, body }\end{array}$ & 1 & \\
\hline BHT 4 backdirt & $0-120$ & Glass & $\begin{array}{l}\text { Container/ } \\
\text { Vessel }\end{array}$ & $\begin{array}{c}\text { Bottle, brown, base, heavy patina, } \\
\text { bubbles, no mold seams }\end{array}$ & 1 & 20.6 \\
\hline BHT 4 backdirt & $0-120$ & Metal & Nails & Wire & 1 & 5 \\
\hline BHT 5 backdirt & $0-125$ & Ceramics & $\begin{array}{c}\text { Spanish } \\
\text { Colonial Lead } \\
\text { Glazed }\end{array}$ & Galera, body & 1 & \\
\hline BHT 5 backdirt & $0-125$ & Glass & $\begin{array}{l}\text { Container/ } \\
\text { Vessel }\end{array}$ & $\begin{array}{c}\text { Amber, body, textured, } \\
\text { no mold seams, no bubbles }\end{array}$ & 1 & 38.5 \\
\hline BHT 5 backdirt & $0-125$ & Glass & $\begin{array}{l}\text { Container/ } \\
\text { Vessel }\end{array}$ & $\begin{array}{l}\text { 7-up green, wide rim, bubbles, } \\
\text { textured/partially melted }\end{array}$ & 1 & 4 \\
\hline BHT 4 bottom & 105 & Glass & $\begin{array}{l}\text { Container/ } \\
\text { Vessel }\end{array}$ & $\begin{array}{l}\text { Bottle, amber, complete, tooled oil } \\
\text { finish, post-molded, flask shape, } \\
\text { bubbles, textured surface }\end{array}$ & 1 & 27.6 \\
\hline
\end{tabular}

$* \mathrm{cmbs}=\mathrm{cm}$ below the surface 


\section{Chapter 5: Summary and Recommendations}

On January 21 and February 19, 2020, CAR conducted an archaeological investigation with backhoe trenching of two lots, one at 209 E. Fredericksburg Road (Project Area 1) and a second at 712 W. Laurel Street (Project Area 2). Both lots are proposed locations for development as new VIA-MTA employee parking lots. Review of historic maps prior to the project indicated the potential to encounter two significant historic sites, the San Pedro Acequia (41BX337) and the Upper Labor Acequia (41BX1273) within Project Area 1 and another segment of the San Pedro Acequia (41BX337) within Project Area 2 (see Figures 1-3, 1-4, 2-1, and 2-2). Both sites are designated as National Historic Civil Engineering Landmarks, and the San Pedro Acequia (41BX337) is listed as eligible for the NRHP and as a SAL (THC 2020).

In total, three backhoe trenches were excavated within Project Area 1, and two features were documented. Feature 1 was a section of limestone rubble floor and wall documented within BHTs 1 and 3. This feature has been identified as a section of the Upper Labor Acequia (41BX1273). Feature 2 was a basin-shaped deposition of cement and concrete rubble documented within BHT 2 . This feature likely represents a twentieth-century event and has no research value.

In Project Area 2, two backhoe trenches were excavated, and two features were documented within these trenches. Feature 3 consisted of a basin-shaped channel identified in the soil profile of BHT 5 and associated limestone block. After examination of the soil profiles of both trenches, it was clear the whole of BHT 4 was excavated within this channel. Feature 4 is a white clay stain located within the boundaries of Feature 3.

Feature 1, a section of the Upper Labor Acequia (41BX1273), was documented within BHTs 1 and 3. It consisted of the limestone cobble floor spanning the floor of BHT 1 , articulated with a wall of rough limestone blocks documented in BHT 3. The feature exhibits the east-west orientation of the Upper Labor Acequia depicted on archival maps of the area (see Figures 1-3, 1-4, 2-1, and 2-2) and closely aligns with the projected path of the acequia shown in the 1911 Sanborn map (see Figure 1-4). The southern profile of the trench suggests multiple fill episodes within the acequia's channel. The feature continues east, west, and south of BHT 1. While the intersection of the San Pedro Acequia (41BX337) and Upper Labor Acequia (41BX1273) was not encountered during this project, review of archival maps suggest that the intersection may lie slightly to the east below the sidewalk on Fredericksburg Road. The construction of this segment of the Upper Labor suggests the possibility of a stone aqueduct at the intersection (Cox 2005). The portion of the site documented here appears to be intact and offers insight into the construction methods and long-term use of San Antonio's acequia system. CAR recommends that the section of the Upper Labor Acequia (41BX1273) documented here is eligible as a SAL. CAR further recommends that adverse impacts to the site should be avoided. CAR recommends that the grading and construction of the parking area, which will be above the level of the acequia, should be allowed to proceed with the presence of an archaeological monitor. However, should buried cultural features be encountered during construction, work in the immediate area should cease, and the THC and the COSA-OHP should be consulted on additional actions that may be necessary to protect the cultural remains. Both the THC and COSA-OHP concurred with these recommendations. However, during the review of this draft report by the THC and COSA-OHP, CAR was informed that VIA-MTA no longer plans to do any work in Project Area 1.

Feature 3 was documented within BHTs 4 and 5. It was identifiable by a change in the soil profile likely associated with the interior channel of the acequia and a smoothly cut limestone block with a layer of fist-sized cobbles below. All of BHT 4 was found to be to excavated within the acequia channel, so the entire BHT is included within the feature boundaries. The feature exhibits the north-south orientation of the San Pedro Acequia (41BX337) in this area (see Figures 1-3, 1-4, 2-1, and 2-2) and appears to follow the VIA-MTA property line. CAR was unable to define the boundaries of the feature to the north, west, and south because the feature extended beyond the boundaries of the trench. A small quantity of artifacts was collected from this feature, including one Galera sherd and some late historical material. In addition, Feature 4 is located within the interior channel of Feature 3. It is an area of white stained clay that may represent a dumping episode within the channel prior to its closing.

The San Pedro Acequia (41BX337) has previously been found eligible for the NRHP and designation as a SAL. The section documented within Project Area 2 appears to be intact and offers insight into the construction history and long-term use of San Antonio's acequia system due to confirmation of the acequia's alignment and evidence of modification over the course of its use. CAR recommends that this section of the San Pedro Acequia (41BX337) is eligible as a SAL. Adverse impacts to the site should be avoided. CAR further 
recommends that the grading and construction of the parking area, which will be above the level of the acequia, be allowed to proceed with the presence of an archaeological monitor. However, should buried cultural features be encountered during construction, work in the immediate area should cease and the THC and the COSA-OHP should be consulted on additional actions that may be necessary to protect the cultural remains. Both the THC and COSA-OHP concurred with these recommendations.
No artifacts were collected from Project Area 1, but several historic artifacts were collected from Project Area 2. These artifacts along with all records generated on this project are curated at the CAR facility as accession 2259. However, prior to the issuance of the concurrence by the THC and COSA-OHP, VIA-MTA paved Project Area 2 (712 W. Laurel Street) without notifying CAR. No monitor was present for the excavation and paving. CAR subsequently photographed the area (see Appendix B). 


\section{References Cited:}

Addis, B., and M. Bussell

2008 Chapter Two: Key Developments in the History of Concrete Construction and the Implications for Remediation and Repair. In Concrete: Building Pathology, edited by S. McDonald, pp. 15-105. Blackwell Science, Oxford.

Bexar County Deed Records

1877 V6:565 November 20, 1877. Plat of subdivision of lands belonging to Rosa P. Younger and Virginia A. Gillum.

Blair, W.F.

1950 The Biotic Provinces of Texas. Texas Journal of Science 1(2):93-117.

Buck, S.M.

1980 Yanaguana's Successors: The Story of the Canary Islanders' Immigration into Texas in the Eighteenth Century. R.M. Benavides, San Antonio. Originally published 1949, Naylor, San Antonio.

Chipman, D.E., and H.D. Joseph

2010 Spanish Texas, 1519-1821. Rev. ed. University of Texas Press, Austin.

City of San Antonio (COSA)

20095 Point Neighborhood Plan Update: Where It All Comes Together. City of San Antonio Planning and Development Services Department.

Collins, M.B.

2004 Archeology in Central Texas. In The Prehistory of Texas, edited by T.K. Perttula, pp. 205-265. Texas A\&M University Press, College Station.

Cox, I.W.

1986 Excavations of Portions of the San Pedro Acequia (41BX337) and a Search for the Arocha Acequia, San Antonio, Texas. Archaeological Survey Report, No. 161. Center for Archaeological Research, The University of Texas at San Antonio.

1993 Excavation of a Portion of the San Pedro Acequia (41BX337) VIA Metropolitan Transit System Parking Lot, San Antonio, Bexar County, Texas. Archaeological Survey Report, No. 219. Center for Archaeological Research, The University of Texas at San Antonio.

1995 Documentation of the San Pedro Acequia (41BX337), at Trevino Street, San Antonio, Texas. Archaeological Survey Report, No. 239. Center for Archaeological Research, The University of Texas at San Antonio.

1997 The Growth of San Antonio. In Archaeology at the Alamodome: Investigations of a San Antonio Neighborhood in Transition. Volume 1, Historical, Architectural, and Oral History Research, edited by A.A. Fox, M. Renner, and R.J. Hard, pp. 8-44. Archaeological Survey Report, No. 236. Center for Archaeological Research, The University of Texas at San Antonio.

2005 The Spanish Acequias of San Antonio. Maverick Publishing Company, San Antonio.

Cox, I.W., E.D. Johnson, and C.B. Bousman

1999 Excavations for the Upper Labor Dam Site, Brackenridge Park, San Antonio, Bexar County, Texas. Archaeological Survey Report, No. 268. Center for Archaeological Research, The University of Texas at San Antonio.

Cruz, G.R.

1988 Let There Be Towns: Spanish Municipal Origins in the American Southwest, 1610-1810. Texas A\&M University Press, College Station. 
de la Teja, J.F.

1991 Forgotten Founders: The Military Settlers of Eighteenth Century San Antonio de Bexar. In Tejano Origins in EighteenthCentury San Antonio, edited by G.E. Poyo and G.M. Hinajosa, pp. 27-41. University of Texas Press, Austin.

1995 San Antonio de Bexar: A Community on New Spain's Northern Frontier. University of New Mexico Press, Albuquerque.

Fontana, B.L., J.C. Greenleaf, C.W. Ferguson, R.A. Wright, and D. Frederick

1962 Johnny Ward’s Ranch: A Study in Historic Archaeology. Kiva 28(1/2):1-115.

Foster, W.C.

1998 The La Salle Expedition to Texas: The Journal of Henri Joutel 1664-1687. Texas State Historical Association, Austin.

Fox, A.

1978 Archaeological Investigations of Portions of the San Pedro and Alazan Acequias in San Antonio, Texas. Archaeological Survey Report, No. 49. Center for Archaeological Research, The University of Texas at San Antonio.

1979 A Survey of Archaeological, Architectural, and Historical Sites on the San Antonio River from Olmos Dam to South Alamo Street and on San Pedro Creek from San Pedro Park to Guadalupe Street. Archaeological Survey Report, No. 80. Center for Archaeological Research, The University of Texas at San Antonio.

Fox, A., and I.W. Cox

1988 Archaeological Monitoring of the Ashby Street Drainage Project, San Antonio, Bexar County, Texas. Archaeological Survey Report, No. 176. Center for Archaeological Research, The University of Texas at San Antonio.

Fox, A., and K.M. Ulrich

2008 A Guide to Ceramics from Spanish Colonial Sites in Texas. Special Report, No. 33. Center for Archaeological Research, The University of Texas at San Antonio.

Freisleben, G.

1875 Plat of Lands in the Northern Portion of San Antonio, Texas. Copy on file, Center for Archaeological Research, The University of Texas at San Antonio. Original at University of North Texas Libraries.

Frkuska, A.J.

1981 Archaeological Investigations at the San Pedro Acequia, San Antonio, Texas. Archaeological Survey Report, No. 103. Center for Archaeological Research, The University of Texas at San Antonio.

Habig, M.A.

1968 The Alamo Chain of Missions: A History of San Antonio's Five Old Missions. Franciscan Herald Press, Publishers of Franciscan Literature, Chicago.

Hanson, C.

2016 Archaeological Investigations for the Main Plaza Redevelopment Project, San Antonio, Bexar County, Texas. Atkins, Austin.

Heusinger, E.W.

1951 A Chronology of Events in San Antonio: Being a Concise History of the City Year by Year, From the Beginning of its Establishment to the End of the First Half of the Twentieth Century. Standard Printing, San Antonio.

Houk, B.A.

1999 Archaeological Survey and Testing in San Pedro Park (41BX19), San Antonio, Texas. Archaeological Survey Report, No. 289. Center for Archaeological Research, The University of Texas at San Antonio.

Ivey, J.E., and C.M.M McKenzie

2019 Archival Assessment of New City Block 114 in La Villita, San Antonio, Bexar County, Texas. On file, Center for Archaeological Research, The University of Texas at San Antonio. 
Kemp, L., J.E. Zapata, C.M.M. McKenzie, M. Pfeiffer, and R. Curilla

2019 Archaeological Monitoring of the Downtown Street Reconstruction Project at North Main Avenue and Soledad Street and the State Antiquities Landmark Testing of 41BX2164 and 41BX2170, San Antonio, Bexar County, Texas. Archaeological Report, No. 462. Center for Archaeological Research, The University of Texas at San Antonio.

Kenmotsu, N.A., and J.W. Arnn

2012 The Toyah Phase and the Ethnohistoric Record: A Case for Population Aggregation. In The Toyah Phase of Central Texas: Late Prehistoric Economic and Social Processes, edited by N.A. Kenmotsu and D.K. Boyd, pp. 19-43. Texas A\&M University Press, College Station.

Labadie, J.H.

1987 An Archaeological and Historical Assessment of the Vista Verde South Project, San Antonio, Texas. Archaeological Survey Report, No. 156. Center for Archaeological Research, The University of Texas at San Antonio.

Lindsey, B.

2020 Historic Glass Bottle Identification and Information Website. Electronic document, https://sha.org/bottle, accessed March 12, 2020.

Long, C.

2017 Bexar County. Handbook of Texas Online. Texas State Historical Association. Electronic document, https://tshaonline. org/handbook/online/articles/hcb07, accessed February 9, 2020.

Mauldin, R., S. Smith, S. Wigley, A. Figueroa, and C. McKenzie

2015 Archaeological Investigations within San Pedro Springs Park (41BX19), San Antonio, Bexar County, Texas. Archaeological Report, No. 443. Center for Archaeological Research, The University of Texas at San Antonio.

McKenzie, C.M.M.

2015 Investigations on the Site of Wohlfarth's Mercantile and the Search for the Arocha Acequia, San Antonio, Bexar County, Texas. Technical Report, No. 63. Center for Archaeological Research, The University of Texas at San Antonio.

2017 Archaeological Investigations of the Alamo Dam and the Upper Labor Dam, Brackenridge Park, San Antonio, Bexar County, Texas. Archaeological Report, No. 444. Center for Archaeological Research, The University of Texas at San Antonio.

McKenzie, C.M., L. Martinez, and R. Mauldin

2016 Archaeological Monitoring and Test Excavations at the 1722 Presidio San Antonio de Bexar (Plaza de Armas Buildings). Archaeological Report, No. 445.Center for Archaeological Research, The University of Texas at San Antonio.

Meissner, B.A.

2000 An Archaeological Assessment of San Pedro Park (41BX19), San Antonio, Texas. Archaeological Survey Report, No. 269. Center for Archaeological Research, The University of Texas at San Antonio.

National Park Service (NPS)

1980 Ximenes Chapel. National Register of Historic Places. Electronic document, https:/npgallery.nps.gov/NRHP/ AssetDetail?assetID=6d2a9100-b77c-46e3-83f1-db40712e8e37, accessed February 26, 2020.

2011 Brackenridge Park, San Antonio, Bexar County, Texas. National Register of Historic Places Registration Form. United States Department of the Interior.

2020 NP Gallery Digital Asset. Electronic document, https://npgallery.nps.gov/nrhp, accessed March 13, 2020.

Natural Resources Conservation Service (NRCS)

2020 Web Soil Survey. United States Department of Agriculture. Electronic document, https://websoilsurvey.sc.egov.usda. gov/App/HomePage.htm, accessed February 9, 2020. 
Nickels, D.L., and I.W. Cox

1996 An Archaeological Assessment of the Alazán Ditch (41BX620) in the Five Points Area of San Antonio, Bexar County, Texas. Archaeological Survey Report, No. 253. Center for Archaeological Research, The University of Texas at San Antonio.

Petersen, J.F.

2001 San Antonio: An Environmental Crossroads on the Texas Spring Line. In On the Border: an Environmental History of San Antonio, edited by C. Miller, pp.17-41. University of Pittsburgh Press, Pennsylvania.

Poyo, G.E.

1991 The Canary Island Immigrants of San Antonio: From Ethnic Exclusivity to Community in Eighteenth-Century Bexar. In Tejano Origins in Eighteenth-Century San Antonio, edited by G.E. Poyo and G.M. Hinajosa, pp. 41-61. University of Texas Press, Austin.

Ramsdell, C.

1976 San Antonio: A Historical and Pictorial Guide. University of Texas Press, Austin.

Sanborn Map Company (Sanborn)

1904 Sanborn Fire Insurance Map, San Antonio Texas. Vol. 2, Sheet 79. New York, New York

1911 Sanborn Fire Insurance Map, San Antonio, Texas. Vol. 1, Sheet 45. New York, New York.

Snell, L.M., and B.G. Snell

2002 Oldest Concrete Street in the United States. Concrete International (March 2002):72-74.

Texas Historical Commission (THC)

2006 A Steward's Illustrated Key to Historic Ceramics. Rev. ed. Texas Historical Commission, Austin.

2020 Texas Archaeological Sites Atlas. Electronic document, https://atlas.thc.state.tx.us/, accessed February 9, 2020.

Texas State Historical Association (TSHA)

2010 San Pedro Creek (Bexar County). Handbook of Texas Online. Texas State Historical Association. Electronic document, http://www.tshaonline.org/handbook/online/articles/rbs55, accessed February 9, 2020.

Thomas, A., and C.M.M. McKenzie

2019 Archaeological Monitoring for Frio Street Utility Improvements from Houston Street to Cesar Chavez Boulevard, San Antonio, Bexar County, Texas. Archaeological Report, No. 460. Center for Archaeological Research, The University of Texas at San Antonio.

Uecker, H.G.

1991 Archival and Historical Research for the San Pedro Creek Channel Improvement Project: The 1989-1990 Investigations. Archaeological Survey Report, No. 199. Center for Archaeological Research, The University of Texas at San Antonio.

Valdez, F., Jr., and J. Eaton

1979 Preliminary Archaeological Investigations of Part of the San Pedro Acequia, San Antonio, Texas. Archaeological Survey Report, No. 85. Center for Archaeological Research, The University of Texas at San Antonio.

Wooster, R.A.

2018 Civil War. Handbook of Texas Online. Texas State Historical Association. Electronic document, https://tshaonline.org/ handbook/online/articles/qdc02, accessed March 18, 2019.

Zapata, J.E., and C.M.M McKenzie

2017 Archaeological Monitoring and Investigations for the Installation of a Compressed Natural Gas Line for the VIA Metropolitan Transit Authority, San Antonio, Bexar County, Texas. Technical Report, No. 69. Center for Archaeological Research, The University of Texas at San Antonio. 
Zapata, J.E., and B.A. Meissner

2003 San Pedro Springs Park Improvements: Archaeological Testing and Monitoring at 41BX19, San Antonio, Bexar County, Texas. Archaeological Survey Report, No. 331. Center for Archaeological Research, The University of Texas at San Antonio. 
This page intentionally left blank. 


\section{Appendix A: \\ Photographic Documentation of Selected Features and Artifacts}


This page intentionally left blank. 


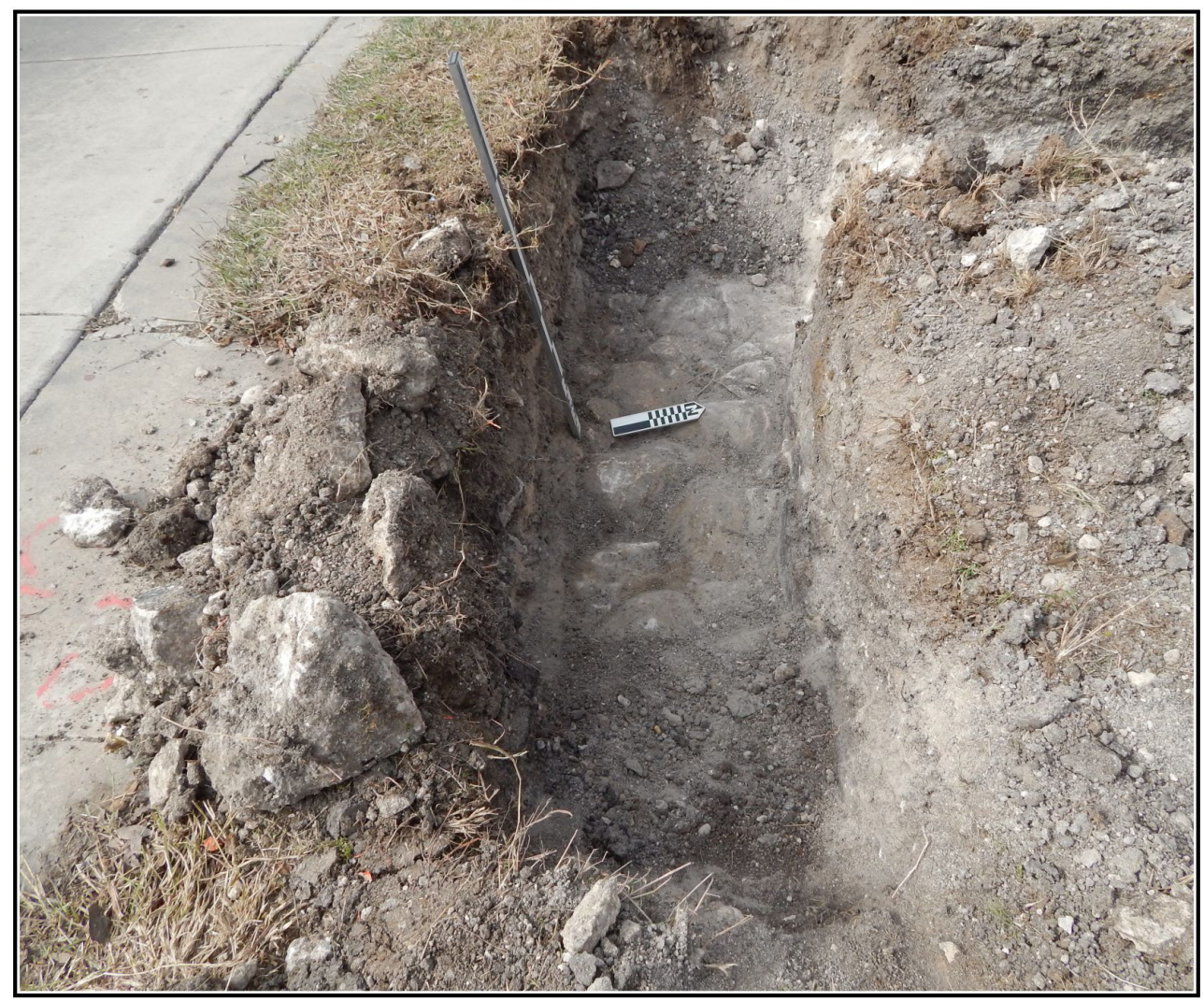

Figure A-1. Feature 1, floor, in BHT 1.

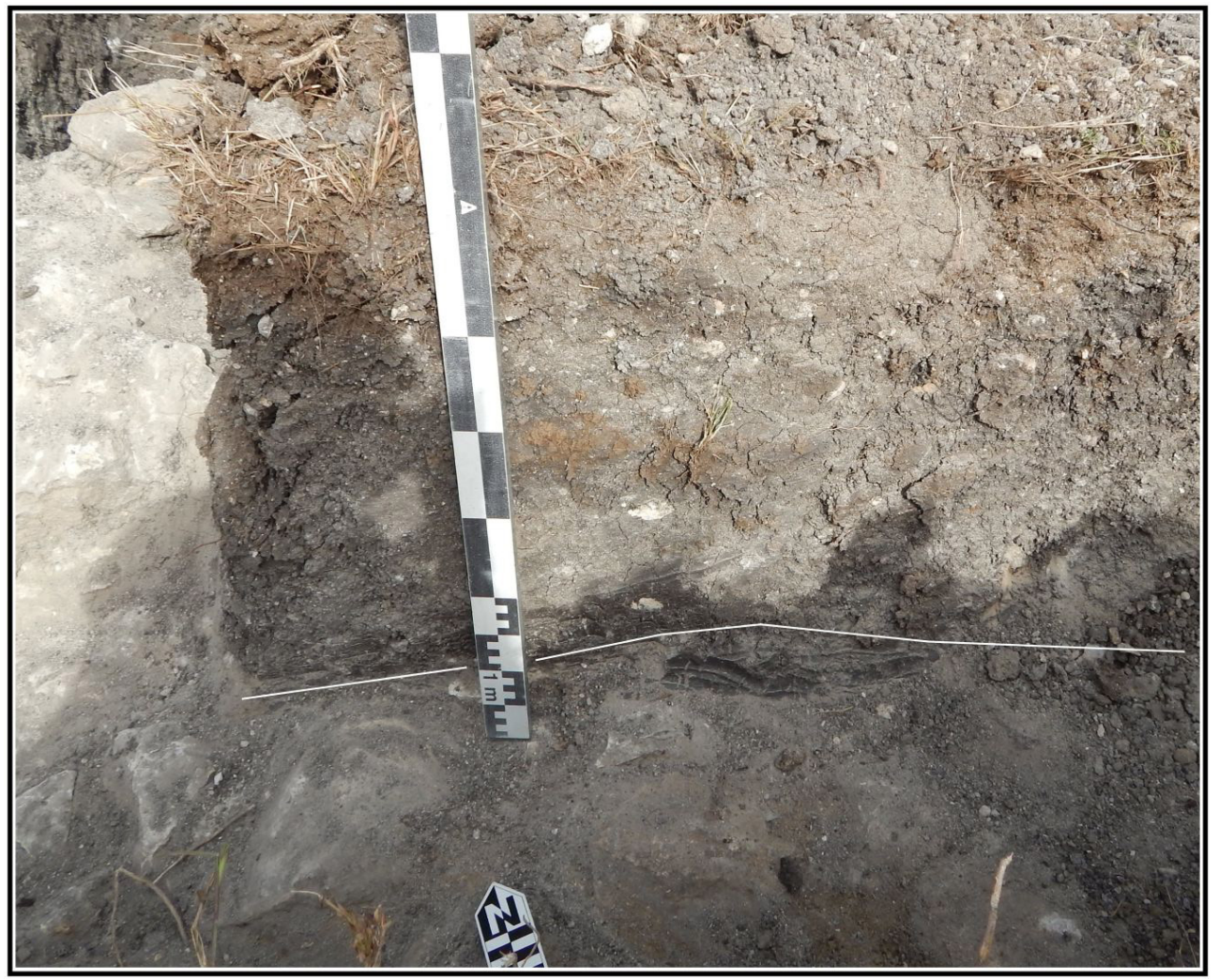

Figure A-2. North profile of BHT 1, Feature 1 to the left and foreground. Solid white line demarcates trench wall from floor. 


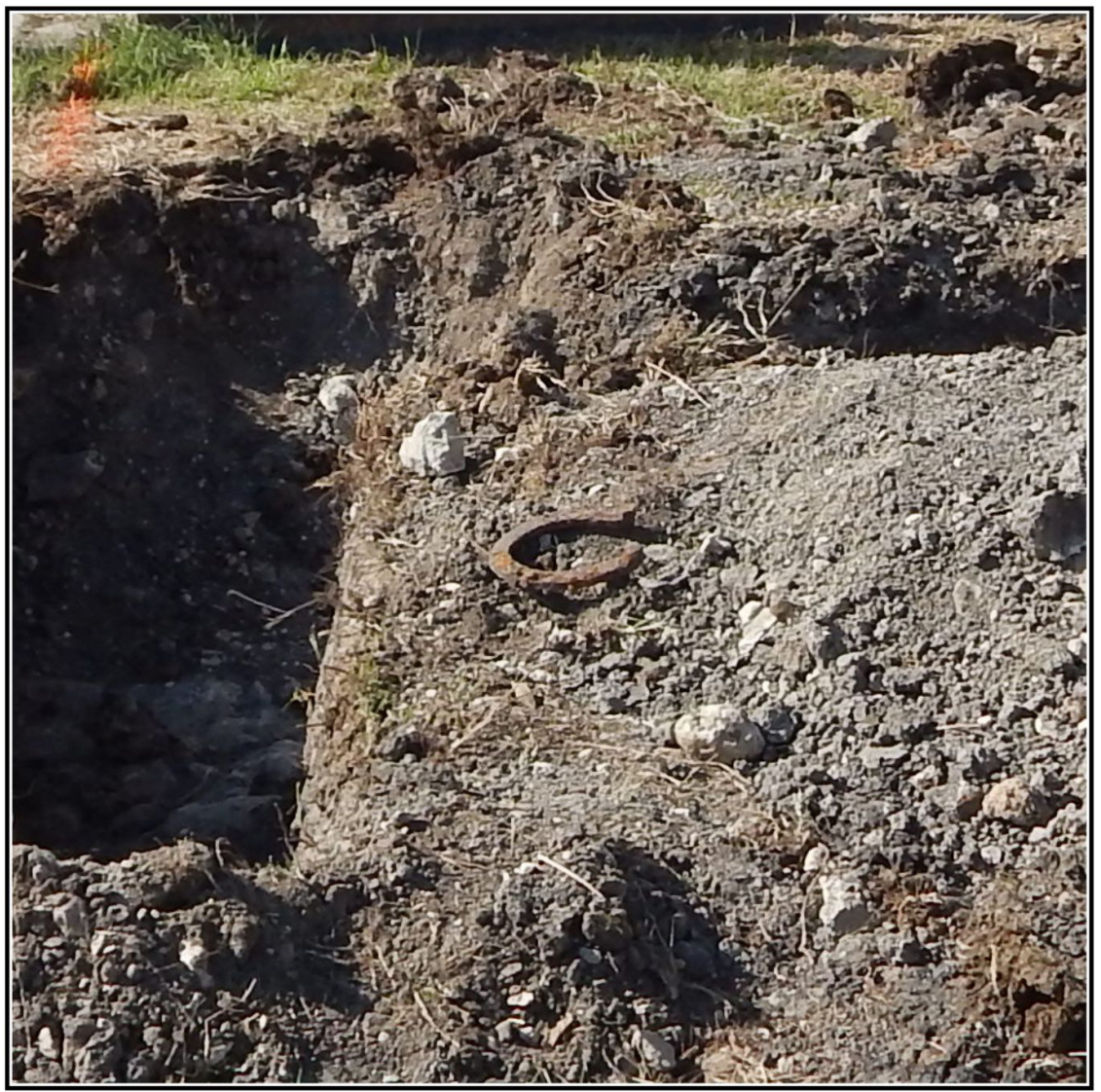

Figure A-3. Ox or mule shoe in backdirt of BHT 3. Not collected.

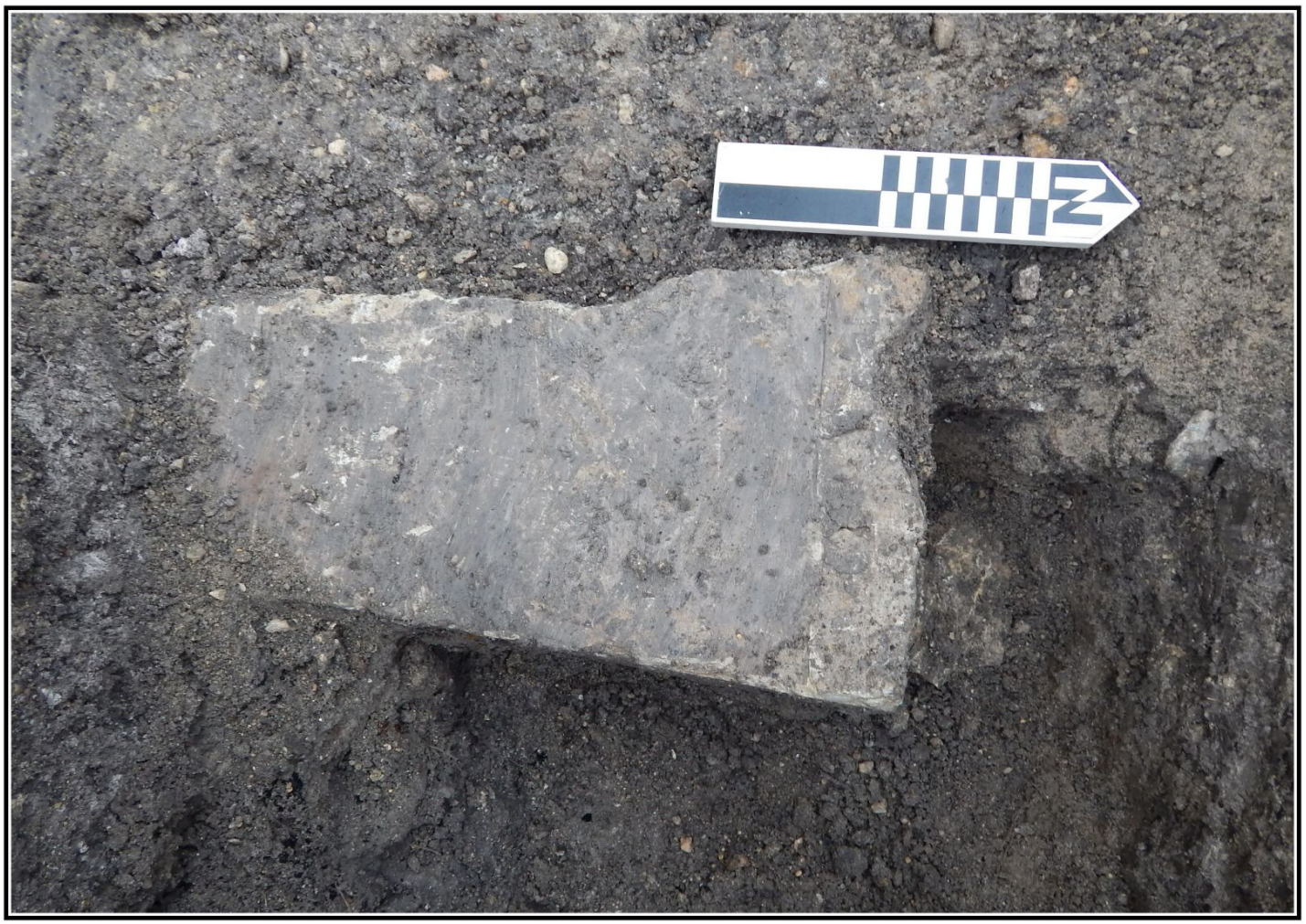

Figure A-4. Limestone block in Feature 3. 


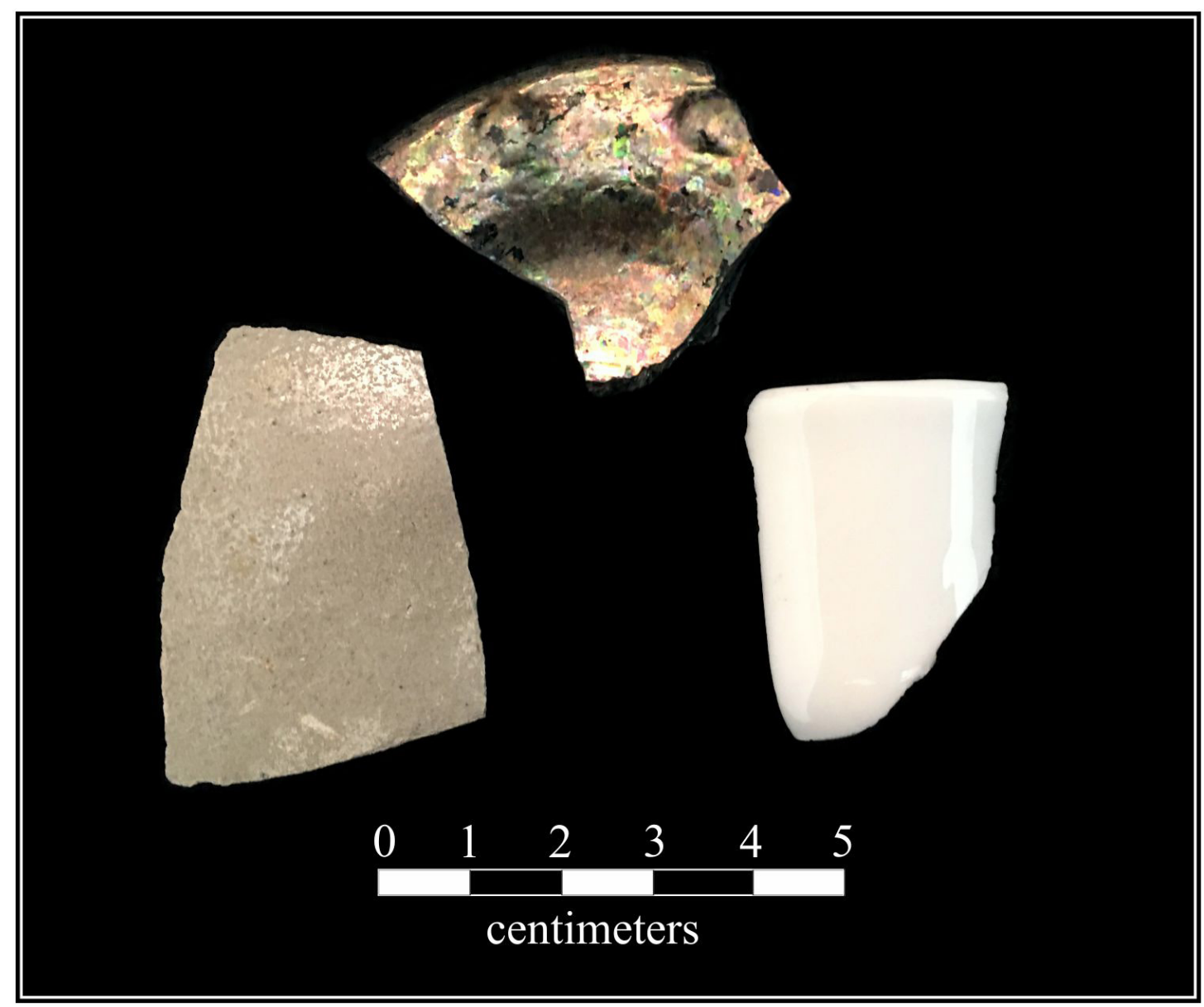

Figure A-5. Brown bottle base (top), stoneware sherd (left) and European Porcelain rim (right) from BHT 4 backdirt. See Table 4-1.

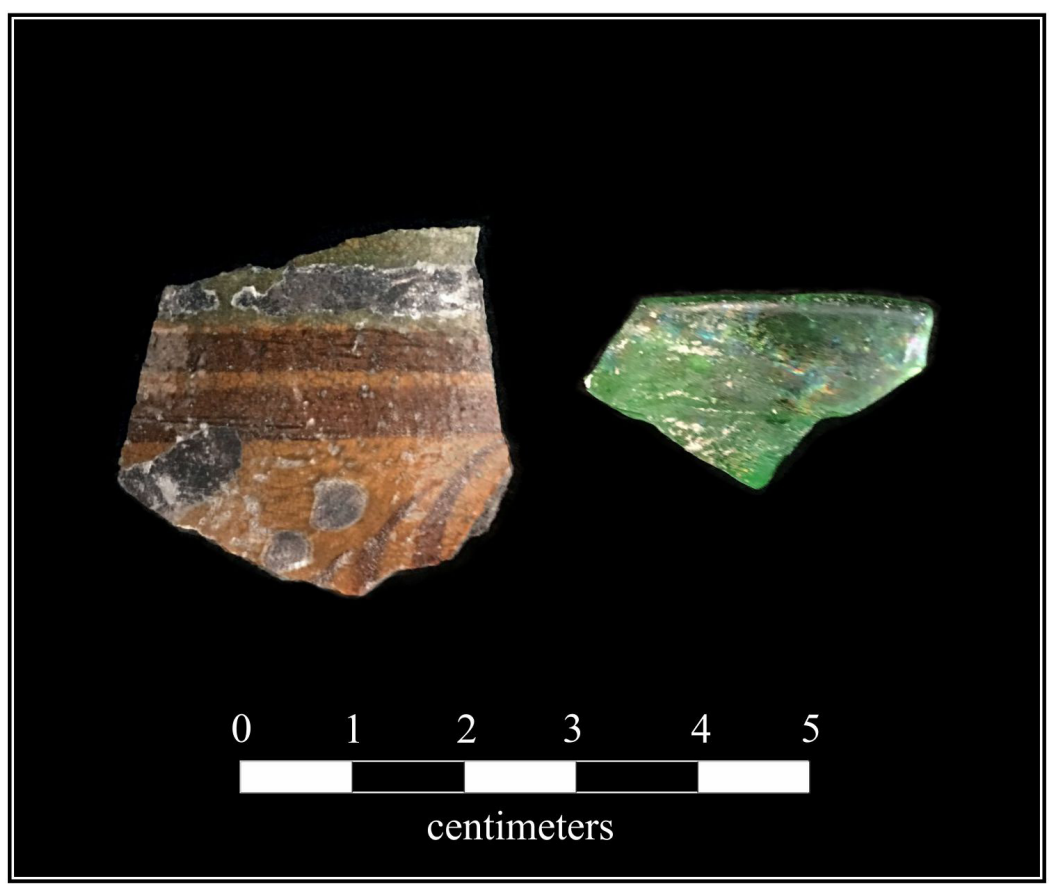

Figure A-6. Galera body sherd (left) and green glass rim from BHT 5 backdirt. See Table 4-1. 


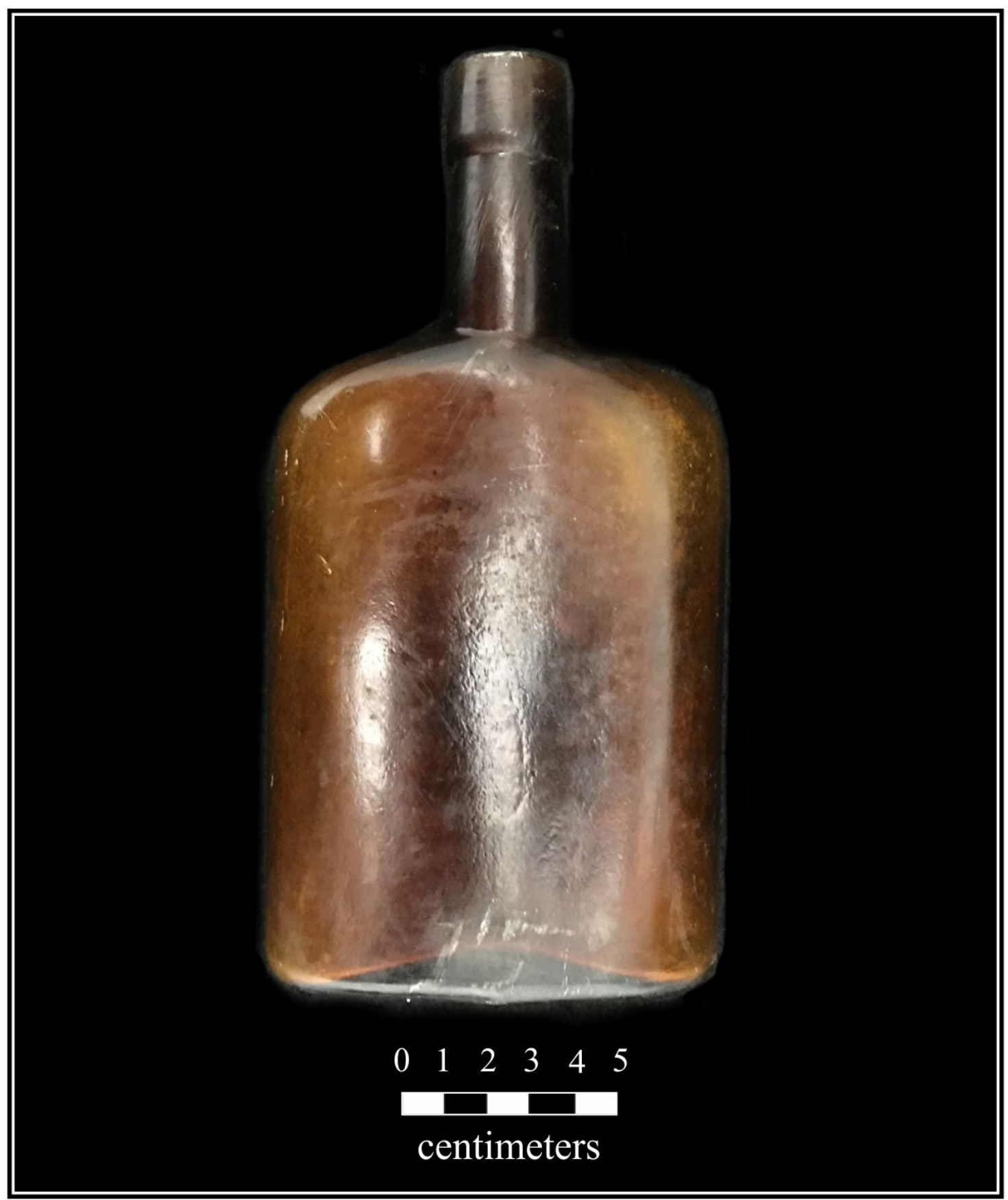

Figure A-7. Bottle from BHT 4 collected at $105 \mathrm{~cm}$ below the surface. See Table 4-1. 


\section{Appendix B:}

\section{Photographic Documentation of Project Area 2}


This page intentionally left blank. 


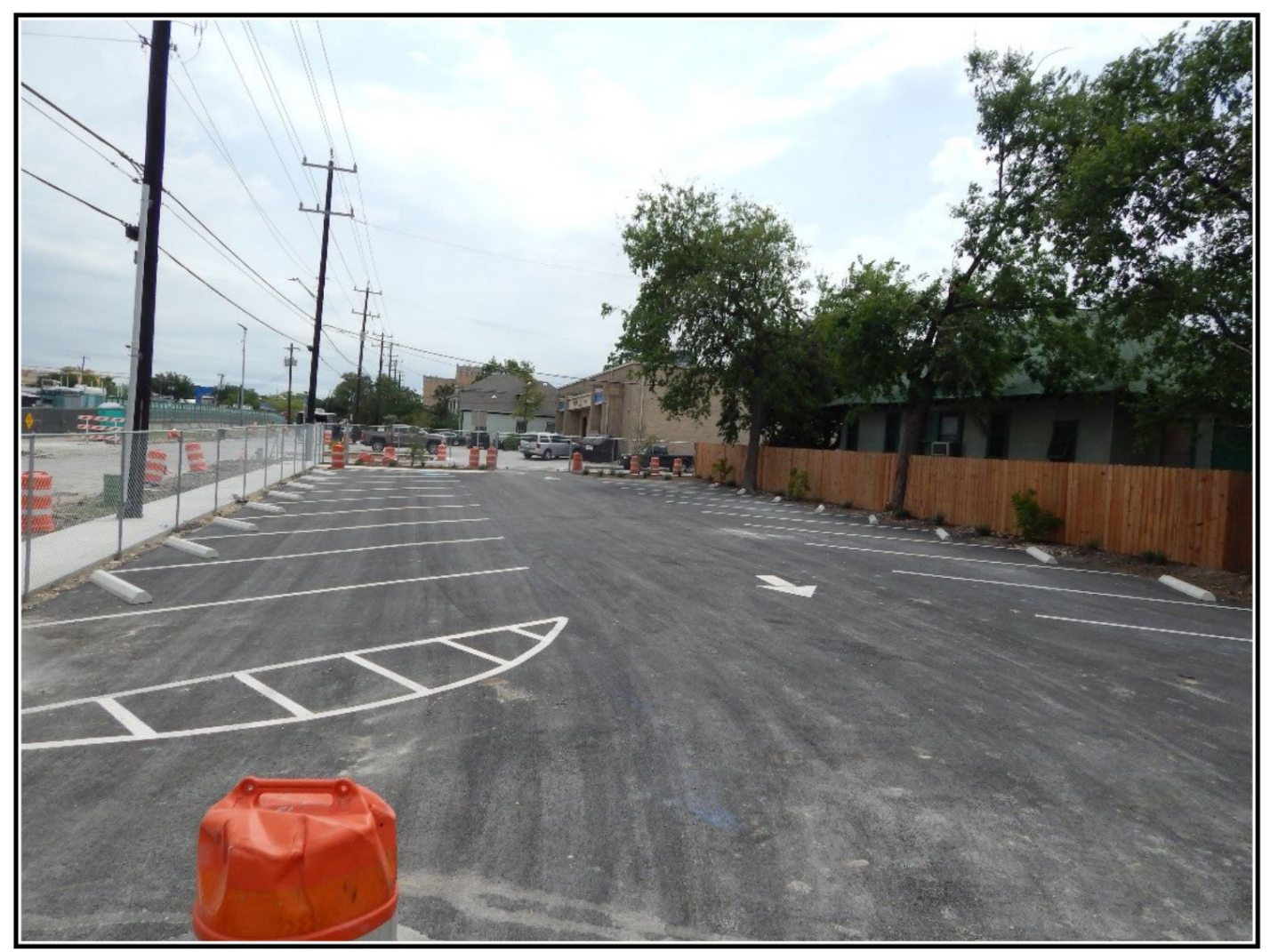

Figure B-1. Project Area 2, looking east.

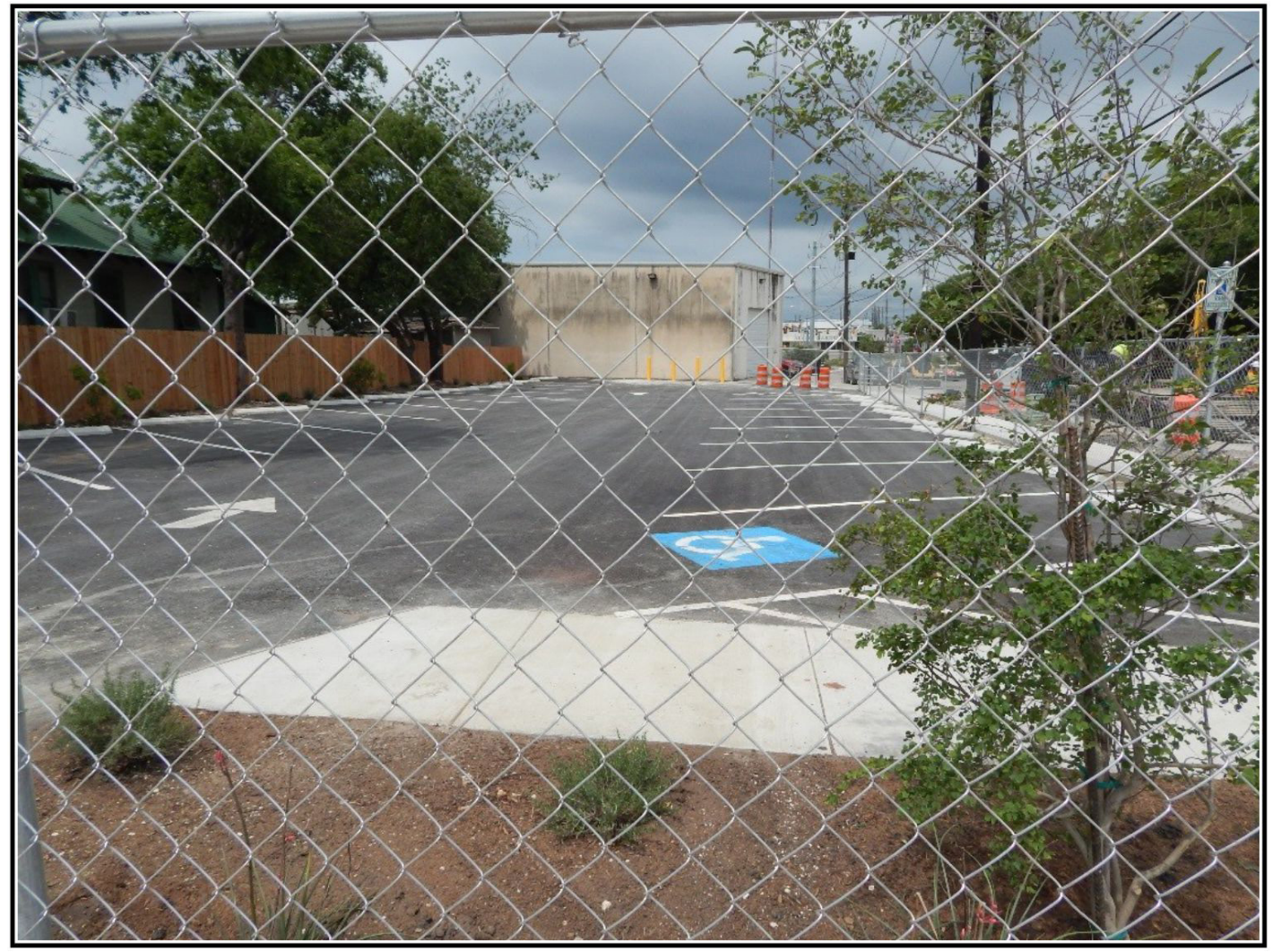

Figure B-2. Project Area 2, looking west. 